


\section{Grenzeloze 8RHK}

Werkdocument Preverkenning NPLG

L.L. de Rooij, J.J.L. Sluijsmans

Wageningen Environmental Research

Dit onderzoek is uitgevoerd door Wageningen Environmental Research en gesubsidieerd door het ministerie van Landbouw, Natuur en Voedselkwaliteit, in het kader van het Beleidsondersteunend onderzoekthema 'Ecologische basiskwaliteit Land' (projectnummer BO-43-021.01-035).

Wageningen Environmental Research

Wageningen, juli 2021

Gereviewd door:

P. Boone, strategisch landschapsarchitect, Applied Spatial Research

Akkoord voor publicatie:

C.J. van As, teamleider van Regionale Ontwikkeling en Ruimtegebruik 
Rooij, L.L. de, Sluijsmans, J., 2021. Grenzeloze 8RHK -Werkdocument Preverkenning NPLG. Wageningen, Wageningen Environmental Research

In het kader van het vorm te geven Nationaal Programma Landelijk Gebied is door Wageningen Environmental Research samen met Rijk, provincie en de regio 8RHK een preverkenning uitgevoerd. De preverkenning heeft als doel om een basis te leggen voor een gedeelde aanpak, waarbij inzicht in de samenhang en complexiteit van de opgaven én het natuurlijk systeem centraal staan. De preverkenning laat zien dat een gedeeld begrip van het natuurlijk systeem en de relaties, dwarsverbanden en ruimtelijke vertaling van de transities en opgaven het gezamenlijk vertrekpunt moet zijn. In een mogelijk gezamenlijk vervolgproces kan hier nader invulling aan worden gegeven.

Trefwoorden: integrale planning, gebiedsgerichte aanpak, natuurlijk systeem, NOVI, NPLG

Dit rapport is gratis te downloaden van https://doi.org/10.18174/550225.

Wageningen Environmental Research verstrekt geen gedrukte exemplaren van rapporten.

\section{(c) $\stackrel{\mathrm{is}}{(1)(8)}$}

(C) 2021 Wageningen Environmental Research (instituut binnen de rechtspersoon Stichting Wageningen Research), Postbus 47, 6700 AA Wageningen, T 03174807 00, www.wur.nl/environmental-research. Wageningen Environmental Research is onderdeel van Wageningen University \& Research.

- Overname, verveelvoudiging of openbaarmaking van deze uitgave is toegestaan mits met duidelijke bronvermelding.

- Overname, verveelvoudiging of openbaarmaking is niet toegestaan voor commerciële doeleinden en/of geldelijk gewin.

- Overname, verveelvoudiging of openbaarmaking is niet toegestaan voor die gedeelten van deze uitgave waarvan duidelijk is dat de auteursrechten liggen bij derden en/of zijn voorbehouden.

Wageningen Environmental Research aanvaardt geen aansprakelijkheid voor eventuele schade voortvloeiend uit het gebruik van de resultaten van dit onderzoek of de toepassing van de adviezen.

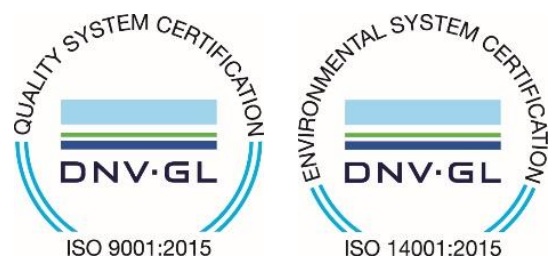

Wageningen Environmental Research werkt sinds 2003 met een ISO 9001 gecertificeerd kwaliteitsmanagementsysteem. In 2006 heeft Wageningen Environmental Research een milieuzorgsysteem geïmplementeerd, gecertificeerd volgens de norm ISO 14001.

Wageningen Environmental Research geeft via ISO 26000 invulling aan haar maatschappelijke verantwoordelijkheid.

Wageningen Environmental Research Rapport ।

Foto omslag: Solar landschapspark De Kwekerij. De inrichting van het terrein van dit zonnepark is ontworpen vanuit natuur en ecologie, en is illustratief voor het integreren van allerlei functies en opgaves. (Foto: Alex Schotman 2019) 


\section{Inhoud}

$\begin{array}{ll}\text { Verantwoording } & \mathbf{5}\end{array}$

$\begin{array}{ll}\text { Samenvatting } & 7\end{array}$

1

Inleiding

Veelvoud, verscheidenheid en verrassend verschillend

2.1 Veel en verscheiden

Urgenties en opgaven $\quad 19$

2.2 Stapeling en balans

2.3 Doorwerking en verbanden

2.4 Begrenzing en gemeenschappelijke basis

Ruimtelijke vertaling en projectie $\quad 21$

2.5 Data en informatie

2.6 Definities en taal

2.7 Reflectie

3.1 Gedeelde en gedragen samenbindende visie op basis van gedeeld begrip natuurlijk systeem

Aanzet kenschets De Grenzeloze 8RHK

3.2 Oorzaak-gevolg analyse

3.3 Integraal (wat moet) en sectoraal (wat kan)

Literatuur

Bijlage 1 Geraadpleegde analyses, plannen en processen 



\section{Verantwoording}

Rapport: Grenzeloze 8RHK -preverkenning NPLG

Projectnummer: 5200046859

Wageningen Environmental Research (WENR) hecht grote waarde aan de kwaliteit van zijn eindproducten. Een review van de rapporten op wetenschappelijke kwaliteit door een referent maakt standaard onderdeel uit van ons kwaliteitsbeleid.

Akkoord Referent die het rapport heeft beoordeeld,

functie: Strategisch landschapsarchitect, Applied Spatial Research

naam: $\quad$ P. Boone

datum: 29 juli 2021

Akkoord teamleider voor de inhoud,

naam: C.J. van As

datum: $\quad 23$ juli 2021 


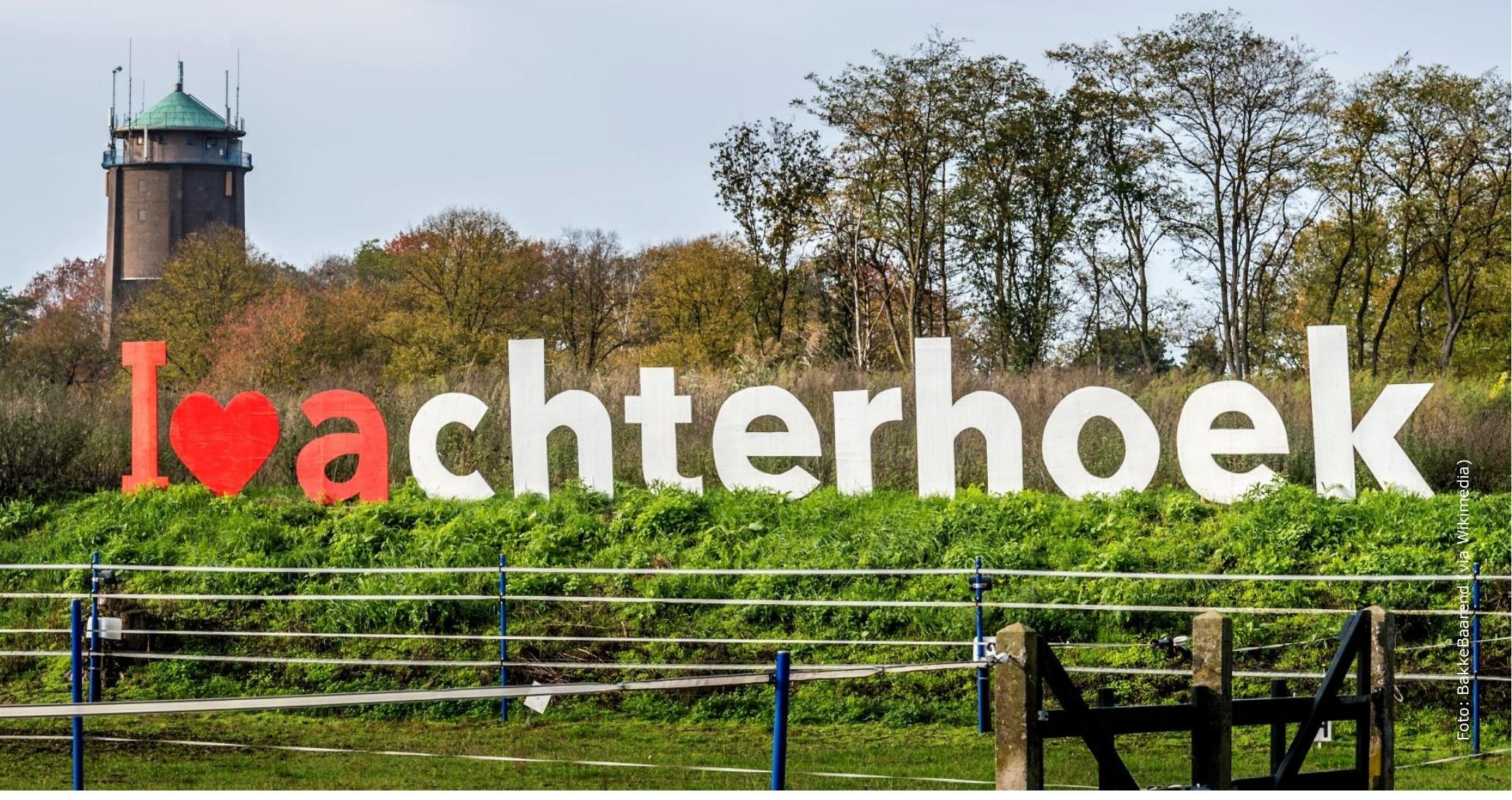




\section{Samenvatting}

In 2020 is de Nationale Omgevingsvisie uitgebracht. Aanvullende daarop zijn door de minister nieuwe richtinggevende keuzen voorgesteld, waaronder het vormgeven van een Nationaal Programma Landelijk Gebied. Centraal daarbij staan het in samenhang oppakken van de opgaven waar Nederland voor staat, het ontwikkelpotentieel van heel Nederland beter te benutten en een gebiedsgerichte aanpak -samen met de regio. Hoe deze samenhang echter tot stand te brengen, vorm te geven en het juiste instrumentarium en handelingsperspectieven daaraan te koppelen, vergt een gezamenlijke zoektocht.

De regio Achterhoek is een regio die hoog scoort op de brede welvaart, maar ook grote uitdagingen en opgaven kent om deze brede welvaart te bestendigen en door te ontwikkelen. Nadrukkelijk is de regio ook op zoek naar een betere positionering en afstemming tussen de opgaven, regio en bredere context. Daarin is de regio al zeer actief met brede ambities en volop energie.

Dit project heeft als overkoepelend doel om een basis te leggen voor het NPLG om te komen tot een samenhang in opgaven en versnelling in uitvoering van transities en ambities door het gezamenlijk ontwikkelen van een methodiek, zowel inhoudelijk, procesmatig en instrumenteel.

Deze pre-verkenning heeft als specifiek doel om het benodigde gedeelde overzicht te verkrijgen, dat als basis voor het verdere lerende proces kan dienen.

Om deze basis te leggen zijn er vier centrale vragen gesteld:

- Op welke wijze kunnen we overzicht verkrijgen en behouden in de complexiteit van opgaven, ambities en (ruimtelijke) transities om samenhang in visie en uitvoering te bewerkstellingen?

- Welke methodiek en instrumentarium kunnen we vormgeven en aanpassen om dit tot samenhang en versnelling te komen?

- Waar schittert het en waar schuurt het?

- Welke rol speelt het natuurlijk systeem daarin?

In dit werkdocument nemen wij u mee in dit gezamenlijke zoekproces, de complexiteit en de daaruit volgende inzichten en adviezen. Wij hebben er bewust voor gekozen om dit rapport niet als eindrapport of wetenschappelijk rapport aan te merken, maar als werkdocument. Immers, het geeft de eerste conclusies van een gezamenlijke zoektocht en is de opmaat naar verdere uitwerking en verdieping met de NPLG-werkgroep.

Overzicht en inzicht in complexiteit van opgaven, ambities en transities

In de beginfase van de pre-verkenning is getracht een zo goed mogelijk beeld te krijgen van alle relevant beleidsplannen, ambities en plannen op zowel bovenregionaal en regionaal niveau om zo het overzicht en inzicht te krijgen in de complexiteit van de opgaven, ambities en transities.

Daarin constateren we:

- Er zijn te veel plannen $(100+)$ om nog tot overzicht en inzicht te komen.

- De plannen tonen een te grote diversiteit in zowel benadering (thematiek), begrenzing (schaal), (gebieds)indelingen en (kaart)uitwerkingen.

- Data is volop voorhanden, maar resulteert niet vanzelfsprekend tot overzicht en inzicht.

- De data leidt niet standaard tot informatie. En is in veel gevallen niet gekoppeld aan heldere verhaallijnen ${ }^{1}$. Daarmee is dit niet direct bruikbaar op bestuursniveau of voor participatieve gebiedsprocessen.

\footnotetext{
1 Verhaallijnen of in het Engels 'narratives', komen voort uit het samengaan van 'weten' en 'vertellen'. Een verhaallijn wordt geconstrueerd met een duidelijke structuur waarin alle aspecten en causale verbanden op een logische, navolgbare wijze worden samengebracht. Als verhalen met een duidelijk doel worden opgebouwd, kunnen ze als strategische verhaallijnen worden aangemerkt. Een verhaal kan meerdere verhaallijnen bevatten.
} 
- De belangrijkste inzichten uit de analyse zijn:

- Een gemeenschappelijke basis of vertrekpunt ontbreekt

De doorwerking en verbanden tussen plannen en processen zijn minimaal.

$\mathrm{Er}$ is sprake van een stapeling van plannen en disbalans tussen de thema's

Data leidt niet vanzelfsprekend tot informatie en verhaallijnen.

De semantiek en definities lopen sterk uiteen.

\section{Het natuurlijk systeem}

Er zijn een aantal majeure transities van belang, die uiteindelijk ook duidelijk relaties met elkaar zouden moeten hebben en bovenal in hetzelfde gebied een plek moeten vinden en daarmee ook fysiek raken. Centraal daarin staan wel de draagkracht van het natuurlijk systeem en een bredere kijk op economie en welvaart. De majeure transities zijn:

- klimaatmitigatie en -adaptatie

voedseltransitie

circulaire economie

- brede welzijn en inclusieve samenleving

Het natuurlijk systeem en een gedeeld begrip daarvan, kan volgens ons dus een sterke, gezamenlijke basis vormen. De diverse transities hangen nauw samen met het functioneren van het natuurlijk systeem en de invloed daarop. Het natuurlijke systeem kan daarmee ook de verbinding leggen tussen de diverse opgaven en transities.

\section{Schitteren en schuren}

Wellicht de crux van de analyse: de doorwerking van de verschillende beleidsplannen en ambities lijkt beperkt te zijn. Dit hangt naar verwachting ook samen met de wijze waarop bovenstaande is georganiseerd en tot uitdrukking komt. Door het ontbreken van deze doorwerking en verbanden wordt de inhoudelijk vraag 'waar het schittert of schuurt' ook niet beantwoord, terwijl dit wel van wezenlijk belang is.

\section{Opmaat naar methodiek}

Om daadwerkelijk tot samenhang en versnelling te komen, stellen wij op basis van onze analyse een opzet voor een methodiek voor. Een methodiek voor het ontwikkelen van integrale gebiedsplanning met respect voor het natuurlijk systeem en waarin de vraag 'hoe doe je dat?' centraal staat.

Die methode bestaat uit de volgende elementen:

1. Ontwikkeling en verankering van een gedeelde en gedragen samenbindende visie, op basis van een gedeeld begrip van het natuurlijk systeem.

2. Oorzaak-gevolg analyse: hoe hangen de dingen met elkaar samen en op welk niveau?

3. Integraal (wat moet) en sectoraal (om tempo te maken).

4. Ter ondersteuning daarvan zijn (zichtbare) goede voorbeelden van belang. Het 'wiel zelf uitvinden' kost veel tijd, terwijl anderen het elders misschien al hebben uitgevonden. Hoe meer goede voorbeelden je kunt overnemen hoe meer tempo je kunt maken. Goede bewezen voorbeelden zou je toegankelijk kunnen maken vanuit een 'referentie bibliotheek'. Een nog te ontwikkelen (gebiedsgericht) datalab zou de methodiekontwikkeling met gebiedsspecifieke én op maat gemaakte generieke informatie kunnen ondersteunen

Deze elementen worden in dit werkdocument nader toegelicht. 
Handelingsperspectief en vervolg

Een dergelijke methode-ontwikkeling zal lastig binnen bestaande werkwijzen passen. Om de urgentie te onderschrijven, ontwikkelruimte te creëren en de ontwikkelde methodiek ook daadwerkelijk toe te gaan passen is een opdracht nodig van de gezamenlijke bestuurders. Het is belangrijk dat het proces begint bij het bestuurlijk ondersteunen van de gezamenlijkheid en de keuze voor het leidend maken van de natuurlijke processen.

Het verdient de aanbeveling een start te maken op basis van concrete casuïstiek met een gedeeld gevoel van urgentie. De droogteaanpak Achterhoek lijkt daarvoor zeer geschikt. Niet alleen vanwege de duidelijke verbinding tussen de korte termijn acties en de lange termijn strategie, maar omdat de klimaateffecten ook direct samenhangen met het natuurlijk systeem, én met de voedsel- en landbouwtransitie en het belang van biodiversiteit. $\mathrm{Er}$ is al hard gewerkt aan het gezamenlijk begrip van het basissysteem en door het uitwerken van een sterke oorzaak-gevolganalyse en duidelijke procesaanpak tussen integraal wat moet en sectoraal wat kan, kan dit dossier zeker verder gebracht worden en als goed voorbeeld dienen voor verder uitbouw, aanscherping en aanpassing van de voorgestelde methodiek. Deze methodiek zou dan breed in het land toepasbaar moeten zijn.

Wij dagen de partijen in het gebied dan ook uit om de lessen die getrokken zijn in deze preverkenning op te pakken en gezamenlijk verder te brengen. 


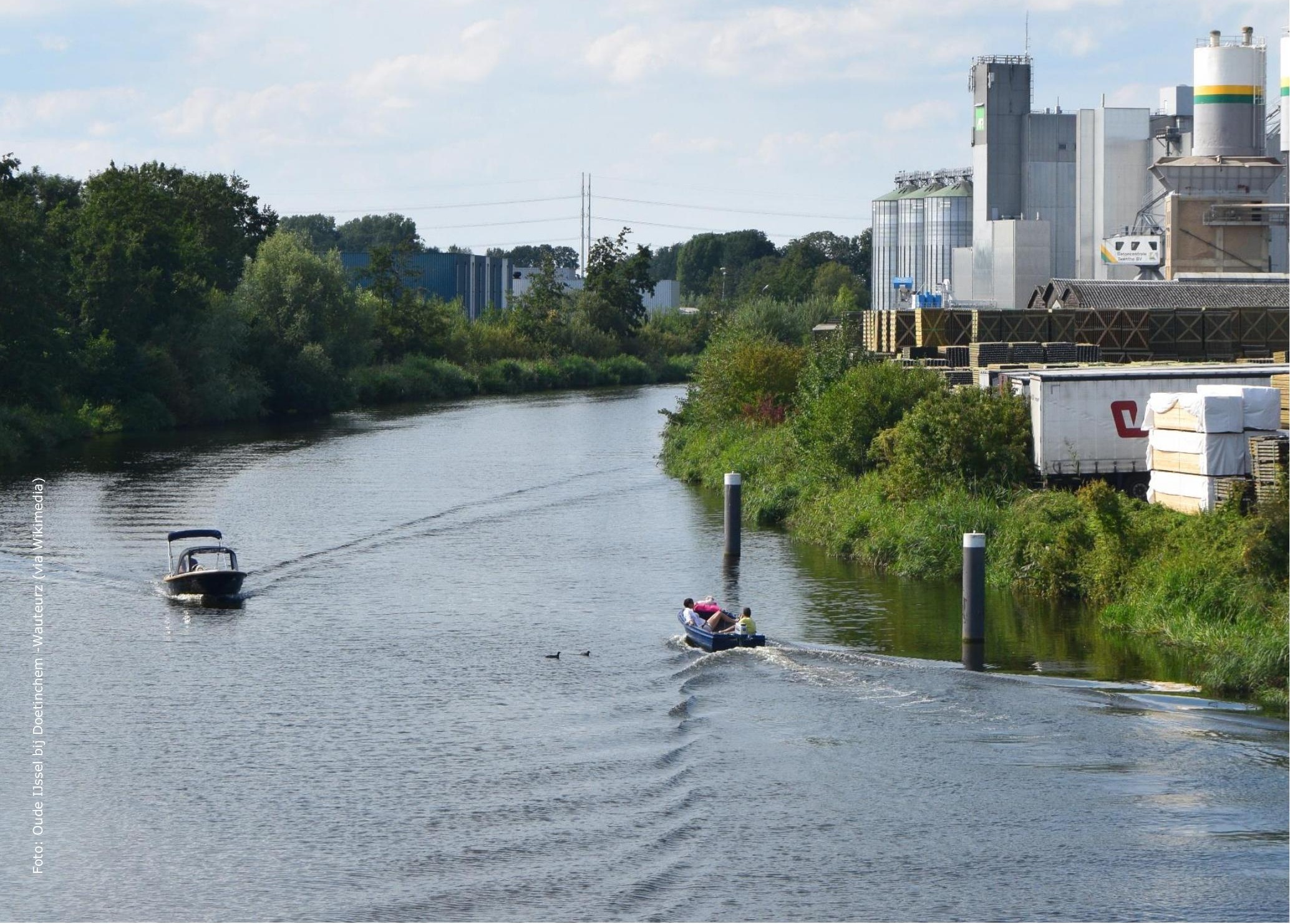




\section{$1 \quad$ Inleiding}

De regio Achterhoek is voor velen wellicht nog het kenmerkende agrarische landelijk gebied met rust, ruimte en een zeer karakteristiek landschap. De regio biedt echter nog zoveel meer: een regio met ambities, kansen en een boel energie. De regio Achterhoek scoort hoog op brede welvaart.

Brede welvaart

"Brede welvaart betreft de kwaliteit van leven in het hier en nu en de mate waarin deze al dan niet ten koste gaat van die van latere generaties en/of van die van mensen elders in de wereld" (CBS, 2020).

Het concept 'bruto binnenlands product' (bbp) per hoofd van bevolking wordt tot op heden nog overwegend gebruikt om de welvaart van een land, een regio en haar mensen te meten. Het is echter van belang te realiseren dat economische groei niet per definitie de welvaart bepaalt. Ook andere aspecten doen er toe; en wellicht doen deze er meer toe.

De brede welvaart beschouwd de welvaart dan ook in een breder perspectief, waarin een breed palet aan welvaartindicatoren als basis wordt genomen (welzijn, welvaart, gezondheid, arbeid en vrije tijd, wonen, samenleving, veiligheid en milieu). Daarnaast wordt bij brede welvaart vooral ook gekeken naar het economisch, natuurlijk, menselijk en sociaal kapitaal op de langere termijn. En tenslotte, wordt bezien welke effecten elders hun impact laten zien. Voor het vergroten van onze welvaart is het van belang niet eenzijdig naar een van de welvaartsdimensies te kijken, maar deze integraal te benaderen (Van Bavel, 2019).

Maar in de regio komen echter ook grote uitdagingen en opgaven samen, die noodzaken tot actie om ook in toekomst deze brede welvaart te bestendigen en door te ontwikkelen; denk daarbij aan de transitie van de landbouw, demografische ontwikkelingen en klimaatbestendigheid. De regio is reeds sterk op zoek naar herpositionering, profilering en agendering, maar bovenal naar de juiste afstemming tussen de opgaven, de regio en de bredere context. De Achterhoek heeft de ambitie gesteld te willen groeien in kwaliteit en de basis te leggen voor een sterker bloeiende en innovatieve economie in combinatie met een kwalitatief hoogwaardige, goed bereikbare en duurzame woon- en werkomgeving; in een grenzeloos perspectief. De regio is ambitieus en heeft de nodige initiatieven, activiteiten en samenwerkingsverbanden -zoals de 8RHK ambassadeurs- ontplooid. Desalniettemin, bestaat er grote behoefte om de diversiteit aan opgaven en ontwikkelingen samen te brengen en de samenhang in strategie te versterken.

Dit vraagt om een brede, integrale benadering vanuit alle overheden en betrokken partijen. De opmaat wordt gegeven voor een Nationale strategie voor landelijk gebied (Nationaal Programma Landelijk Gebied (NPLG)). Doel van dit Nationaal Programma is om "in nauwe samenspraak met decentrale overheden en betrokken partijen en sectoren een strategie op hoofdlijnen te schetsen, die richting geeft aan toekomstbestendige ontwikkeling van functies in het landelijk gebied, inclusief verstedelijking, verbetering van leefbaarheid, luchtkwaliteit en andere onderdelen van milieu, natuur en leefomgevingskwaliteit." Gekoerst wordt op een optimale en integrale planning van functies, in samenhang en met een lange termijn aanpak en duidelijke richtinggevende keuzen en prioriteiten als aanvulling op de richtinggevende keuzes uit de NOVI. Daarin wordt terecht gekozen voor een gebiedsgerichte aanpak: samen met de regio.

De basis hiervoor is een regionale aanpak, waarin alle partijen volwaardig betrokken zijn en gezamenlijk langs een gedeelde basis inzicht verkrijgen in de opgaven en de mogelijke samenhang en synergie daarbij. Hierbij wordt enerzijds gewerkt aan een methode en proces, waarin continuïteit en afstemming de basis leggen voor een daadwerkelijke integrale aanpak die de schalen, sectoren en stakeholders verbindt en verbonden houdt. 
In een preverkenning is voor het pioniersgebied de Achterhoek door Wageningen Environmental Research (Wageningen Universiteit \& Research) samen met de regiopartijen -de 8RHK ambassadeurs, provincie Gelderland en Waterschap Rijn en IJssel, alsmede de beide ministeries van Binnenlandse Zaken en Koninkrijksrelaties en Landbouw, Natuur en Voedselkwaliteit, zowel inhoudelijk als procesmatig verkend hoe deze aanpak ontwikkeld kan worden, de integrale inzichten verkregen kunnen worden en daarmee ook de noodzakelijke afstemming en stroomlijning verder vorm kan krijgen.

Het toekomstperspectief 'Naar een natuurlijkere toekomst voor Nederland in 2120' (WUR, 2019), waarin een eerste poging is gedaan om de brede opgaven ruimtelijk samen te brengen en waarin de natuurlijke basis en systemen een stevig fundament vormen, vormt daarbij een inspiratiebron. Een inspiratiebron die ook resoneert in de diverse adviezen die in 2020 en 2021 zijn uitgebracht, zowel over de toekomstige ruimtelijke strategie en planvorming in Nederland als meer gebiedsspecifieke uitwerkingen.

De belangrijkste elementen daarin zijn:

- het natuurlijk systeem aan de basis van de ruimtelijke en functionele planvorming

- $\quad$ integrale planvorming met duidelijke synergie tussen het natuurlijk systeem, het sociaalmaatschappelijke systeem en de economie

- $\quad$ het belang van een langetermijnperspectief en (sectorale) korte termijn handelingsperspectieven

- de gebiedsgerichte benadering

\section{Doel}

De preverkenning heeft als doel om een basis te leggen en inzichten te verkrijgen voor het Nationaal Programma Landelijk Gebied, waarbij de samenhang in de opgaven en versnelling in de uitvoering van transities en ambities centraal staan. Nadrukkelijk beoogt de preverkenning om bestuurlijke keuzen voor te leggen en vanuit de inhoud de dialoog te openen naar een sterkere samenhang en de verbanden en afhankelijkheden tussen de transities en de opgaven te versterken.

\section{Vraagstelling}

Om deze basis te leggen, de juiste inzichten te vergaren en de juiste dialoog te openen, zijn er in gezamenlijkheid met de NPLG werkgroep vier centrale vragen gesteld:

- Op welke wijze kunnen we overzicht verkrijgen en behouden in de complexiteit van opgaven, ambities en (ruimtelijke) transities om samenhang in visie en uitvoering te bewerkstellingen?

- Welke methodiek en instrumentarium kunnen we vormgeven en aanpassen om dit tot samenhang en versnelling te komen?

- Waar schittert het en waar schuurt het?

- Welke rol speelt het natuurlijk systeem daarin?

\section{Initiële aanpak en de complexe werkelijkheid}

Eind 2020 is door Wageningen Environmental Research een onderzoeksvoorstel geformuleerd om de vier centrale vragen te kunnen beantwoorden. Dit onderzoeksvoorstel ging uit van een drietrapsmodel. Enerzijds werd beoogd om scherp de gezamenlijke basis te kenschetsen van de regio zelf en in haar context, bestaande uit het natuurlijk basissysteem en het sociaal-economische basissysteem, anderzijds werd verondersteld inzicht te verkrijgen in de bestaande beleidsdocumenten en (ruimtelijke) plannen om de majeure opgaven en ontwikkelingsrichtingen goed in beeld te krijgen 
en scherp te krijgen waar potentiële synergie of mogelijke frictie te voorzien is. Tenslotte is daarbij ook cruciaal om het huidige speelveld te beschouwen.

Kortom, in deze preverkenning wordt ingezet op:

- Het op hoofdlijnen begrijpen van de systemen in het gebied (natuurlijk systeem en sociaaleconomisch systeem) in haar context en de wijze waarop deze nu meegenomen worden in de verschillende opgaven en dossiers

- Het scherp in beeld hebben van de opgaven, de reeds lopende beleidslijnen en initiatieven en de wijze waarop deze al ruimtelijke vertaald worden

- Het goed zicht krijgen op het speelveld, de organisatiekracht en het proces

Om inzicht te krijgen in de complexiteit van opgaven, ambities en (ruimtelijke) transities is gestart met het opzetten van een Atlas als methodiek. Immers een Atlas vraagt om een sterke structuur, duidelijke verhaallijnen, ruimtelijke beelden en kan zorgdragen voor een logisch, navolgbaar overzicht.

Verhaallijnen of in het Engels 'narratives', komen voort uit het samengaan van 'weten' en 'vertellen'. Een verhaallijn wordt geconstrueerd met een duidelijke structuur waarin alle aspecten en causale verbanden op een logische, navolgbare wijze worden samengebracht. Als verhalen met een duidelijk doel worden opgebouwd, kunnen ze als strategische verhaallijnen worden aangemerkt. Een verhaal kan meerdere verhaallijnen bevatten.

In de inventarisatiefase bleek dat de complexiteit van het huidige speelveld en de veelvoud aan beleidslijnen en plannen, de inhoudelijke lijn bijgesteld moest worden. Een volledig overzicht van alle beleidstrajecten en (ruimtelijke) plannen in Atlasvorm bleek een project aan zich te worden en daarmee het niveau van preverkenning te overstijgen. Kortom er ligt teveel om in kaart te brengen. $\mathrm{Er}$ zijn waardevolle nieuwe inzichten opgedaan tijdens deze inventarisatie en analyse, die zeker een beeld geven voor de methoden en aanpak naar integrale gebiedsplanning. Duidelijk werd dat een gedeelde basis ook nog geen vanzelfsprekendheid is. In overleg met de opdrachtgever is besloten om het onderzoek voor deze preverkenning vooral te focussen op de belangrijkste lessen zowel procesmatig als inhoudelijk. De focus is daarmee vooral komen te liggen op de eerste twee vragen, waarbij het hoe voorop komt te staan. Hoe kunnen we overzicht behouden en verkrijgen? En hoe komen we tot betere samenhang en daarmee versnelling? Daarmee samenhangend is uiteraard bezien op welke wijze (een gezamenlijk begrip van) het natuurlijk systeem daarin een rol kan spelen. De vraag waar het nu schittert of schuurt, oftewel hoe dossiers elkaar raken, kan hiermee nog niet beantwoord worden.

In dit werkdocument nemen wij u mee in ons gezamenlijk zoekproces, de complexiteit en de uiteindelijke uitkomsten, inzichten en adviezen. Wij hebben er bewust voor gekozen om dit rapport niet als eindrapport of wetenschappelijk rapport aan te merken, maar als werkdocument. Immers, het geeft de eerste conclusies van een gezamenlijke zoektocht en is de opmaat naar verdere uitwerking en verdieping met de NPLG werkgroep. 


\section{Veelvoud, verscheidenheid en verrassend verschillend}

Uiteraard springen we op een rijdende trein; de wereld staat niet stil. De regio 8RHK en ook de omringende regio's hebben op tal van dossiers de afgelopen jaren een breed palet aan ambities opgetekend in een veelvoud aan visies, (beleids)voornemens en plannen. Opgeteld meer dan 100, alleen al op (boven)regionaal niveau (zie bijlage 1). Daarnaast tekent zich ook een rijk speelveld af, waarop diverse structurele thematische en projectgebonden samenwerkingsverbanden actief zijn.

Ook bij de gezamenlijke droogteaanpak Achterhoek "Doen, delen, doordénken en doorpakken' is een dergelijke inventarisatie gedaan, waarbij meer dan 50 plannen relevant bleken.

In de beginfase van de pre-verkenning is getracht een zo goed mogelijk beeld te krijgen van alle relevant beleidsplannen, ambities en plannen op zowel bovenregionaal en regionaal niveau. Doel was enerzijds inhoudelijk in beeld krijgen welke (majeure) opgaven opgetekend zijn, welke dwarsverbanden getrokken worden of synergiën benoemd zijn en welke ruimtelijke strategie of maatregelen daarvoor ingezet wordt. Oftewel, zijn deze plannen en ambities ruimtelijk vertaald en in welke mate spelen de natuurlijke en sociaal-economische systemen en deelgebieden daarin een heldere rol? Daarnaast is ook beschouwd op welke wijze de doorwerking en afstemming van de diverse plannen op elkaar is.

De inventarisatie leverde al snel een groslijst op aan zowel analyses, beleidsplannen en ambities (zie bijlage 1). Tegelijk gaven deze beleidsplannen ook direct beeld op de diverse speelvelden die zijn gecreëerd en plangrenzen die worden gehanteerd. Duidelijk is dat er volop gewerkt wordt aan het landelijk gebied vanuit tal van invalshoeken en op verschillende speelvelden. Ook data is ruim beschikbaar in zowel rapportvorm als in diverse (geo)portalen. Zelfs voor de meest doorgewinterde onderzoeker is hier door de bomen het bos niet meer te zien. Het is vrijwel schier onmogelijk om in deze veelvoud snel en duidelijk overzicht te krijgen en inhoudelijke afstemming, inzichten en doorwerking goed te overzien. Dit hangt niet alleen samen met de veelvoud der dingen, maar ook met de wijze waarop gerapporteerd en geprojecteerd wordt. Dit maakt het dan ook extreem lastig om snel en tijdig synergiën of conflicterende aspecten te signaleren. Op hoofdlijnen is uit deze inventarisatie en analyse zowel inhoudelijk als procesmatig goed een lijn te destilleren. Tijdens de analysefase zijn de plannen beoordeeld systematisch op een aantal aspecten, zoals de duiding van opgaven, gehanteerde gebiedsindeling, de mate van ruimtelijke vertaling en projectie.

Om te weten waar het schitterend en schuurt is het juist cruciaal om van overzicht naar inzicht te komen. Daarin is het dan ook belangrijk dat de data en informatie bij elkaar gebracht kan worden. Waarom is dit niet (eenvoudig) mogelijk en wat valt op? 
Samengevat mogen de volgende conclusies getrokken worden:

- Er zijn teveel plannen om nog tot overzicht en inzicht te komen

- De plannen tonen een te grote diversiteit in zowel benadering (thematisch), begrenzing (schaal), (gebieds)indelingen en (kaart)uitwerkingen en ruimtelijke projecties

- Data is volop voorhanden, maar resulteert niet vanzelfsprekend tot overzicht en inzicht. De data leidt niet standaard tot informatie. En is in veel gevallen niet gekoppeld aan heldere verhaallijnen. Daarmee is dit niet direct bruikbaar op bestuursniveau of voor participatieve gebiedsprocessen.

De belangrijkste inzichten die gedestilleerd kunnen worden uit de analyse van zowel de plannen als de pogingen om tot overzicht en inzicht te komen zijn:

- Een gemeenschappelijke basis of vertrekpunt ontbreekt

- De doorwerking en verbanden tussen plannen en processen zijn minimaal.

- $\quad E r$ is sprake van een stapeling van plannen en disbalans tussen de thema's

- Data leidt niet vanzelfsprekend tot informatie en verhaallijnen

- De semantiek en definities lopen sterk uiteen.

In dit hoofdstuk zullen we op bovenstaande conclusies en inzichten nader ingaan. 


\subsection{Veel en verscheiden}

- Er zijn teveel plannen om nog tot overzicht en inzicht te komen

- De plannen tonen een te grote diversiteit in zowel benadering (thematisch), begrenzing (schaal), (gebieds)indelingen en (kaart)uitwerkingen en ruimtelijke projecties

De preverkenning heeft de titel Grenzeloze 8RHK gekregen, omdat niet alleen de verbanden binnen de thematiek worden gezocht, maar ook op de diverse schaalniveaus. Door de rijke thematiek in het landelijk gebied, alsmede de diverse schaalniveaus tekent zich al snel een veelheid en verscheidenheid af. Daarbij dient opgemerkt te worden dat de schaalniveaus zich niet alleen beperken tot de formele bestuurlijke schaalniveaus, maar dat er ook diverse samenwerkingsniveaus plannen hebben gemaakt op 'tussenniveaus', zoals de Agenda Oost (twee provincies) en de 8RHK-plus. Alles tezamen geeft dit al een grenzeloos perspectief.

Bovenregionaal zijn een aantal beleidstrajecten uitermate relevant. Recent is de Nationale Omgevingsvisie uitgebracht, de Omgevingsvisie Gelderland en de bijbehorende verordening is uiteraard uitermate relevant en ook de Omgevingsagenda Oost -een samenwerking van Rijk en de provincies Gelderland en Overijssel, waarin voor het landsdeel oost de belangrijkste opgaven en ambities zijn samengebracht, plaatst de regio in perspectief., maar ook op een hoger schaalniveau tekenen bewegende grenzen zich af. Daarnaast zijn landelijk en bovenregionaal ook diverse ambitiedocumenten en sectorale programma's uitgebracht -waaronder het Regionaal Waterprogramma, die handvatten bieden, maar niet altijd een concrete ruimtelijke uitwerking. Zowel de NOVI als de Omgevingsvisie Gaaf Gelderland (2018) benadrukken het belang van een integrale aanpak: " duurzaam, verbonden en economisch krachtig staan niet los van elkaar, maar versterken elkaar wanneer we taken en 'slim' combineren en 'gericht' inzetten". Desalniettemin wordt daarbij het 'hoe' verder niet specifiek gemaakt. Enerzijds worden de grote opgaven en ambities sectoraal behandeld en ruimtelijk op hoofdlijnen en met duidelijk verschillende resolutie en focus opgetekend, anderzijds wordt het belang van 'in samenhang met andere opgaven bezien en oppakken' constant onderstreept maar beperkt of niet uitgewerkt.

Al op bovenregionaal niveau valt sterk op dat de opgaven en ambities vaak anders geclusterd worden. Dit maakt het ons inziens het niet eenvoudig om de doorwerking op het geheel, maar ook op deelthema's goed te borgen. Alleen al de drie grotere bovenregionale beleidstrajecten tonen de verschillende benaderingen, de variatie in taal en terminologie en de mate van verdieping en verdeling tussen de thema's. Uiteraard zijn 'door de oogharen heen' de parallellen en verbanden te zien, maar voor de gemiddelde Nederlander ontstaat wel een breed en soms verwarrend palet. Overwegend tekent zich veelal een sectorale insteek, met beperkt systemisch inzicht in afhankelijkheden of doorwerkingen naar andere sectoren Een duidelijk, verbindend verhaal dat resoneert ontbreekt, althans het verhaal wordt telkens anders verteld met andere nuances, uitwerkingen, prioriteiten en accenten.

Dalen we verder af naar het regionale niveau dan valt op dat de regio Achterhoek net als de vele andere regio's in Nederland- een dynamisch speelveld kent, waarbij naast de vastomlijnde speelvelden aan de hand van bestuurlijke grenzen ook langs diverse thema's en ontwikkelingen separate speelvelden zijn ingericht. De grenzen van deze speelvelden verschuiven telkens, evenals de spelers op het veld. In principe kan dit voordelen opleveren, anderzijds is het essentieel dat continuïteit en doorwerking gewaarborgd blijven.

Het samenwerkingsverband 8RHK heeft een visie opgesteld: 'Achterhoek Visie 2030, Ruimte voor Innovatie, Groeien in Kwaliteit'. Hierin wordt de ambitie gesteld om 'te groeien, maar dat in kwaliteit'. Daarbij wordt aangegeven dat Smart living -de kwaliteit van wonen en leven- en Smart economy -het versterken van de economische kracht- de leidende principes zijn. Daarbij wordt de regio ook goed in de (boven)regionale context gepositioneerd. De leidende principes worden vervolgens uitgewerkt in 'streefbeelden', respectievelijk de productieve regio, de gekwalificeerde regio, de bereikbare regio, de schone regio, de leefbare regio en de gezonde regio. Wat vervolgens opvalt is dat daarlangs weer zes (bestuurlijke) thematafels zijn opgericht: Smart Werken \& Innovatie, Onderwijs \& Arbeidsmarkt, 
Wonen \& Vastgoed, Mobiliteit \& Bereikbaarheid, Circulaire Economie \& Energietransitie en de Gezondste Regio. De ruimtelijke uitwerking lijkt echter te ontbreken en het is interessant om te bezien hoe de opdeling weer samenkomt in een congruente ruimtelijk aanpak.

Ter illustratie is een gedeeltelijke projectie gemaakt van enkele van de grotere speelvelden. De speelvelden zijn geprojecteerd op de basiskaart met het natuurlijk systeem. Daarop zijn gemeentelijke grenzen, het beheergebied en de deelstroomgebieden van Waterschap Rijn en IJssel (WRIJ) geprojecteerd. Tenslotte zijn daarop de grenzen van de diverse samenwerkingsverbanden geplaatst. Centraal ligt uiteraard het samenwerkingsverband 8RHK, bestaande uit de 7 deelnemende gemeenten. Daarop voortbouwend wordt in diverse trajecten ook regelmatig de 8RHK + gehanteerd, waarbij de gemeenten in de Liemers, Lochem en Zutphen ook deelnemen. Dit maakt, evenals de stroomgebieden van WRIJ én het natuurlijk systeem, de verbinding naar de aangrenzende regio's, zoals de Stedendriehoek Apeldoorn-Deventer-Zutphen, de Groene Metropoolregio Arnhem-Nijmegen, regio Twente en Netwerkstad Twente. Op zowel regionaal als lokaal niveau wordt tenslotte generiek of specifiek op thema's samengewerkt met de aangrenzende Duitse gemeenten en regio.

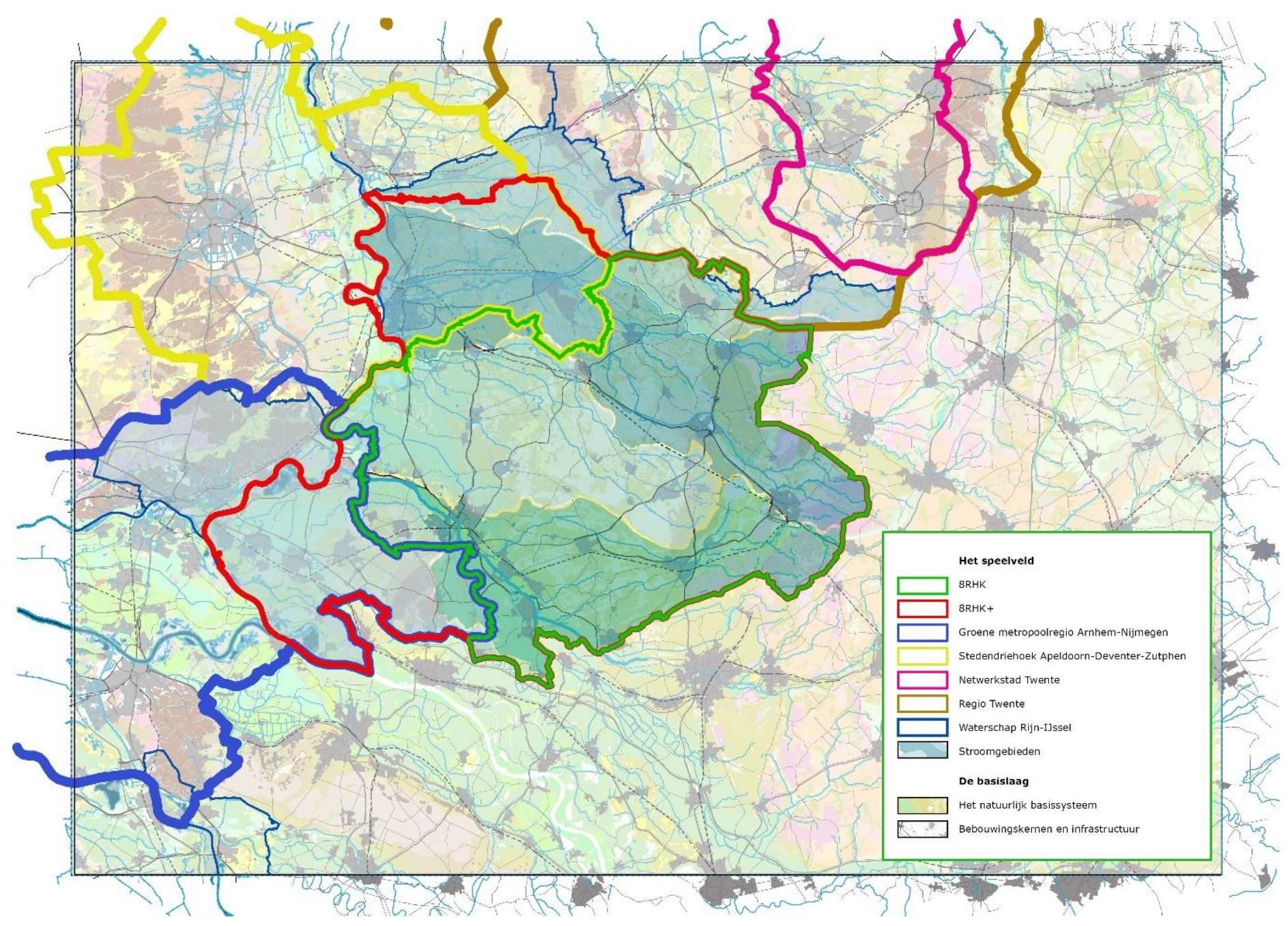

Figuur 1 Kaart Speelvelden in en om de Achterhoek

Op deze kaart zijn enkele speelvelden op (boven)regionaal niveau geprojecteerd. Deze begrenzingen van samenwerkingsverbanden laten overlap zien, maar ook verschillen. Wat vooral op valt is dat het natuurlijk systeem niet vaak de basis is om het speelveld te begrenzen. 


\section{Urgenties en opgaven}

De veelheid en de variatie valt in alle beleids- en ambitiedocumenten ook op de in het duiden van de urgenties en opgaven. In de meeste documenten wordt al snel ingezoomd op de diverse deelopgaven en ontstaat een soort van bloemlezing. Het is niet altijd even evident wat de verhaallijn is waarin alles samenkomt; zelfs bij de meer generieke beleidsdocumenten. De koppelingen naar andere dossiers worden in de meeste sectorale plannen maar marginaal benoemd en veelal niet uitgewerkt.

Desalniettemin doet de ordening der dingen er zeker toe en de plaats van de urgenties en opgaven binnen het systeem.

Er zijn een aantal majeure transities van belang, die uiteindelijk ook duidelijk relaties met elkaar zouden moeten hebben en bovenal in het zelfde gebied een plek moeten vinden en daarmee ook fysiek raken. Centraal daarin staan wel de draagkracht van het natuurlijk systeem en een bredere kijk op economie en welvaart.

De majeure transities zijn:

- klimaatmitigatie en -adaptatie

- voedseltransitie

- circulaire economie

- brede welzijn en inclusieve samenleving

Andere opgaven zijn meer specifieke uitkomsten of problemen die voortkomen uit de disbalans tussen het bestaande gebruik en de draagkracht van de natuurlijke en/of sociale systemen. Hierbij zijn veel opgaven (en oplossingen) 'losgezongen' van het natuurlijk systeem.

Het natuurlijk systeem staat onder druk en de systeemgrenzen lijken op veel plekken bereikt, maar daarmee staat ook het sociaal-economische systeem onder druk. Juist door deze in het perspectief te plaatsen van de majeure transities en de daaruit voortkomende opgaven, in samenhang, kunnen mogelijk meer duurzame oplossingen gevonden worden dan elk separaat (en tijdelijk) op te lossen. Goede voorbeelden daarvan zijn de stikstofdiscussie of de energietransitie. Zo hangt de stikstofproblematiek feitelijk samen met de fundamentele keuzen die wel of niet gemaakt worden in de voedsel- en landbouwtransitie en mobiliteit. Echter vooralsnog wordt vooral ingestoken op symptoom- en effectbestrijding. De energietransitie is een uitwerking van klimaatmitigatie, waarbij duidelijke verbanden getrokken kunnen worden naar de circulaire economie. Veelal zijn beide opgaven momenteel nog normatief van karakter, terwijl de weg voorwaarts vooral afhangt van de fundamentele keuzen en intrinsieke motivatie.

Wat opvalt in veel beleidsdocumenten, zowel bovenregionaal, regionaal als lokaal, is de keuze waarin deze majeure opgaven naast de andere opgaven worden ingedeeld. In veel gevallen worden deze in de inhoudsopgave op gelijke voet geschaard naast de sectorale behandeling van bijvoorbeeld landbouw, wonen, werken en bereikbaarheid, terwijl zij juist meer fundamenteel of conditionerend zijn. Te snel wordt in de directe problematiek of de deelstrategieën en oplossingen gedoken, terwijl de daadwerkelijk 'hamvragen' onbeantwoord blijven. Kortom de ordening der dingen doet er toe.

Enerzijds gaat het dan om de ordening tot een congruente verhaallijn waarbij het duidelijk plaatsen van transities en opgaven van majeur en overkoepelend tot effecten cruciaal is. De transities moeten de kern zijn, de opgaven de uitwerking. Daarin moet een duidelijke hiërarchie en verband zitten.

Daarmee zijn de diverse opgaven ook beter te duiden. Een oorzaak-gevolg analyse kan daarbij helpen. 


\subsection{Stapeling en balans}

- $\quad$ Er is sprake van een stapeling van plannen en disbalans tussen de thema's

Zoals al snel naar voren kwam is er een enorme stapeling van plannen, analyses en ambities. Het is niet alleen een stapeling van plannen, maar wat bovendien opvalt is ook de disbalans tussen (en de mate van uitwerking) van thema's. Zo valt op dat in de bovenregionale generieke plannen er een sterke focus is op de stedelijke en verbonden stedelijke regio's, het economisch vestigingsklimaat en groeipotentieel, terwijl de landelijke opgaven minder uit de verf komen. Anderzijds zie je een uiterst specifieke uitwerking op bepaalde thema's, zoals natuur en water. In tal van analyses en ambities worden die tot op zeer gedetailleerd niveau uitgewerkt en hebben een duidelijke doorwerking naar andere plannen. Hoewel de transitie van het landelijk gebied en de toekomstopgaven voor de landbouw wel worden benoemd, worden zij slechts beperkt of direct heel probleemgericht uitgewerkt. Voor de landbouw zijn relatief verspreide en verschillende ambities en een meer restrictieve beleidsuitwerking kenmerkend. Tekenend daarin is dat de diversiteit in het landelijk gebied en plaatsspecifieke eigenschappen zelden tot uitdrukking daarin komt.

\subsection{Doorwerking en verbanden}

- De doorwerking en verbanden tussen plannen en processen zijn minimaal.

Wellicht de crux van de analyse, de doorwerking van de verschillende beleidsplannen en ambities lijkt beperkt te zijn. Dit hangt naar verwachting ook samen met de wijze waarop wij nu de processen en planvorming hebben georganiseerd is en hoe dit tot uitdrukking komt. Desalniettemin door het ontbreken van deze doorwerking en verbanden wordt juist de inhoudelijk vraag waar het schittert of schuurt ook niet beantwoord, terwijl dit wel van wezenlijk belang is. 


\subsection{Begrenzing en gemeenschappelijke basis}

- De plannen tonen een te grote diversiteit in zowel benadering (thematisch), begrenzing (schaal), (gebieds)indelingen en (kaart)uitwerkingen en ruimtelijke projecties

- Een gemeenschappelijke basis of vertrekpunt ontbreekt

Naast de thematisch andere indelingen die naar voren komt uit de beleids- en plananalyse is het tekenend dat de plangrenzen en gebiedsindelingen ook sterk variëren, zonder dat daarbij een gemeenschappelijke basis wordt gehanteerd. Elk plan maakt haast telkens weer een eigen analyse van een gebied, soms meer of minder systemisch van aard, en komt tot eigen deelgebieden. Een heldere gemeenschappelijke basis en begrip van de relevante systemen en de relaties daartussen ontbreekt.

\section{Ruimtelijke vertaling en projectie}

Hoewel het begrip gebaat is bij consistente ruimtelijke vertalingen en projecties, zowel van de huidige situatie als de beoogde situatie, is ook hier sprake van een rijke variatie. Niet alle plannen kennen een ruimtelijke vertaling of projectie; en als deze wel gemaakt is openbaart zich wederom een rijke variatie daarin. De mate van uitwerking, detail en type projectie is zeer uiteenlopend; niet alleen tussen de plannen maar ook binnen de plannen op onderwerpen.
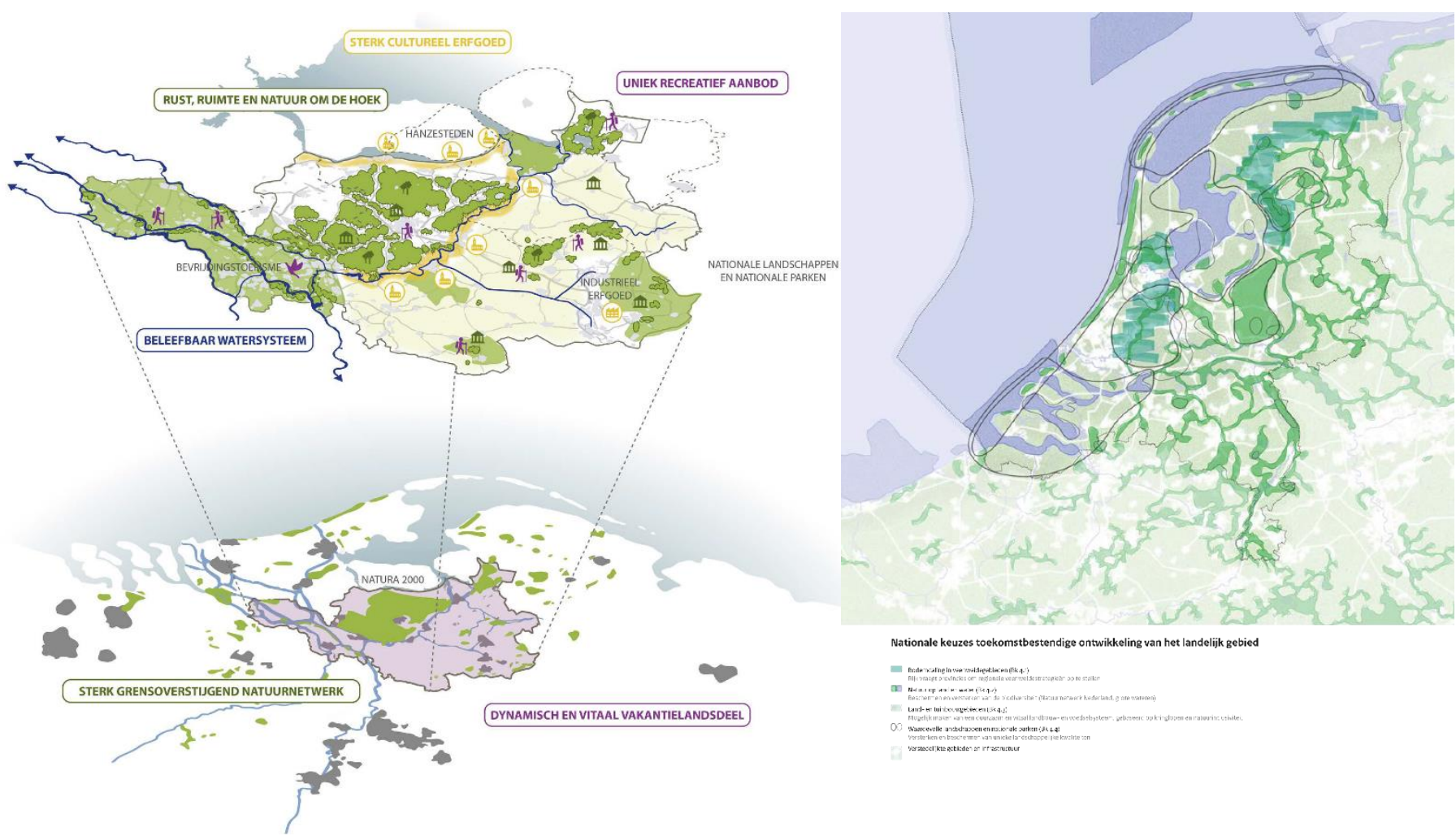

Figuur 2 Verschillende projecties maken het vergelijken en begrijpen niet makkelijker (voorbeeld projectie Agenda Oost (links) en NOVI (rechts)) 


\subsection{Data en informatie}

- Data is volop voorhanden, maar resulteert niet vanzelfsprekend tot overzicht en inzicht. De data leidt niet standaard tot informatie. En is in veel gevallen niet gekoppeld aan heldere verhaallijnen.

De afgelopen jaren is er volop data verzameld op de diverse thematiek. Deze data is op een keur van portals toegankelijk gemaakt, zoals de recente Atlas van de Leefomgeving (PBL), het geoportaal van de provincie Gelderland en de 8RHK monitor (zie bijlage 2). De duiding en plaatsing van deze

informatie is zeer uiteenlopend. De 8RHK monitor illustreert de data al duidelijk in verhaallijnen, maar de overige portalen laten het verhaal en de interpretatie daarvan nog veelal aan de gebruiker. Ook in deze data is vaak een verschil waarneembaar in detail en plek in de problematiek. Zo is bijvoorbeeld prima data te vinden over de stikstofdepositie, maar dit laat niet het verhaal zien; immers waar komt deze depositie vandaan en over welk type stikstof hebben we het dan? Wederom gaat het hier dus om een oorzaak-gevolgrelatie die er toe doet. Om daadwerkelijk van deze data informatie te maken en de ze goed in de discussie te plaatsen is dan nog het nodige werk nodig. 


\subsection{Definities en taal}

- De semantiek en definities lopen sterk uiteen.

Wellicht het meest opmerkelijke is de taal en terminologie die gehanteerd wordt. Hoewel overeenkomsten en verbanden te leggen zijn is er een rijke variatie aan termen die gebruikt wordt. Het is daarbij ook niet altijd duidelijk wat dat specifiek inhoud en wat de definitie daarachter is. De vraag is dan ook of dat voor ieder dan ook gelijk is of dat er verschillende interpretaties mogelijk zijn. Een goed voorbeeld daarvan is circulariteit of circulaire economie.

Toekomstbestendige ontwikkeling van het landelijk gebied

\section{NATUURINCLUSIEF}

\section{VERANKERDE GRENSOVERSTIJGENDE GOEDERENCORRIDORS}

Transitie landelijk gebied

Gezond, veilig, schoon en welvarend

\section{Schone regio}

Balans landgebruik en kwaliteit landschap, bodem, water en lucht

\section{Productieve regio}

VERBONDEN EN DUURZAME

STEDELIJKE REGIO'S

BELEEFBAAR EN DUURZAAM

WATERSYSTEEM

Duurzaam economisch groeipotentieel

Bereikbare regio

Biodiversiteit beschermd en versterkt en natuurlijk kapitaal duurzaam benut

KRINGLOOPLANDBOUW 


\subsection{Reflectie}

Recent zijn er diverse landelijk adviezen uitgebracht, die juist ook een aantal van bovenliggende noties in perspectief plaatsen en benadrukken. Los van de uitgebreide discussies over met name de grote woningbouwopgave en daaraan gekoppelde strategie, zijn de rapportages 'Grote opgaven in beperkte ruimte' (PBL, 2021), 'Kiezen en Delen' (ABDTOPConsult, 2021) en 'De Bodem bereikt' (RLI, 2020) in dit kader uitermate relevant.

In het advies 'De Bodem Bereikt' constateert de Raad voor de Leefomgeving dat het niet goed gaat met de rurale bodems in Nederland en dat vitale bodems cruciaal zijn voor een duurzaam economisch perspectief. De raad stelt het uitgangspunt dat de vitaliteit van de bodem leidend is voor de functies die erop kunnen plaatsvinden. Functies volgen bodem. Gekoppeld daaraan adviseert de raad meervoudig gebruik te stimuleren. De daadwerkelijk uitwerking daarvan en wat dat betekent in ruimtelijke zin en voor de diverse ontwikkelingen ligt volgens de raad primair bij de provincies, terwijl het rijk deze principes of uitgangspunten zal moeten borgen in de Nationale omgevingsvisie. Gesteld mag worden dat de RLI dus opteert om het bodem (en watersysteem) leidend te laten zijn in de verdere ontwikkelingen.

Dat laatste resoneert ook in het advies 'Kiezen en delen' van de Studiegroep Ruimtelijke Inrichting Landelijk gebied. Na een uitvoerige analyse op hoofdlijnen op de opgaven die centraal staan, stelt de studiegroep drie inrichtingsprincipes als leidraad voor:

- $\quad$ bodem- en watersysteem leidend voor keuzes landgebruik

- functies en bestemming die elkaar in de weg zitten en/of minder goed bij elkaar passen uit elkaar halen

- functies clusteren om identiteit van gebied te beschermen of te versterken of om voldoende schaal te creëren

Zij stellen voor per gebied de draagkracht van het bodem- en watersysteem en het landschap bepalen en ook zij merken op dat de provincies als regisseur worden gezien van het omgevingsbeleid op regionale schaal en het organiseren van de benodigde samenwerking. Het Rijk zou dan een actieve rol moeten innemen om te borgen dat opgaven integraal en in logisch samenhangende deelgebieden moeten worden aangepakt.

Daarbij mag worden opgemerkt dat het bepalen van de draagkracht van het bodem- en watersysteem alleen kan als ook duidelijk is waar dat op gebaseerd wordt. Volstaat het bodem- en watersysteem als natuurlijke basis of moeten daar nog elementen aan toegevoegd worden? Welk referentiekader hanteer je voor de draagkracht? Is de draagkracht te vergroten of zijn de functies aan te passen? Welke logisch samenhangende deelgebieden komen daaruit naar voren en hoe borg je het gedeeld begrip daarvan en de constante verankering in alle analyses, plannen en ontwikkelingen? Cruciaal is dan ook om in gezamenlijkheid dit te ontdekken, vast te leggen en te omarmen!

Vervolgens is de vraag alvorens de principes van clusteren of scheiden te kunnen toepassen, wat maakt dat functies elkaar in de weg zitten of minder goed bij elkaar passen of wanneer voldoende schaal nodig is en welke deze dan is? In het licht van het RLI advies, maar ook van het kansen creëren en nieuwe perspectieven te openen, zien wij het belangrijkste principe vooral de synergie opzoeken of mogelijk te maken. Echter om dit te doen, zullen de ambities en projecties ook goed over elkaar gelegd moeten kunnen worden en de deelsystemen en werking daarvan, alsmede ook de motieven en intrinsieke waarden, ook door een ieder moeten worden begrepen. Gedeeld begrip en een gezamenlijk taal zullen wederom daarvoor van belang zijn.

In de publicatie 'Grote opgave in een beperkte ruimte' maakt ook PBL de notitie dat de balans tussen de gebruikswaarde, belevingswaarde en toekomstwaarde in het huidige landgebruik en ruimtelijk ontwikkeling niet op orde is. Ook PBL stelt sterkt dat de eenzijdige oriëntatie op het maximaliseren van de gebruikswaarde de kwaliteit van de leefomgeving onder druk zet. De grenzen van de draagkracht van het onderliggende fysieke systeem, zo stellen zij, zijn in zicht of al overschreden. En juist dat heeft consequenties voor de toekomstbestendigheid. Niet alleen van datzelfde onderliggende fysieke systeem, maar juist ook de gebruikswaarde en de belevingswaarde. Ook zij roepen dan ook op 
om het bodem- en watersysteem veel meer dan voorheen centraal te stellen als structurerend principe in het omgevingsbeleid.

Daarbij wordt opgemerkt dat het Rijk op twee manieren naast de sturing op proces meer inhoudelijk verantwoordelijkheid, door sterker te sturen op urgente sectorale thema's en in de vorm van een nationaal integraal omgevingsbeleid waarin zelf ook belangrijke ruimtelijke afwegingen worden gemaakt.

De meest recent adviezen rondom de stikstofcrisis, onderstrepen het eerdere belang van de strategische keuzes en een gebiedsgerichte aanpak in een breder perspectief (PBL 2021, Erisman, 2021). Waarbij echter het ene advies uitgaat van een terechte signalering en agendering, gaat het andere advies al in directe oplossingen. Deze gebiedsgerichte aanpak en behorende strategieën en oplossingsrichtingen, inclusief de majeure keuzes op de transities, zullen echter altijd onderdeel moeten uitmaken van een gezamenlijk proces. Vaak wordt de vraag gesteld: "Is er in de toekomst nog ruimte voor dé landbouw?". Deze vraag is echter niet simpel te beantwoorden, zonder te weten welk referentie voor dé landbouw gehanteerd wordt (immers dé landbouw bestaat niet, maar is een samenstel van vele vormen) en wat de bredere doelstelling is, waarmee dit wel of niet samen kan gaan.

Echter proces en inhoud raken elkaar telkens, zoals onze analyse al uitwijst. De wijze waarop we zaken hebben georganiseerd en de inhoudelijke lijn, doorwerking en inzichten borgen zijn cruciaal. PBL stelt ook dat het omgevingsbeleid niet alleen op fysieke grenzen stuit, maar ook op de sociale. $\mathrm{Zij}$ pleiten voor extra aandacht voor het betrekken van de samenleving het creëren van maatschappelijk draagvlak door zowel betrokkenheid als vertrouwen te vergroten. Daarbij merken ze op dat duidelijke lange termijn doelen, helder kaders en een goed begrip van de leefwereld van burgers noodzakelijk zijn. Hieraan zouden wij willen toevoegen dat ook de burgers, de maatschappij en de professionals een gedeeld begrip van die leefwereld zouden moeten delen: een gemeenschappelijk en gedeeld vertrekpunt alsook verhaal van de toekomst.

Op basis van het voorgaande, is dan ook de centrale vraag wat noodzakelijk is om te komen tot een inspirerende, motiverende en integrale aanpak. De inzichten uit de analyse komen samen tot de sleutels naar integraal werken. Daarin zitten zowel procesmatige als inhoudelijke ingrediënten, waarbij het natuurlijk systeem centraal staat!

In het volgende hoofdstuk wordt op een aanpak voorgesteld om op basis van een gemeenschappelijk begrip het natuurlijk systeem weer als ordenend principe en verbindende factor in te zetten. 


\section{De sleutels naar 'integraal'}

De roep om regie en de vraag naar integraal is de laatste twee jaar sterk toegenomen. Bij beide termen is onduidelijk wat precies bedoeld wordt en wat de noodzaak of meerwaarde precies is. In dit hoofdstuk wordt op basis van de kritische analyse van de huidige praktijk en worsteling om te komen tot een samenhangende en integrale aanpak een voorstel gedaan voor mogelijke bouwstenen en methodes die in gezamenlijkheid kunnen leiden tot een meer congruente aanpak, verbetering en versnelling. Een verbetering en versnelling die ook duidelijk de samenhang en synergie opzoekt. Die samenhang en synergie komt samen in het systeem of de systemen.

De juiste interventie op de juiste plek, kiezen maar vooral delen, op basis van gedeeld (systemisch) begrip en gedeelde ambities. Verschuiving van sectorale problemen naar integrale perspectieven en duurzame systemische oplossingen... het probleem achter het probleem aanpakken.

Duiken we in de wereld van de integrale planvorming en de praktische aanpak en methodieken daartoe, valt op dat een eensluidend begrip van integrale planvorming nog geen gemeengoed is, laat staan dat duidelijk is wat de beste processen en methoden zijn die daarvoor ingezet kunnen worden.

Zoals Van Straalen in 2012 al concludeert: "Hoewel integratie een sleutelconcept in de ruimtelijke planvorming is, is de feitelijke betekenis daarvan in relatie tot de verschillende planningsprocessen en verschillende perspectieven van stakeholders nog steeds vaag (Van Straalen, 2021).

Tisma en Meijer merken in hun analyse van de leerpunten vanuit ruimtelijke planvorming in Nederland op dat de zoektocht naar synergie tussen ruimtelijke functies noopt tot een aanpak waarin samenwerking centraal staan (Tisma, 2018). Daarbij geven zij aan dat vanuit het erkennen en herkennen van elkaars belangen en de intrinsieke motivatie om samen te werken daarbij, nieuwe oplossingen kunnen ontstaan. Daarbij wordt de aantekening gemaakt dat een integrale aanpak mogelijk meer kosten met zich meebrengt, maar ook veel oplevert -onder andere sociaalmaatschappelijke voordelen. Deze aantekening is vooralsnog twijfelachtig. Indien goed ingericht en gekoppeld aan een slim proces kan onder aan de streep een integraal proces wellicht juist aanzienlijk voordeliger zijn en uiteindelijk meer resultaat leveren.

Diverse studies benadrukken de continue verschuiving in paradigma's in ruimtelijke planvorming in beleid en praktijk in Nederland, waarbij opgemerkt mag worden dat de laatste decennia vooral een trend waarneembaar is naar decentralisatie van verantwoordelijkheden op het gebied van ruimtelijke planvorming en een sterke focus op sectorale planning en een incrementele aanpak (Tisma, 2018; Claassens, 2020; Balz, 2018; Straalen, 2016). Zet je dit echter af tegen de diverse inzichten die de afgelopen decennia naar voren komen uit onderzoek op zowel planning, beleid en de transities zelf, tekent zich juist het tegenovergestelde af: de roep naar een holistische, integrale aanpak. Daarbij mag zeker geconcludeerd worden dat een sectorale aanpak onvoldoende potentiele synergiën naar voren brengt of wrijving signaleert, en dat een incrementele aanpak vaak direct ingaat op het oplossen van directe problemen in plaats van het oppakken van de hamvragen en strategische keuzen rondom de transitie(s) zelf. De incrementele aanpak wordt vaak gepropageerd als de beste aanpak aangezien veranderingen langzaam en stap voor stap worden doorgevoerd en de verwachting daarmee bestaat dat dit beter tot acceptatie en implementatie leidt (Roggema, Vermeend and Van den Dobbelsteen, 2012). De vraag of de praktijk van alledag dat nu uitwijst, gelet op de moeizame voortgang op tal van dossiers. Daarmee niet gezegd hebbende dat een incrementele aanpak per definitie niet werkt, maar wellicht is er een duidelijke samenbindende richting noodzakelijk die de uitwerking en terugkoppeling versterkt. 
Het natuurlijk systeem biedt een gemeenschappelijke 'taal' en gemeenschappelijke ruimte dat deze integratie kan faciliteren (Mang, 2012).

Het is van belang om scherpe, gedeelde doelen en principes te formuleren die van invloed zijn op meerdere sectoren en domeinen om meer integratieve en interdisciplinaire benaderingen te stimuleren (Mang, 2012). Kortom, een gedeeld begrip van het natuurlijk systeem, de gebiedskarakteristieken, gekoppeld aan een gedeeld positief perspectief waar meerdere -zij het niet alle- sectoren en domeinen samenkomen, zullen uiteindelijk de daadwerkelijke realisatie en versnelling daarvan versterken (Skilbeck, 2016). Dit wordt verder uitgewerkt en benadrukt in het 'wedding cake'-model van het Stockholm Resilience Institute -zoals ook opgenomen in de Nationale Omgevingsvisie. Het model toont duidelijk het belang van het natuurlijk systeem als basis voor een gezonde maatschappij en sterke, veerkrachtige economie en de interacties daartussen (Stockholm Resilience Institute, 2016). De grote vraag is uiteraard om dit meer concreet, herkenbaar en invoelbaar te maken. De uitwerking op lokaal en regionaal niveau is daarvoor cruciaal, alsmede de doorvertaling en borging in de overkoepelende en specifieke planprocessen.

De sleutels naar integraal, oftewel de bouwstenen naar een daadwerkelijke integrale aanpak, zowel in begrip als perspectief zijn in onze optiek:

- een samenbindende, gedragen visie op basis van gedeeld begrip van het natuurlijk systeem

- een participatieve oorzaak-gevolg analyse

- een gedegen strategie van integraal en sectoraal

Uiteraard zijn bouwstenen en voorbeelden van synergiën ook cruciaal -denk daarbij aan technieken en ontwerpen-, maar de praktijk laat zien dat er al legio voorbeelden zijn. Er is juist behoefte het goed plaatsen in het systeem en het opschalen. Om dat goed te doen bieden de eerste drie sleutels de kapstok, in combinatie met goede voorbeelden, de weg naar voren.

- $\quad$ ter ondersteuning zijn goede voorbeelden van belang

Deze sleutels naar integraal worden in de volgende paragrafen nader toegelicht.

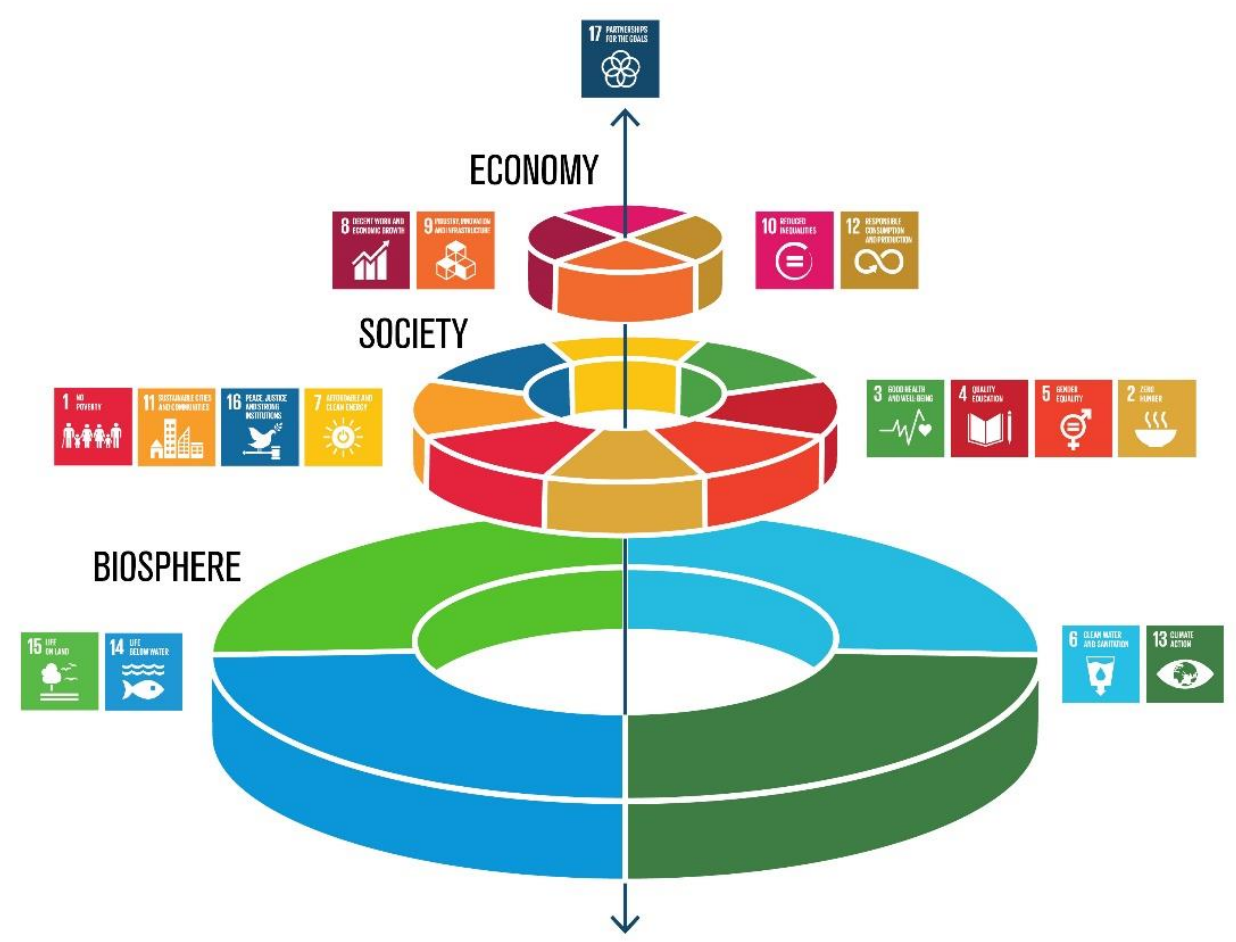

Figuur 3 Wedding cake model: het natuurlijk systeem aan de basis (Stockholm Resilience Institute, 2016) 


\subsection{Gedeelde en gedragen samenbindende visie op basis van gedeeld begrip natuurlijk systeem}

\section{Gedeeld begrip met natuurlijk systeem als basis}

Met de natuurlijke basis in beeld zijn er legio projecties mogelijk die laten zien hoe verrassend vaak die natuurlijke basis doorschemert in de verschillende aspecten van het gebied. Het versterkt dan ook de roep om deze basis ook als gemeenschappelijk vertrekpunt beter te borgen en te sterken. Zoals gezegd, was in eerste instantie ingezet om de methodiek van een Atlas dit verder vorm te geven. Enerzijds om dit in beeld te krijgen, anderzijds om de relaties goed te duiden. Hoewel niet volledig en slechts een aanzet, laten deze kaarten wel goed de meerwaarde van deze methodiek zien. Belangrijk daarin wel is de gezamenlijke verhaallijn(en) en opbouw om aansprekend en voor iedereen begrijpelijk dit neer te zetten. De conclusie uit het onderzoek is in ieder geval dat dit niet vanachter het bureau gedaan kan en mag worden, maar onderdeel is van een breed gedragen, interactief en participatief proces. Er mag ook geconcludeerd worden dat -hoewel sterk verspreid- er volop data beschikbaar is over legio onderwerpen, maar dat daar juist de schoen wringt. Welke data is op welk moment relevant en vertelt welk verhaal?

Naast het construeren van duidelijke verhaallijnen, de ruimtelijke projecties in een Atlas-vorm, zal de oorzaak-gevolganalyse (4.2) ook zeer waardevol zijn, met name om de verbindingen te ontdekken tussen de transities en opgaven en het bepalen van strategische of meer operationele doelen en maatregelen en de effectiviteit daarvan.

\section{Gedragen en samenbindende visie op basis natuurlijk systeem}

Het natuurlijk systeem en op de natuur en dit natuurlijk systeem gebaseerde oplossingen, 'nature based solutions', hebben de kracht en de urgentie om een prominente rol te spelen in het perspectief op de majeure transities waar we voor staan (EEA, 2021, Seddon, 2020). Juist dit natuurlijk systeem legt de verbindingen tussen sectoren, opgaven en gaat voorbij administratieve grenzen en legt een stevig betrouwbaar fundament voor de maatschappij en de economie (GCEC, 2016; Nesshöver, 2017). Het begrijpen van deze causale relatie is van groot belang. Dit begrip zal samen verkregen moeten worden om aan kracht te winnen en ook daadwerkelijk effect voor te sorteren. De vertaling daarvan in duidelijke strategische verhaallijnen die motiveren en activeren kan daar vervolgens behulpzaam bij zijn. Bij het construeren van strategische verhaallijnen wordt rekening gehouden met de verschillende invalshoeken, belangen en motieven, maar staat bovenal een positieve, aansprekende en activerende boodschap centraal. Feitelijk zullen deze strategische verhaallijnen een ieder ook persoonlijk moeten aanspreken en inleefbaar en flexibel zijn (Coninx, 2018; Coninx, 2020) en rekening houdend met de ontwikkelingen in de tijd. Juist de ruimtelijk vertaling maakt het ook specifiek en concreet en brengt het dichtbij.

Dit vergt een delicaat proces, maar indien zorgvuldig en met de juiste insteek en toon, kunnen lange termijn perspectieven een belangrijke rol spelen in een coherente aanpak, handelingsperspectieven en ontwikkelingsrichtingen (Van Rooij, 2021). Daarbij is het goed op te merken dat een dergelijk langetermijnperspectief niet statisch is (geen blauwdruk), maar een open gewenste richting aangeeft welke door de tijd heen aangepast en versterkt kan worden op basis van voortschrijdend inzicht (Hölscher, 2020). Al met al, zorgt het echter wel voor de verbinding. 


\section{Aanzet kenschets De Grenzeloze 8RHK}

Om de diverse ontwikkelingen in en om de Achterhoek uiteindelijk goed in perspectief te plaatsen kenschetsen we de regio aan de hand van het natuurlijk basissysteem en het sociaaleconomische systeem. Een goed begrip van dit fundament biedt namelijk ook een sterke basis voor het samenbrengen en in perspectief plaatsen van de majeure opgaven waar de regio en haar bredere context de komende decennia voor staat. De samenhang, maar ook de diversiteit biedt kansen om ontwikkelingen aan kracht te laten winnen.

Deze kenschets duidt de essentie van beide systemen en is bedoeld als inspiratie en gemeenschappelijke basis.

\section{Het natuurlijk basissysteem}

Als we naar de natuurlijk basis kijken is het uiterst relevant om even uit te zoomen en de internationale grenzen te beslechten. Het natuurlijk basissysteem definiëren we als het samenspel tussen de natuurlijke ondergrond, het watersysteem (grondwater en oppervlaktewater) en de natuurlijke structuren.

Voordat we inzoomen op de Achterhoek in al haar verscheidenheid is het goed eerst even het grotere plaatje te bekijken. Immers het natuurlijk basissysteem van de Achterhoek wordt gedefinieerd door haar unieke positie en de daarbij behorende variatie en overgangen.

De Delta van Maas, Rijn en Schelde wordt aan de zuidzijde begrensd door het Kempisch plateau en aan de oostzijde door het Oost Nederlands plateau, beiden met een gradiënt van dekzandgebieden naar het rivierengebied.

De Achterhoek ligt op de kenmerkende gradiënt van het Oost Nederlands plateau in het oosten naar het rivierengebied van de Oude IJssel, de IJssel en de Rijn. De regio omvat feitelijk de gehele gradiënt, maar belangrijk is om te realiseren dat grote delen van het basissysteem ook grensoverschrijdend zijn. Hoewel de grenzen van de regio 8RHK -zijnde de huidige 7 samenwerkende gemeenten- uitgelicht is, is nadrukkelijk het grenzeloze perspectief in beeld gebracht. Immers de systemen en structuren zijn grenzeloos, hetgeen de afhankelijkheden en synergie ook goed duidt.

Zo is het geohydrologische systeem sterk afhankelijk van de infiltratie op het Oost Nederlands plateau, waarvan een groot deel tot ver in Duitsland loopt, maar ook de Oude IJssel samen met de Bocholter Aa, de Slinge en de Berkel ontspringen in Duitsland en het grote delen van de stroomgebieden liggen in Duitsland. Uitzondering daarop is de Baakse Beek, die haar brongebied kent op Nederlands gebied. Zeker vermeldenswaardig is ook dat de Oude IJssel oorspronkelijk ook als overloop voor de Rijn functioneerde. Kortom, het is dan ook essentieel om de cruciale relatie met de brongebieden en bovenstroomse gebieden in Duitsland telkens in ogenschouw te nemen.

Veelal is er sprake van een complexe geohydrologie met een grote ruimtelijke variatie, zowel op regionaal als lokaal niveau. Van oost naar west kan een onderscheid worden gemaakt in het unieke, maar eveneens complexe en aardkundige waardevolle gebied rond Winterswijk, het van noord naar zuid uitstrekkende droogdal op de overgang van het plateau naar het dekzandgebied, en dekzandgebieden die een rijk en complex patroon laten zien van hogere dekzandruggen, dekzandvlakten en -van oorsprong- afvoerloze laagten en worden doorsneden door talrijke beekdalen. Een complexe geohydrologische basis welke door sterk veranderend landgebruik en waterbeheer aanzienlijk beïnvloedt is door de eeuwen heen.

Tussen het rivierengebied van de Oude IJssel en Rijn manifesteert het Montferland zich. Montferland is oorspronkelijk verbonden met de stuwwal van Nijmegen, maar door de doorsnijding van de rivieren is deze daarvan los komen te liggen. Het is goed te realiseren dat de regionale grondwaterstromen vanuit het Oost Nederlands plateau ook tot voorbij Montferland reiken. 


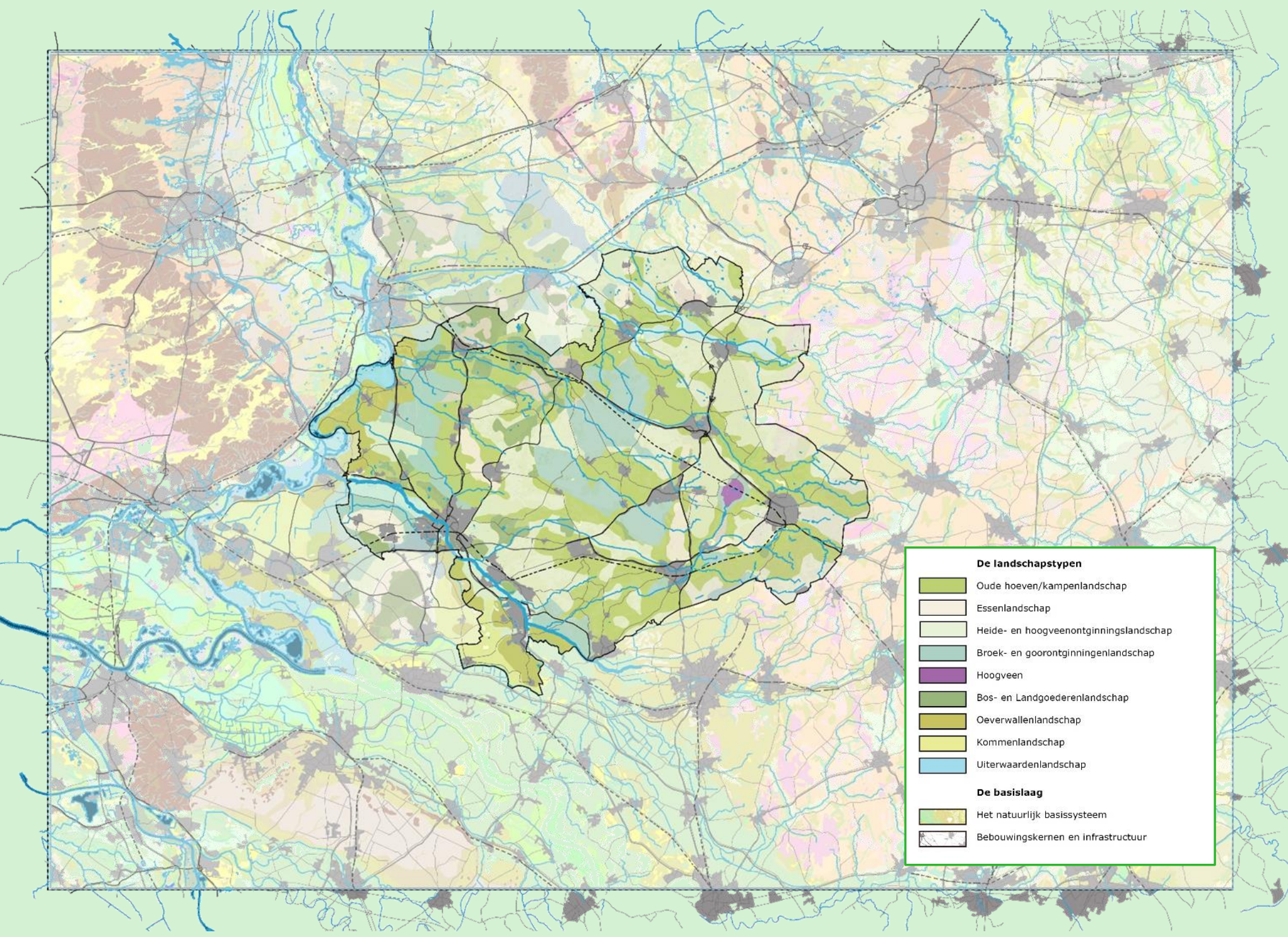

Figuur 5 Landschapstypen en het natuurlijk basissysteem (WUR, 2021):

de ligging van een landschapstype in het natuurlijk systeem doet er zeker toe en maakt verschil

De vraag is dan ook hoe (toekomst)waarden toe te voegen met respect voor bestaande waarden. Hiermee kunnen bestaande landschapskwaliteiten worden versterkt of nieuwe kwaliteiten worden toegevoegd. Belangrijk is wel dat de draagkracht van het natuurlijke systeem beter aan de basis moet komen te staan: het bestendigen of versterken van het natuurlijk systeem om ook op de lange termijn de kwaliteiten en kansen te behouden.

Draagkracht is een relatief begrip en sterk afhankelijk van de situatie. Draagkracht is het vermogen van de natuur om de gevolgen van menselijk ingrijpen op te vangen, zonder dat het natuurlijk evenwicht wordt verstoord. Waar liggen de grenzen van de draagkracht en aan welke knoppen gaan we draaien? Het is een samenspel tussen het natuurlijk systeem, de transities en de ambities. 
Onlangs is in het kader van de Aanpak droogte Achterhoek al een mooie aanzet gedaan in de typering en opzet van verbindende deelgebieden. Overigens is het goed daarbij op te merken dat in dit project de bredere begrenzing van $8 R H K+$ is gebruikt. Daarnaast is in de verbeelding alleen de informatie binnen de begrenzing gegeven, het zou in de communicatie en duiding sterker zijn om deze door te laten lopen, zodat zicht ontstaat en benadrukt wordt hoe een en andere in haar context ligt en relaties liggen met de aangrenzende gebieden. Desalniettemin is dit een goede basis om gezamenlijk op verder te bouwen.

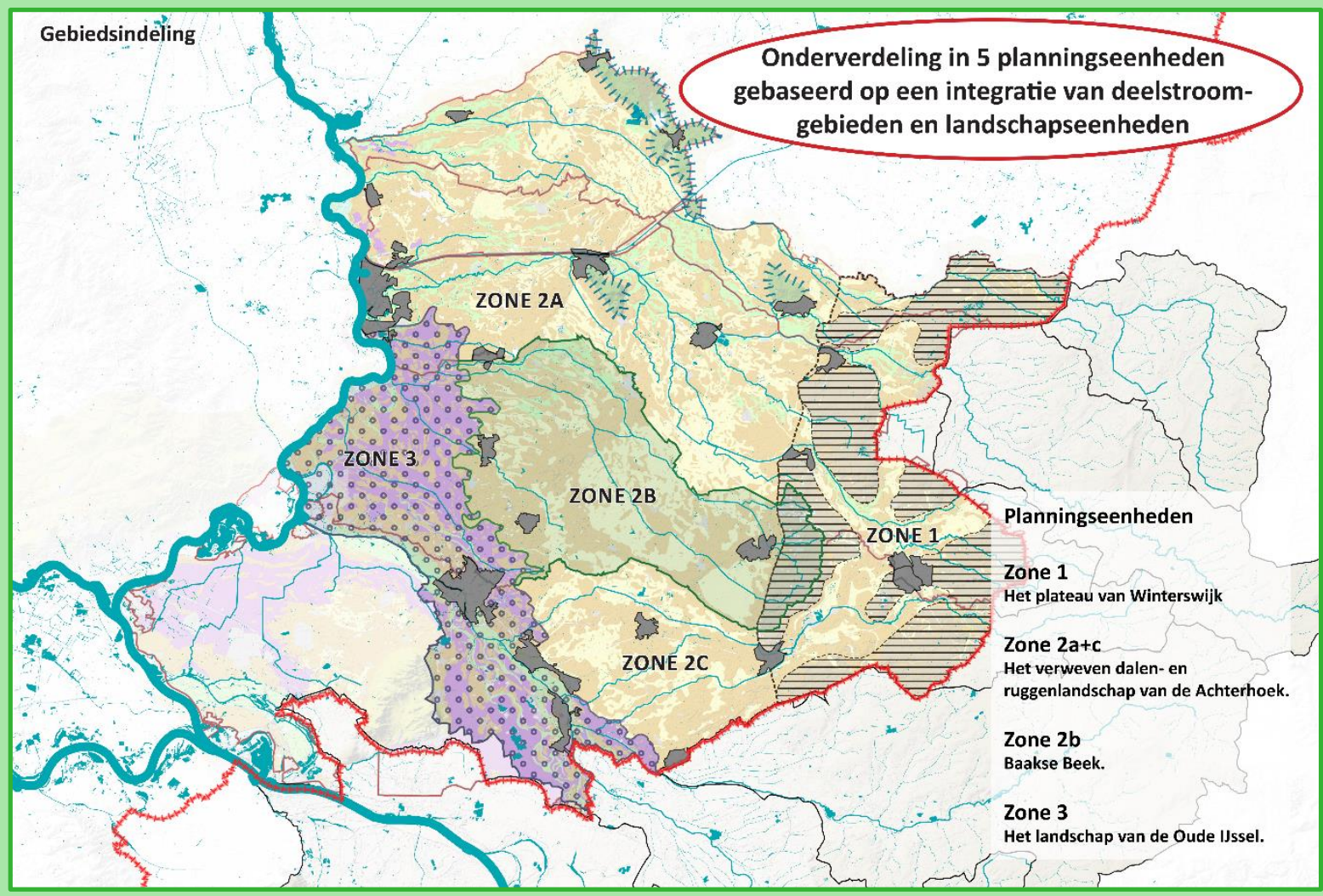

Figuur 6 Aanzet gebiedsindeling Aanpak Droogte Achterhoek $(H+N+S, 2021)$ 


\section{Het sociaal-economische basissysteem}

Het natuurlijk basissysteem heeft ook aan de basis gestaan van het huidige sociaal-economische systeem. Het natuurlijk systeem heeft ook cultureel en economisch in het gebied verschillende ontwikkelingen mogelijk gemaakt. Denk daarbij aan de industriële ontwikkeling langs de Oude IJssel versus de landbouweconomie op de dekzandvlakten en het plateau. Of de toeristisch-recreatieve ontwikkelingen. Ook de oriëntatie naar buiten de regio, denk daarbij aan de nabijheid van de groene metropoolregio Arnhem-Nijmegen, Zutphen-Apeldoorn, Twente en zeker ook Duitsland doen er toe.

De pragmatische volksaard, het 'Naoberschap' en het ondernemerschap is van grote waarde. De regio kent zowel innovatief midden-en kleinbedrijf, als een grote agrarische sector en een sterk belang van de toeristisch-recreatieve sector. Hierin spelen verschillende belangen, maar liggen ook potentiële relaties. De aangrenzende regio in Duitsland heeft een vergelijkbaar sociaal-economisch profiel, waarbij de oosterburen een sterke economische groei hebben gekend in de laatste jaren.

Andere belangrijke sociaal-maatschappelijke aspecten die meegenomen zullen moeten worden zijn grondposities, waaronder de talrijke landgoederen en buitenplaatsen, en de demografische ontwikkelingen. Denk daarbij onder meer aan de toenemende aantrekkingskracht van de regio voor huizenbezitters. De Achterhoek behoort begin 2021 tot de top 5 van regio's die het meest in trek zijn bij Randstedelingen (CBS, 2021). De demografische verschillen en verschuivingen binnen de regio zelf alsook de culturele en economische aspecten zullen goed meegenomen moeten worden in de gebiedsontwikkelingen. Overigens blijft de aanduiding in de dataset van de regio als 'nationale periferie" een negatieve connotatie, die zeker geen recht doet de regio.

De Achterhoek Monitor, die veel van deze gegevens bijhoudt, is voor deze inzichten zeer waardevol, mits de ruimtelijke projectie van deze gegevens ook gemaakt wordt. In principe zijn de gegevens per gemeente al uitgesplitst.

Zoals gezegd, mag geconcludeerd worden dat een Atlas nog steeds een waardevolle methodiek en instrument is om het verhaal inzichtelijk te maken en te delen. Nemen we het natuurlijk systeem zoals voorlopig gedefinieerd en projecteren we daarop een divers aantal aspecten dan valt de ruimtelijke verdeling en relatie met dat natuurlijk systeem meteen op. Echter het is zaak om daar ook een navolgbaar verhaal van te maken, dat hoofd- en bijzaken goed neerzet en relaties legt. Juist door dit gezamenlijk te doen en te verkennen ontstaat het gedeelde begrip.

Op de volgende pagina's worden een aantal kaarten gepresenteerd, die tijdens de preverkenning zijn gebruikt om de duiding van de relatie tussen het natuurlijk systeem en de diverse aspecten vanuit verschillende themavelden beter inzichtelijk te krijgen. Daarbij zijn ook combinaties gelegd tussen bepaalde aspecten en thema's. Bij de kaarten zijn de eerste observaties genoteerd.

Zoals gezegd, betreft dit een preverkenning en zal een uiteindelijke reeks gezamenlijk samengesteld moeten worden, op basis van een navolgbare opbouw en reeks op basis van urgenties, opgaven en bijbehorende aspecten. De conclusies die uit de kaarten getrokken worden, zullen ook gezamenlijk gedeeld en verdiept moeten worden. Op basis daarvan kunnen vervolgens weer nieuwe kaarten worden gegenereerd: van data naar informatie, van informatie naar inzicht en begrip. 


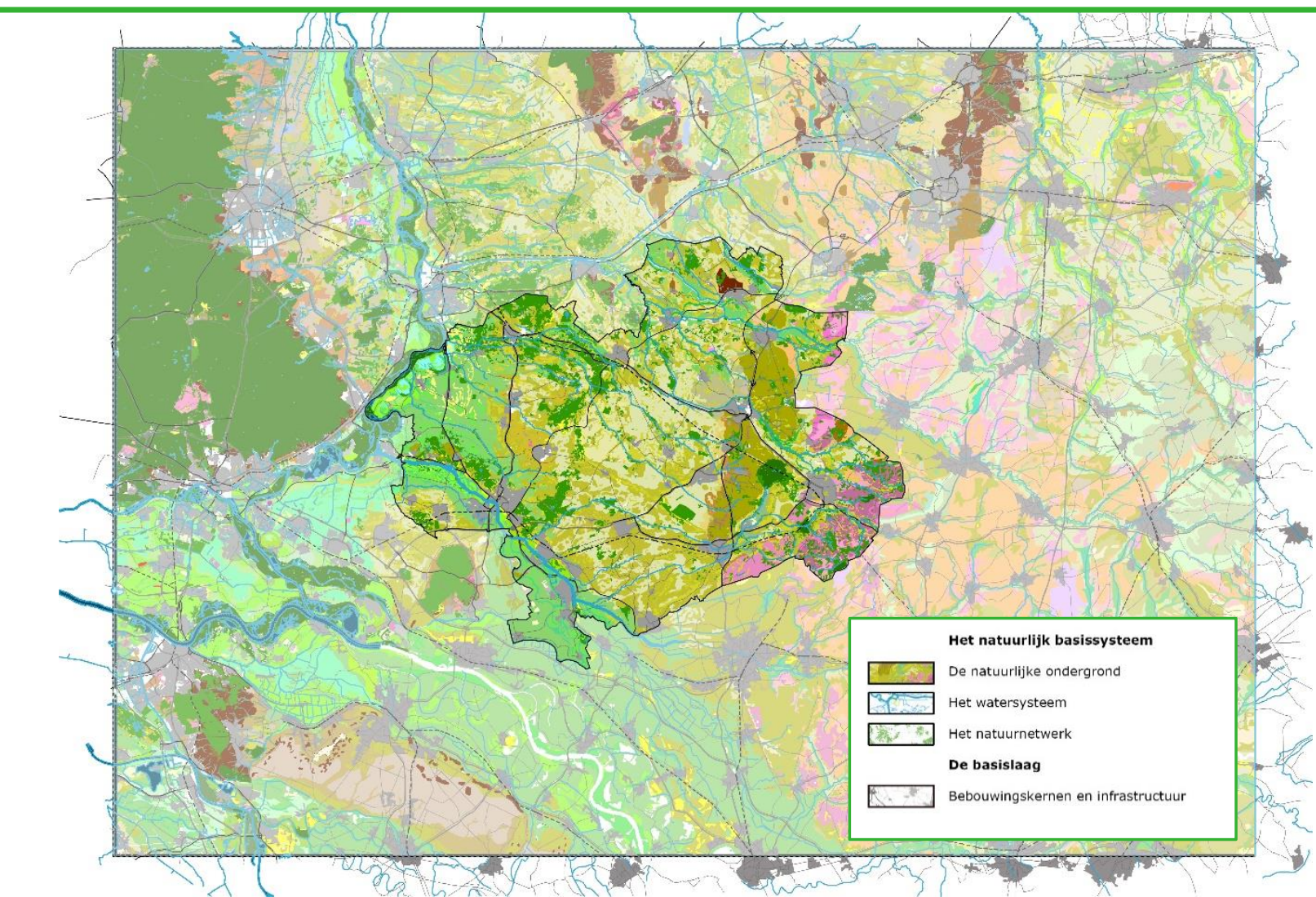

Figuur 7 Het natuurlijk basissysteem: bodem, water en natuur

\section{Het Natuurlijk basissysteem}

Het natuurlijk basissysteem bestaat uit de samenhang van het reliëf, de bodem, het watersysteem en de natuur. De kaart van het natuurlijk basissysteem is dan ook opgebouwd uit de geomorfologische kaart, de watersysteemkaart (hoofdwatersysteem) en de kaart van bestaande natuur. Ter referentie en herkenbaarheid is uiteraard de netwerklaag als basislaag daarop geprojecteerd.

Aangezien de 8RHK een grensregio is, maar het systeem niet ophoudt bij deze grens, zijn de beschikbare data over geomorfologie in Nederland en Duitsland bij elkaar gevoegd. Dit brengt al wel meteen uitdagingen mee naar voren, omdat andere eenheden en classificaties worden gebruikt. Waarschijnlijk zal dit ook het geval bij andere geodata die beschikbaar is bij de buren.

De kaart toont in één oogopslag de natuurlijke logica en deelgebieden in de regio, en de relatie naar buiten. Van oost naar west zien we daarin achtereenvolgens:

- het Plateau van Winterswijk, aan de westzijde -grotendeels begrensd door een van noord naar zuid uitstrekkend voormalig tunneldal (laagte);

- een zone van dekzandvlakten en dekzandruggen die zich van noord naar zuid opstrekt en ook duidelijke verschillen laat zien;

- het rivierengebied dat aan de zuid- en westkant het gebied omsluit.

Duidelijk zichtbaar is ook dat zowel de natuur als de netwerkpatronen (dorpen, steden en infra) veel van deze patronen volgen 


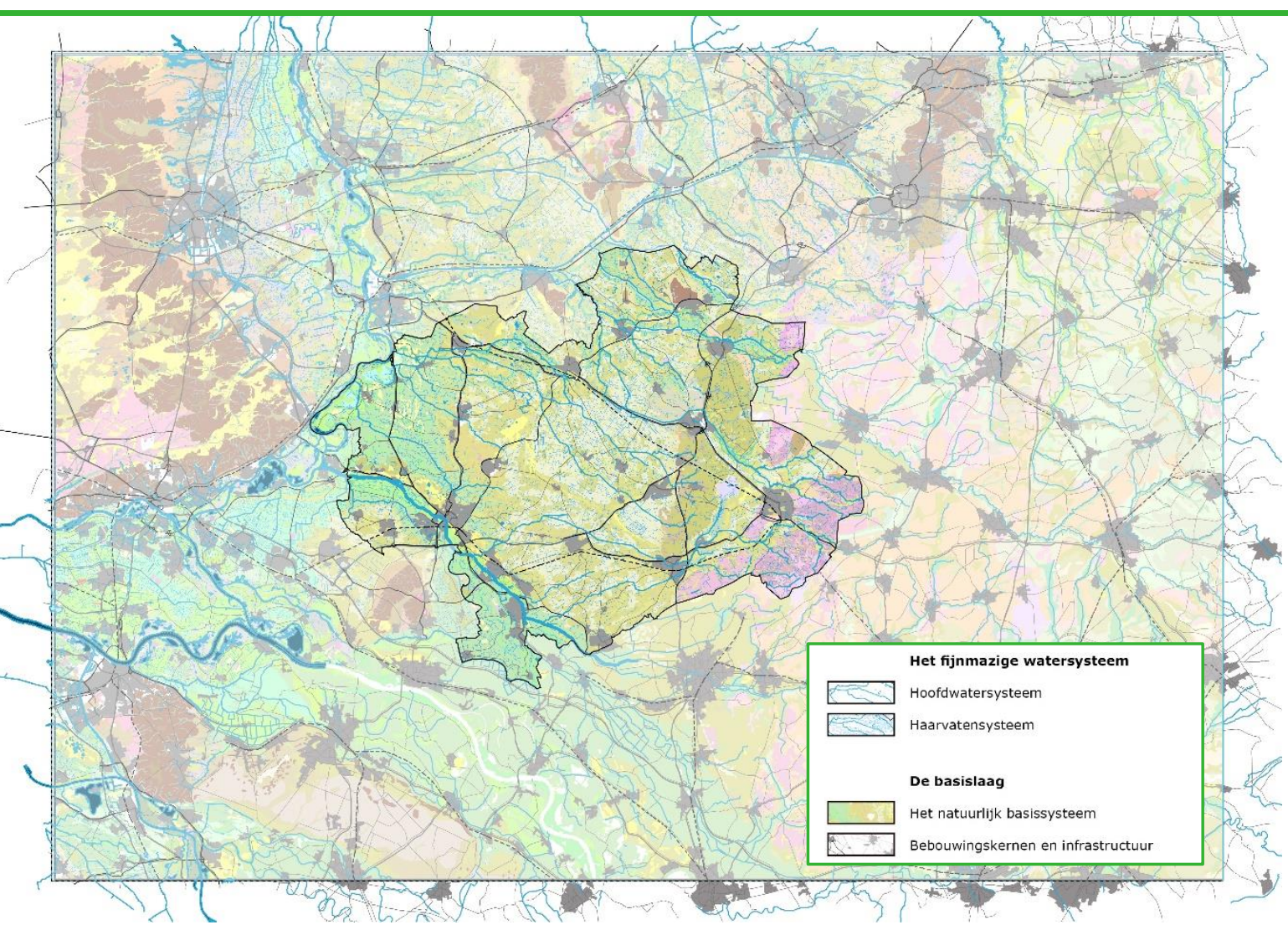

Figuur 8 Het fijnmazig watersysteem

Het fijnmazig watersysteem (boven) en de deelstroomgebieden (onder)

De kaart van het Natuurlijk basissysteem omvat alleen de hoofdwaterlopen, maar het is ook van belang de fijnmazigheid van het watersysteem inzichtelijk te hebben. De meeste hoofdwaterlopen en rivieren stromen vanuit Duitsland het gebied in. Alleen de Baakse beek ontspringt in het gebied. De kaart laat niet alleen zien hoe sterk het haarvatensysteem is ontwikkeld, maar legt ook de relatie tussen gebieden en het hoofdlopensysteem. Aanvullend hierop kunnen bijvoorbeeld ook de deelstroomgebieden geprojecteerd

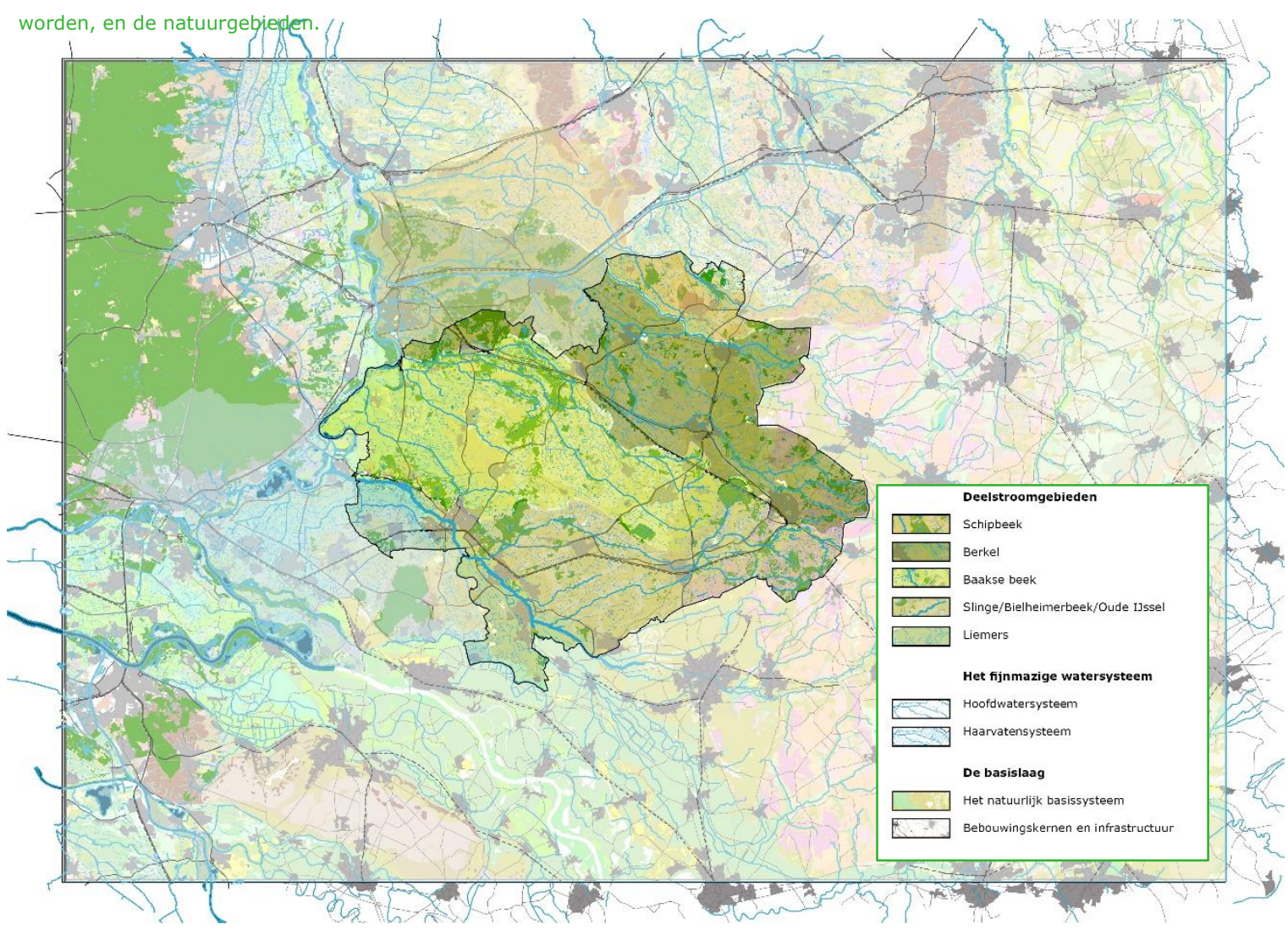

Figuur 9 Het fijnmazig watersysteem, deelstroomgebieden en natuurnetwerk 


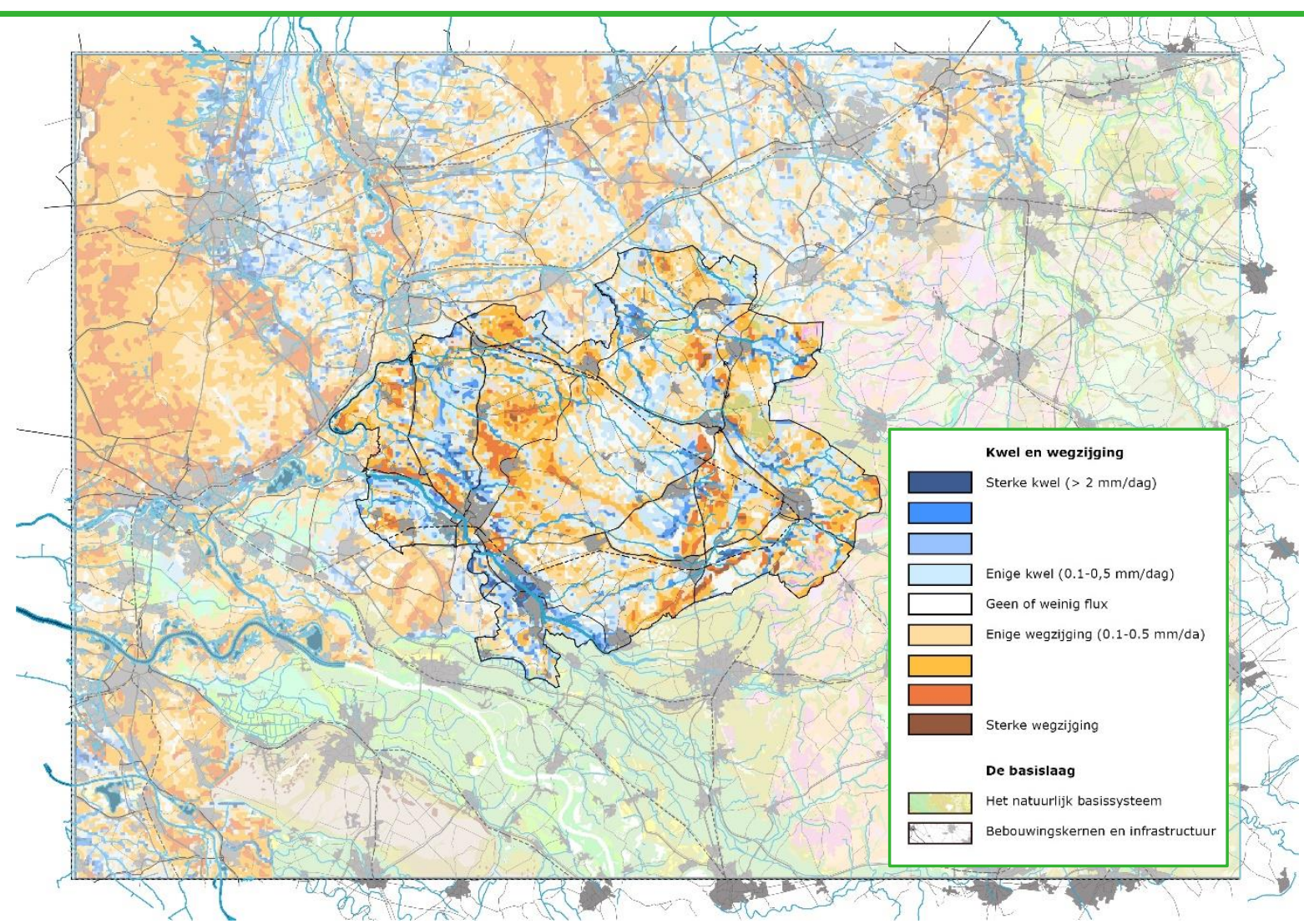

Figuur 9 Kwel en inzijging

Kwel en inzijging (boven) en het natuurnetwerk (onder)

Op de bovenstaande kaart is duidelijk de variatie te zien in kwel- en infiltratiegebieden en hoe de ruimtelijk variatie daarin nauw samenhangt met de natuurlijke basis. De relatie tussen het watersysteem, de ontwatering en de infiltratiegebieden is daarbij ook goed zichtbaar. Ook de projectie van het natuurnetwerk laat wederom de relatie met de natuurlijke basis zien, waarbij overgangszones er wel uitspringen, maar dat er voor de rest vooral nog sprake is van een verspreid patroon.

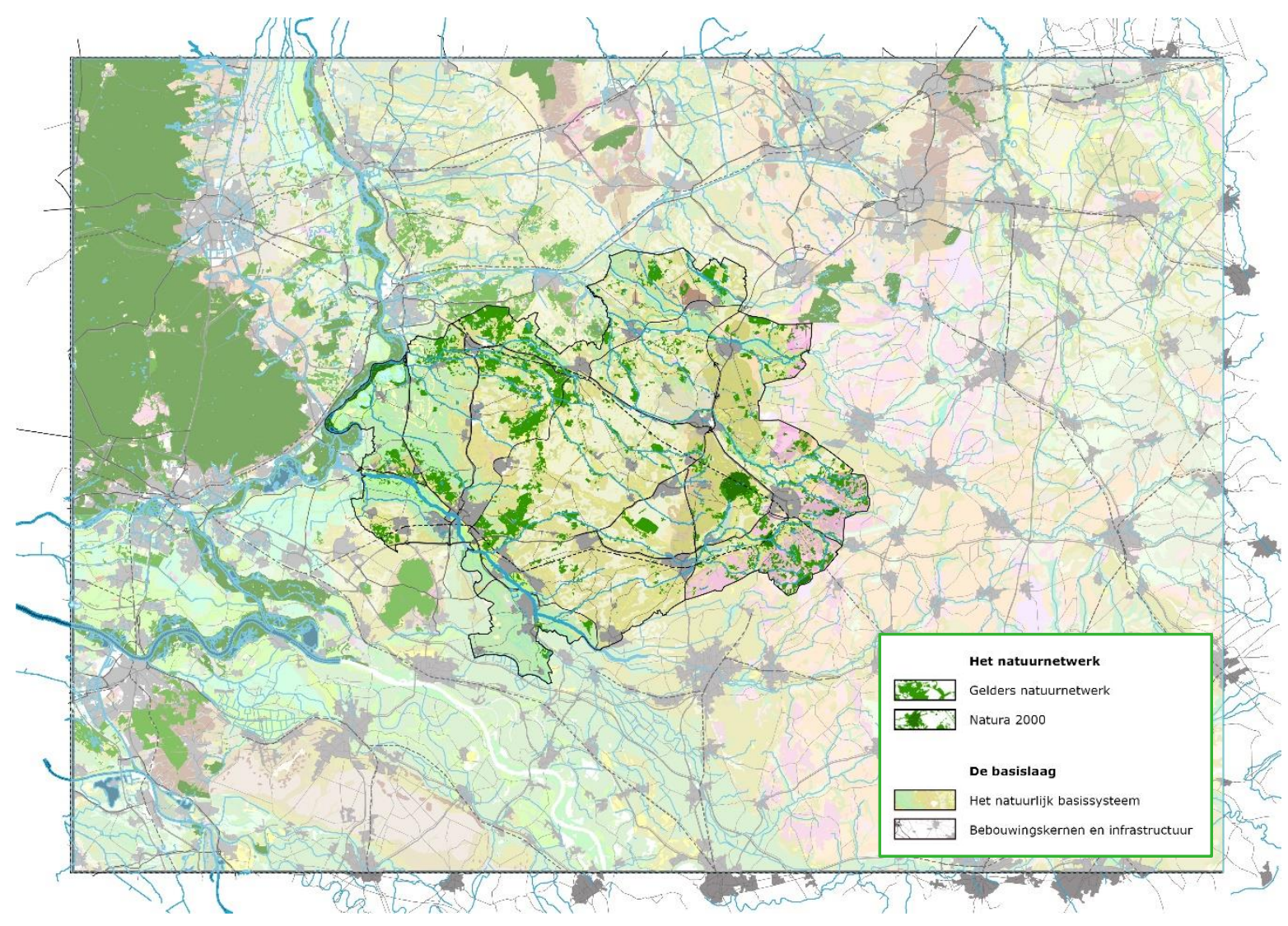

Figuur 10 Het natuurnetwerk 


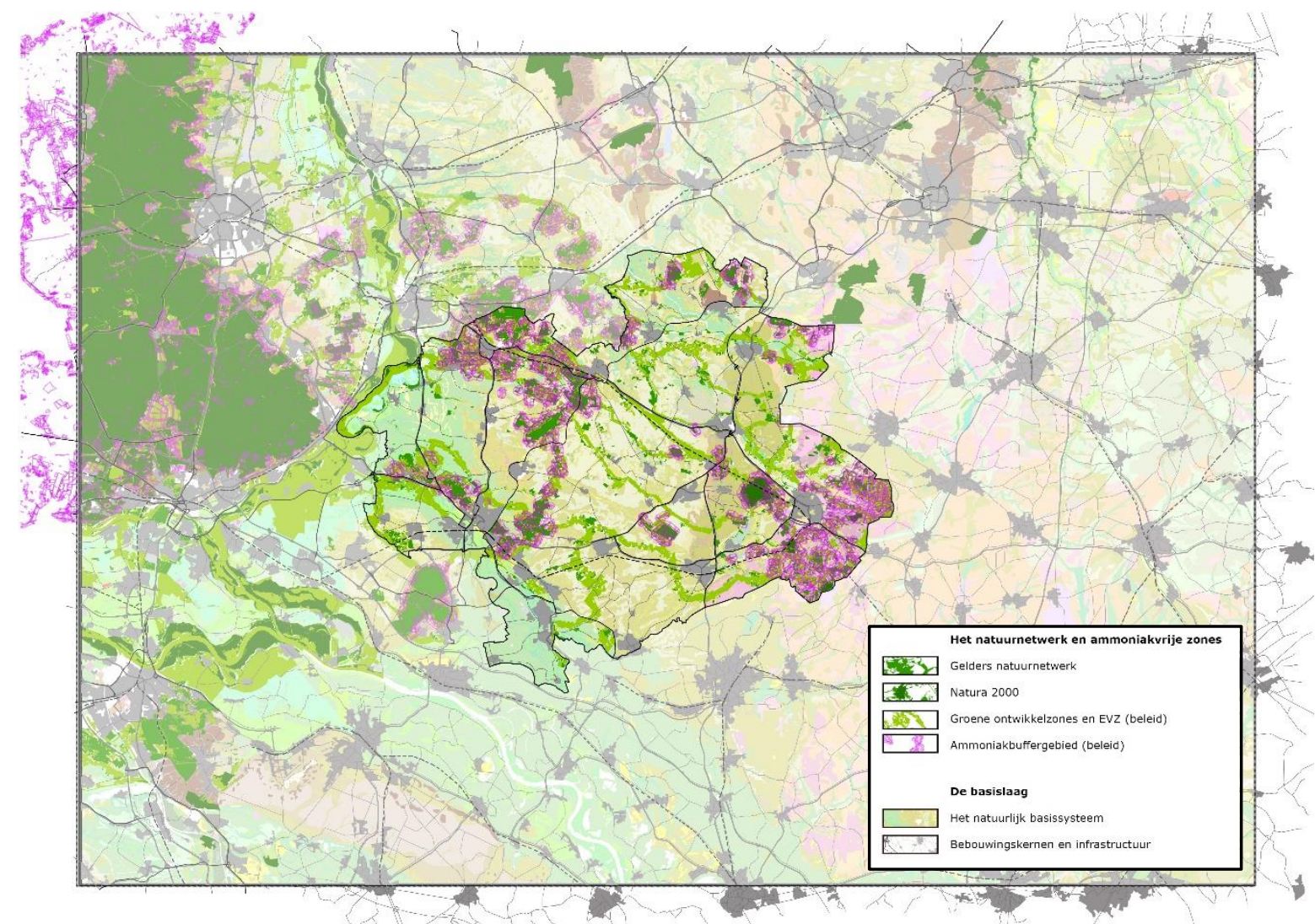

Figuur 11 Het natuurnetwerk en ammoniakvrije zones

Natuurnetwerk en ammoniakvrije zones (boven) en Stikstofdepositie (onder)

Stikstof en ammoniak hebben een significante invloed op de natuur. In het beleid zijn zogenaamde ammoniakvrije zones aangewezen, die weinig verrassend ook samenvallen met waardevol cultuurlandschap (Winterswijk) enerzijds en de natuurzone van noord naar zuid anderzijds. Kijken we echter naar de kritische stikstofdepositie dan valt op dat vooral het Winterwijkse Plateau en het Natura 2000-gebied de meeste overschrijding tonen. Wat de herkomst is laat deze kaart echter niet zien, terwijl dat net cruciaal is.

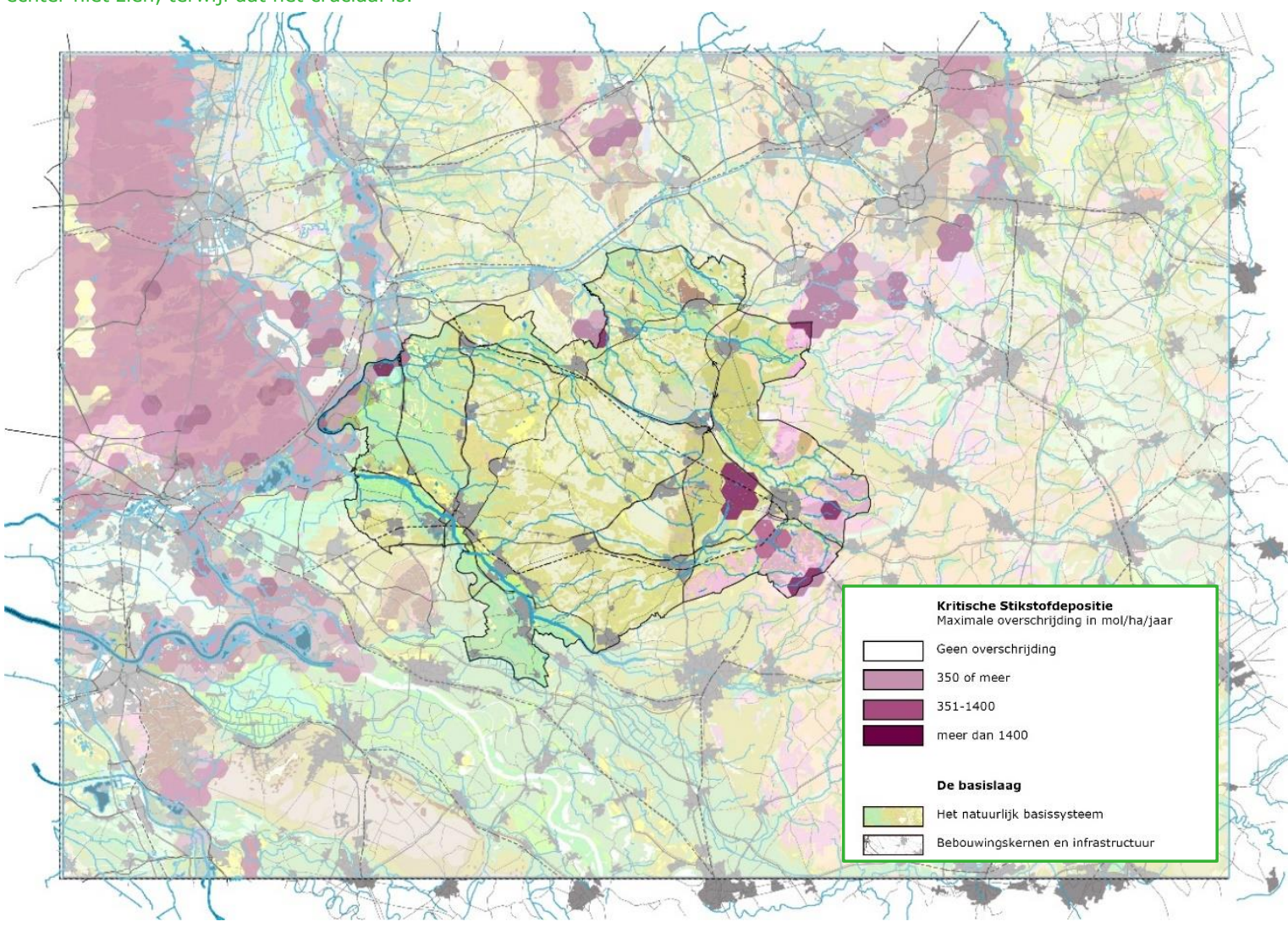

Figuur 12 Kritische stikstofdepositie 


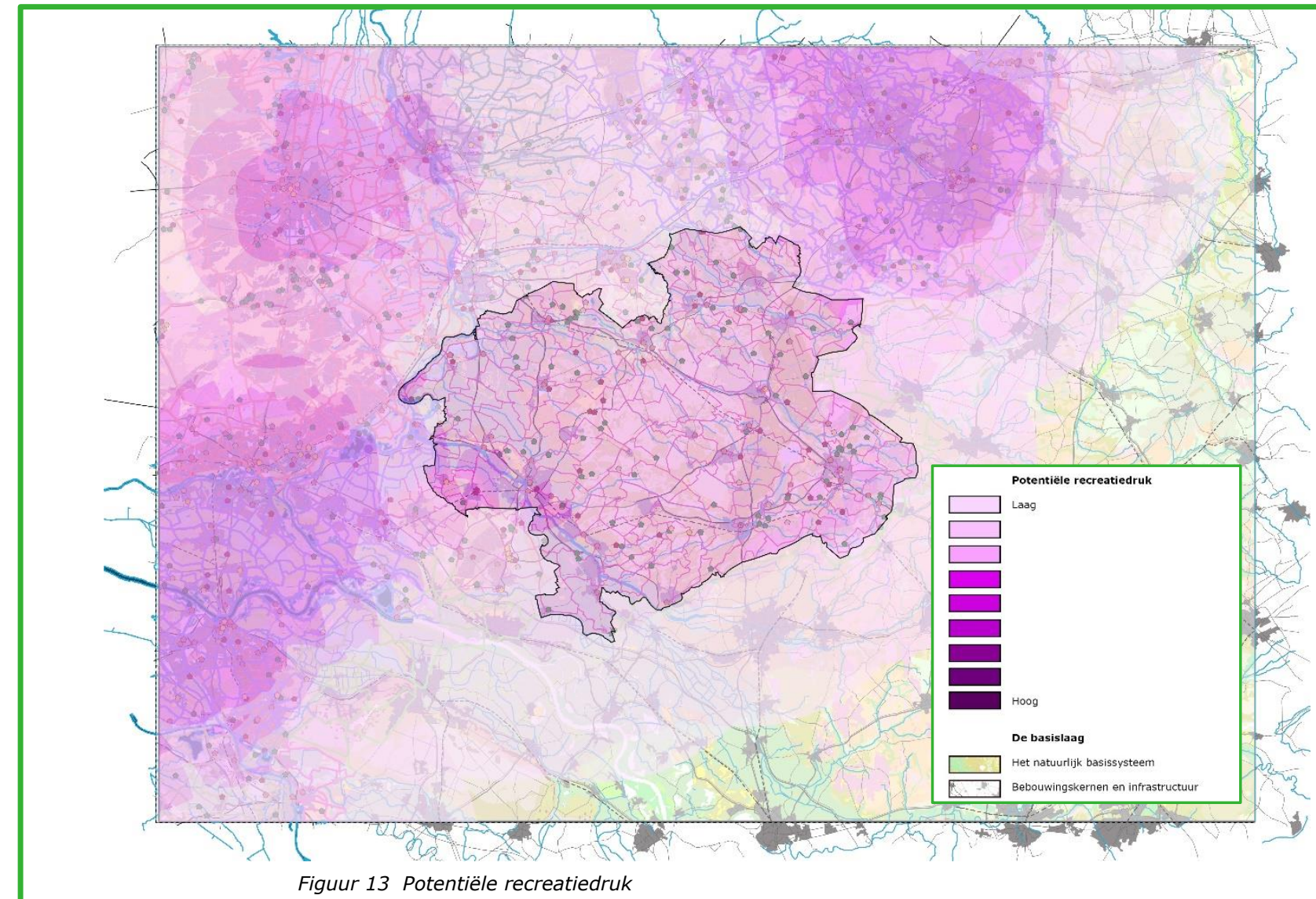

Potentiële recreatiedruk (boven) en Recreatienetwerk (onder)

De bovenste kaart laat de potentiële recreatiedruk zien, waarbij opvalt dat met name de zone rondom de IJssel en de Oude IJssel oplicht. Opvallend is dat het gebied verder redelijk egaal gekleurd is gelet op de talrijke verblijfsrecreatie en dagrecreatieve punten die aanwezig zijn. In het patroon van deze punten valt wel op dat er een onderscheid in de regio met een concentratie in de overgangszones van zand naar rivierengebied, de Berkel en het plateau.

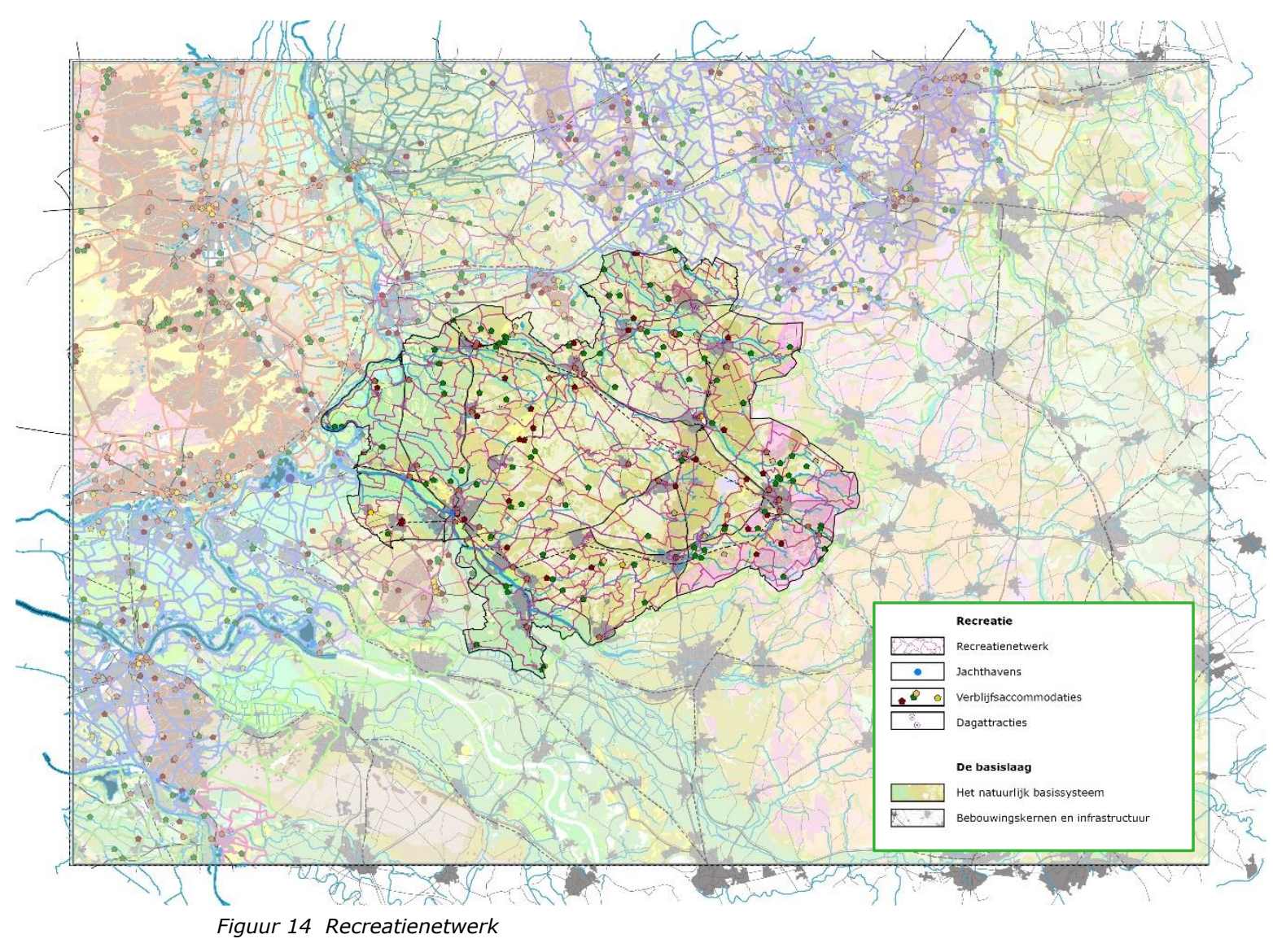




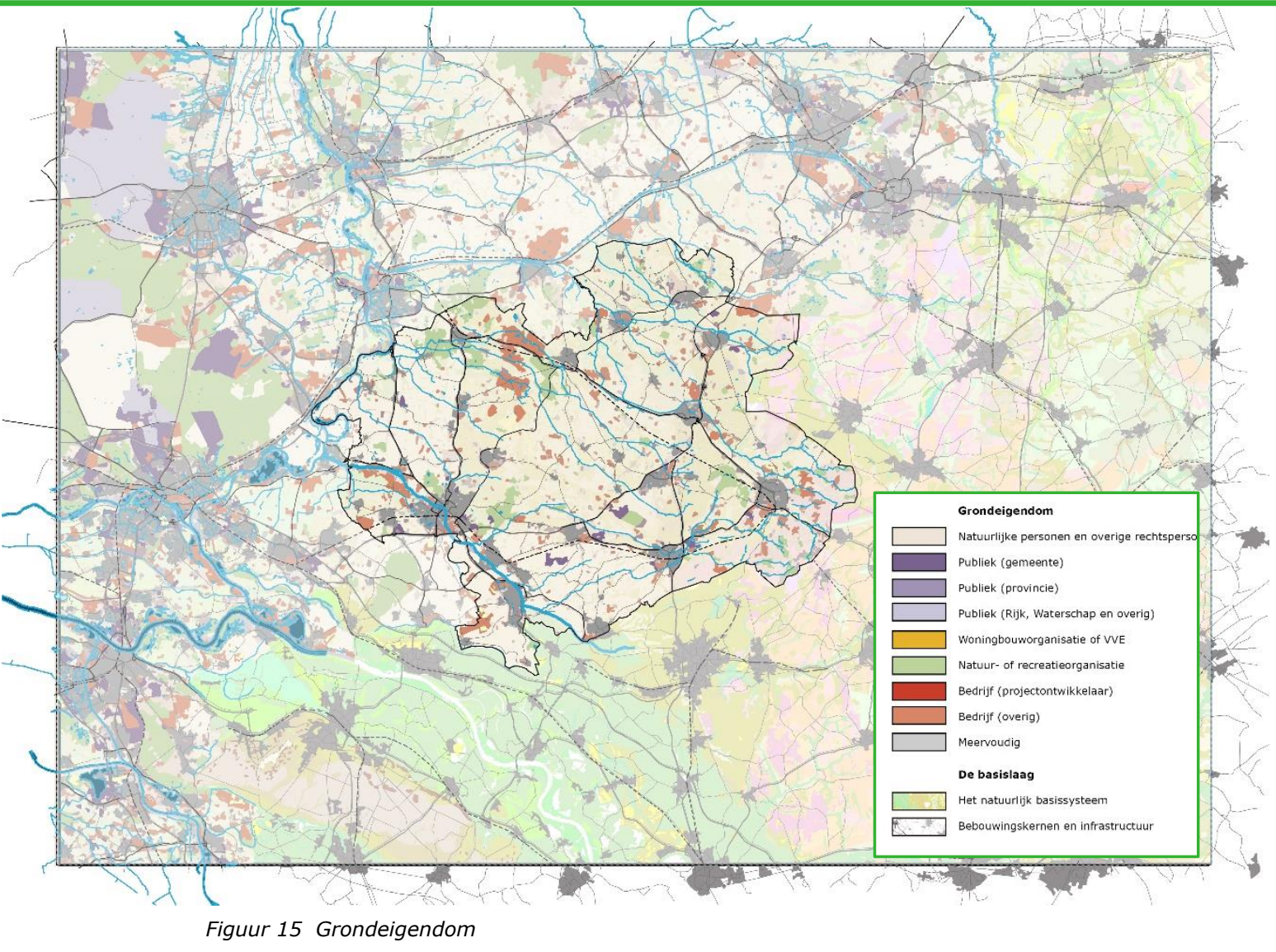

Grondeigendom (boven) en Landgoederen (onder)

De grondeigendommenkaart laat vooral zien dat er veel particulier bezit is. De eigendommen van natuurorganisaties liggen verspreid. Anderzijds laat de kaart met landgoederen duidelijk relaties zien met het eerder getoonde natuurnetwerk, alsook recreatienetwerk. Deze landgoederen liggen ook op specifieke plekken in het natuurlijk systeem.

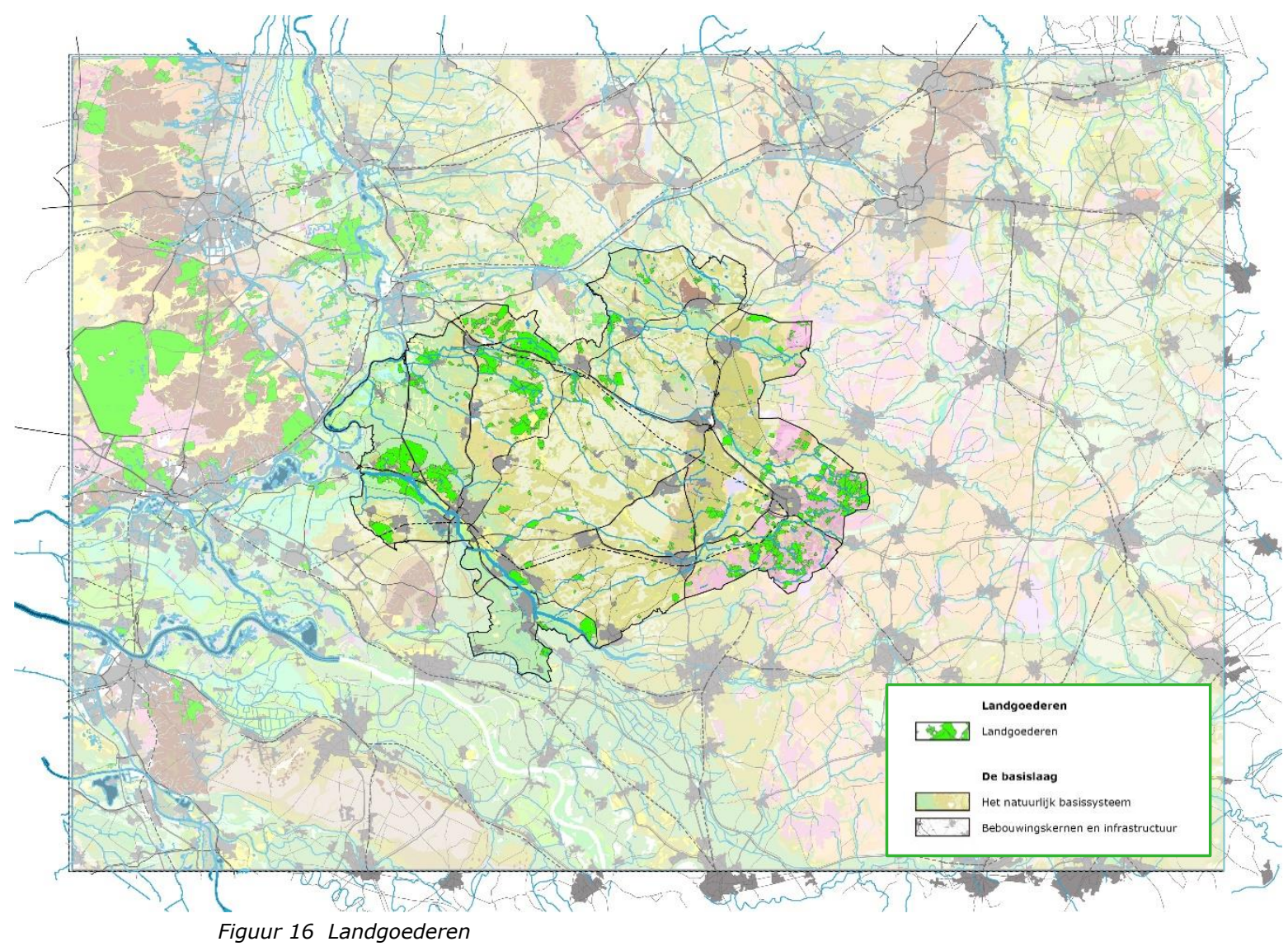




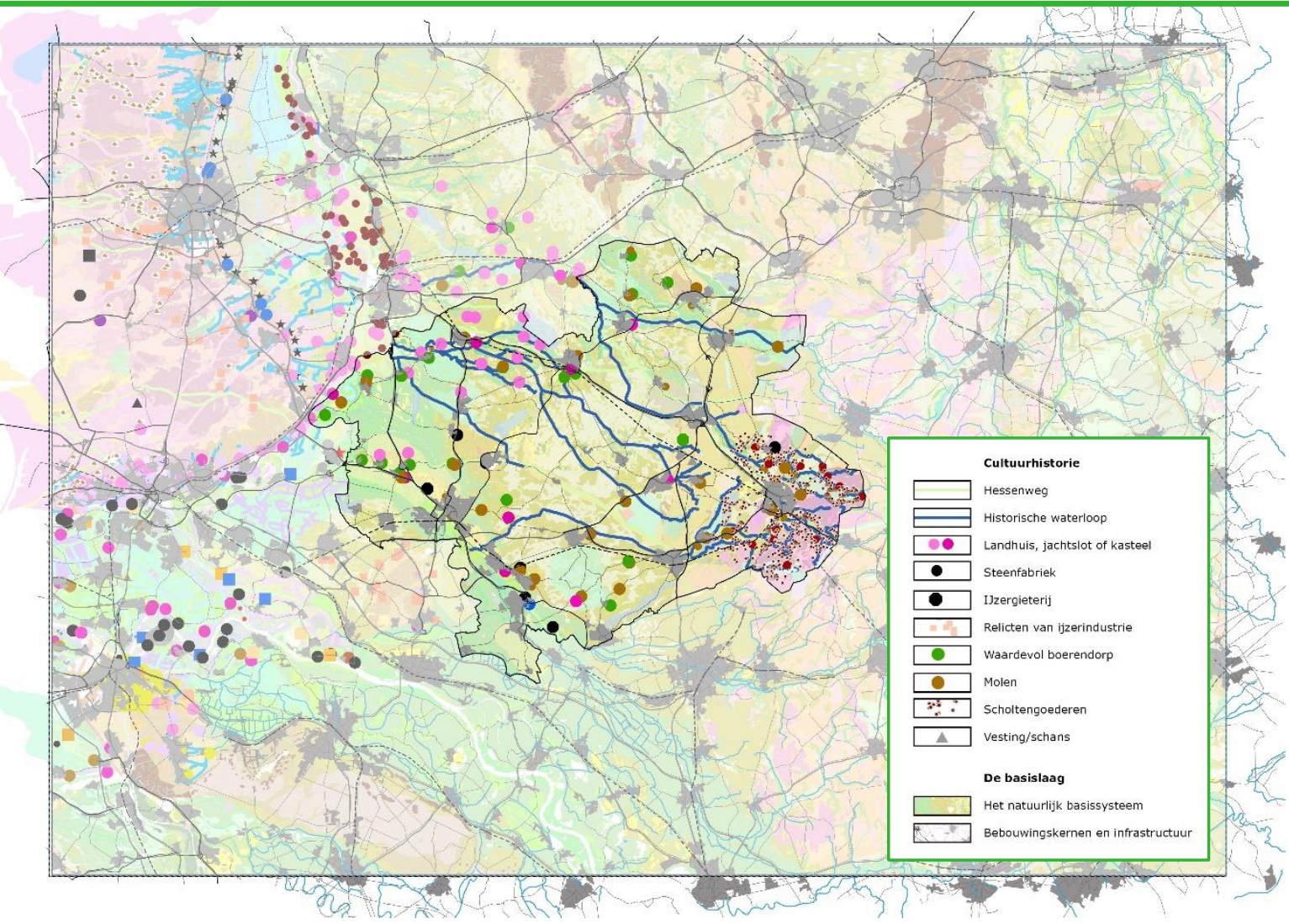

Figuur 17 Cultuurhistorie

Cultuurhistorie (boven)

Ook in het patroon van cultuurhistorische punten en netwerk valt op dat bepaalde gebieden er beduidend uitspringen. Ook de aard van de cultuurhistorische punten verschilt daarbij. Dit lijkt ook duidelijk samen te vallen met de natuurlijke basis. Interessant is ook dat diverse waterlopen aangemerkt zijn als historische waterlopen. 


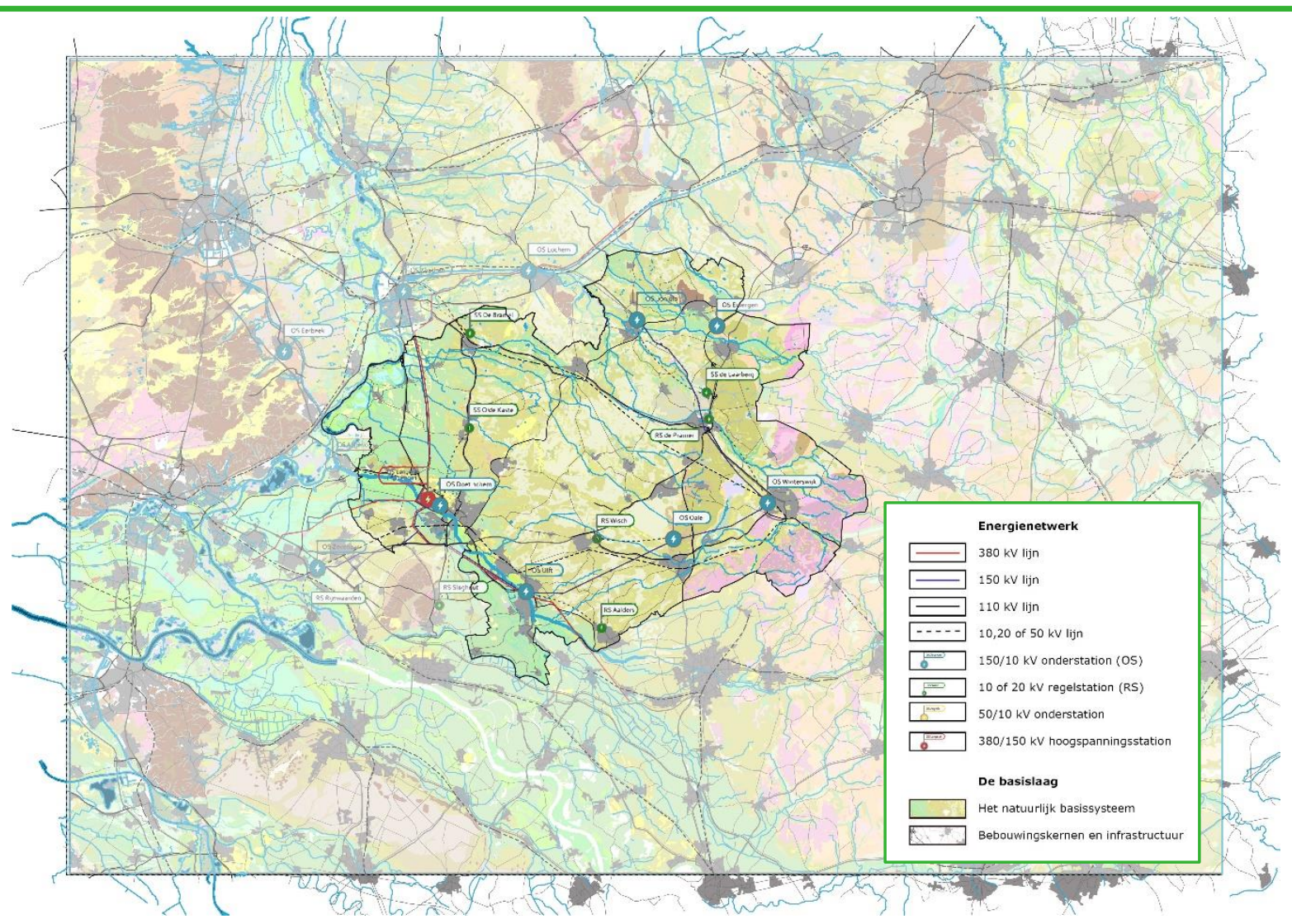

Figuur 18 Energienetwerk

Energienetwerk (boven) en Capaciteit teruglevering (onder)

Het energienetwerk volgt uiteraard het netwerk van dorpen en steden. Het valt daarbij op dat ook daar enige relatie zichtbaar is met de natuurlijke patronen en wederom het 'middengebied' gevrijwaard is. Wat vooral opvalt is het grote verschil in transportcapaciteit en daarmee mogelijkheden voor teruglevering. Deze hangt los van het natuurlijk systeem, maar vooral met de voorzieningen. Het legt wel een basis voor mogelijke capaciteit uitbreiding via wind- zonne-energie.

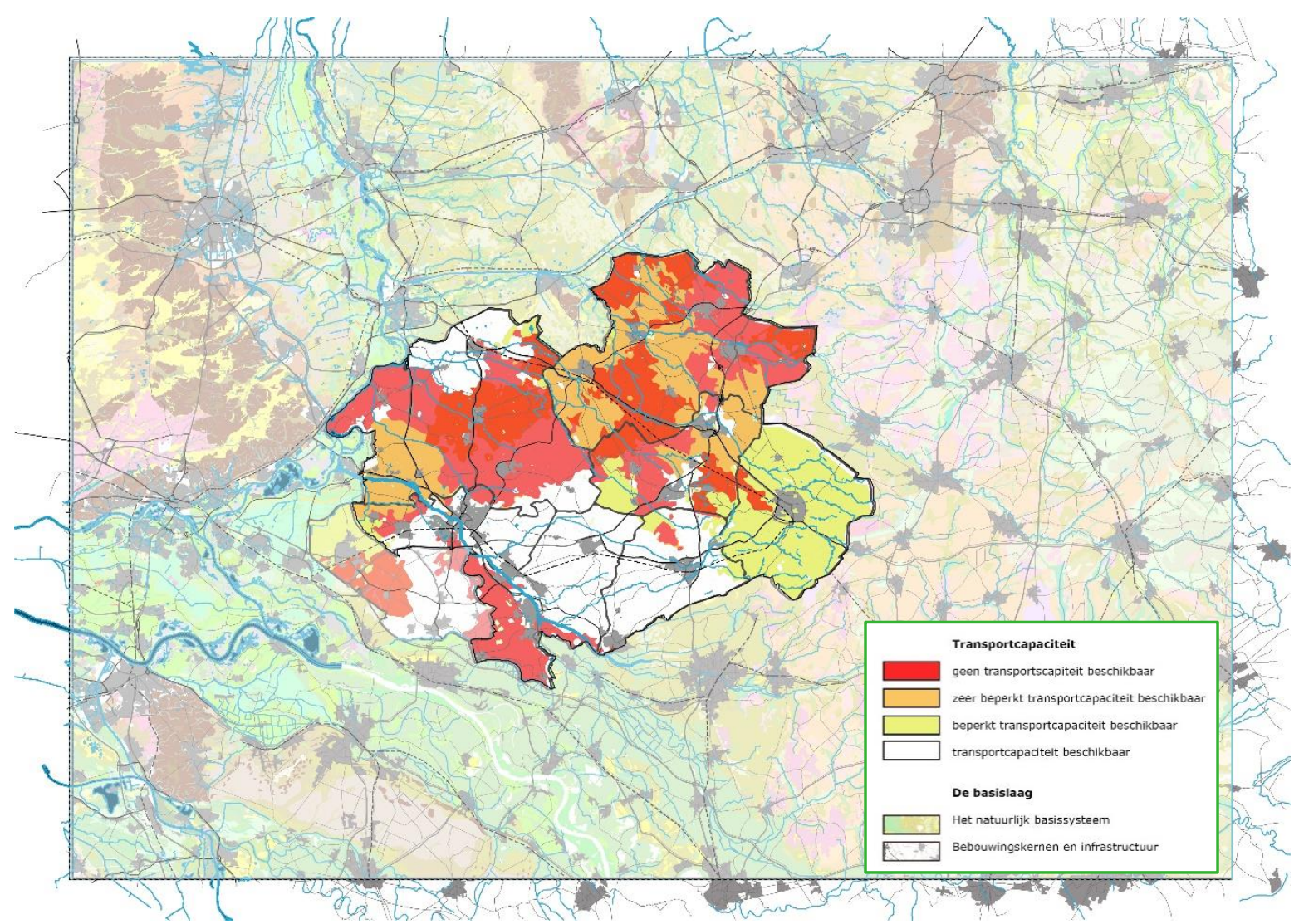

Figuur 19 Capaciteit teruglevering energie 


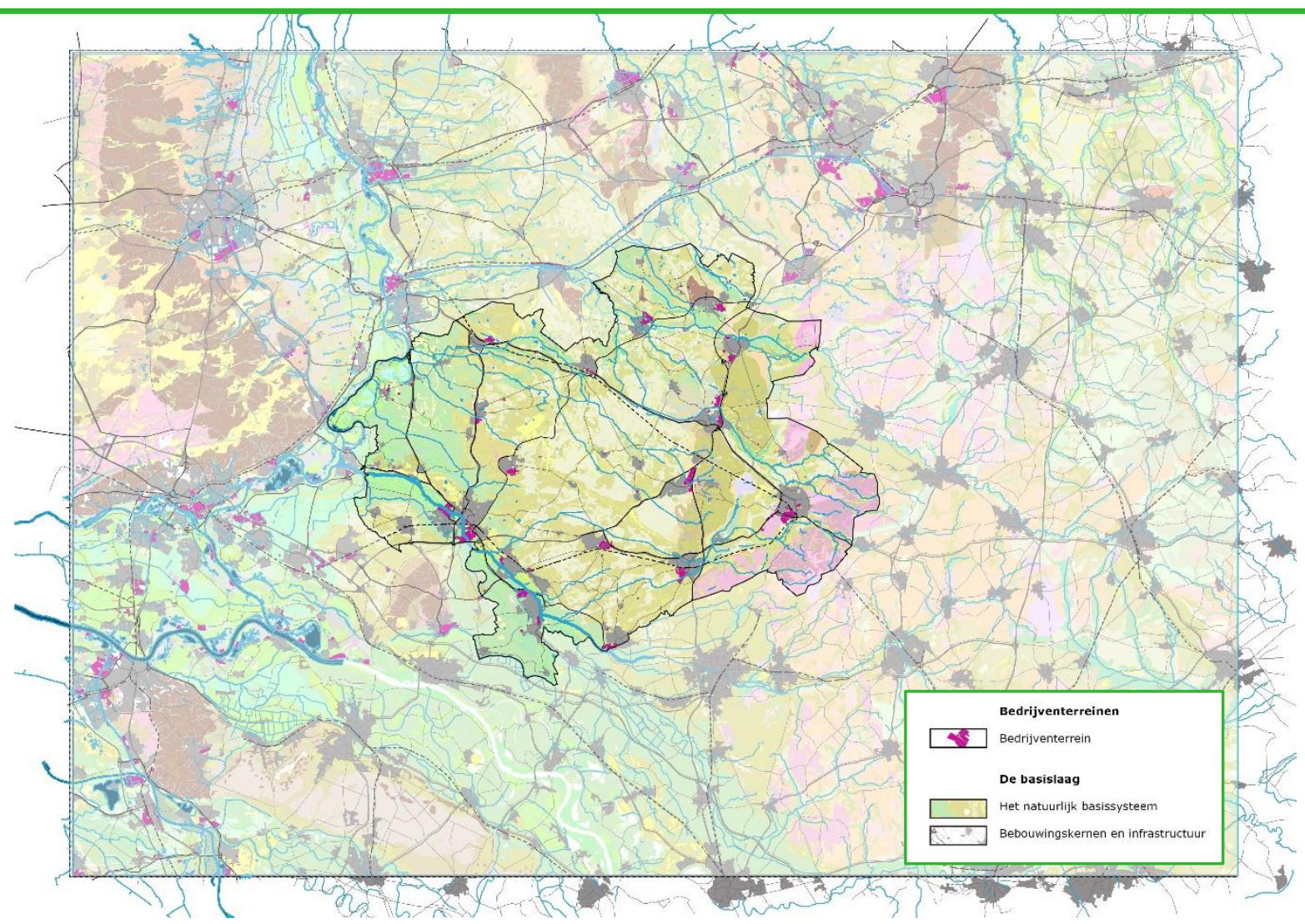

Figuur 21 Bedrijventerreinen

Bedrijventerreinen (boven) en Wijktypologieën (onder)

De bedrijventerreinen concentreren zich vooral rond de bestaande kernen, met een duidelijke relatie met de infrastructuuur. Er zijn op het eerste oog nog geen duidelijke concentraties of zwaartepunt. Qua wijktypologieën laat het gebied een kenmerkend beeld zien, waarin naast de oudere kleinere kernen, een aanzienlijk deel van het woningaanbod verrassend genoeg uit naoorlogse nieuwbouw bestaat; de zogenaamde bloemkoolwijken.

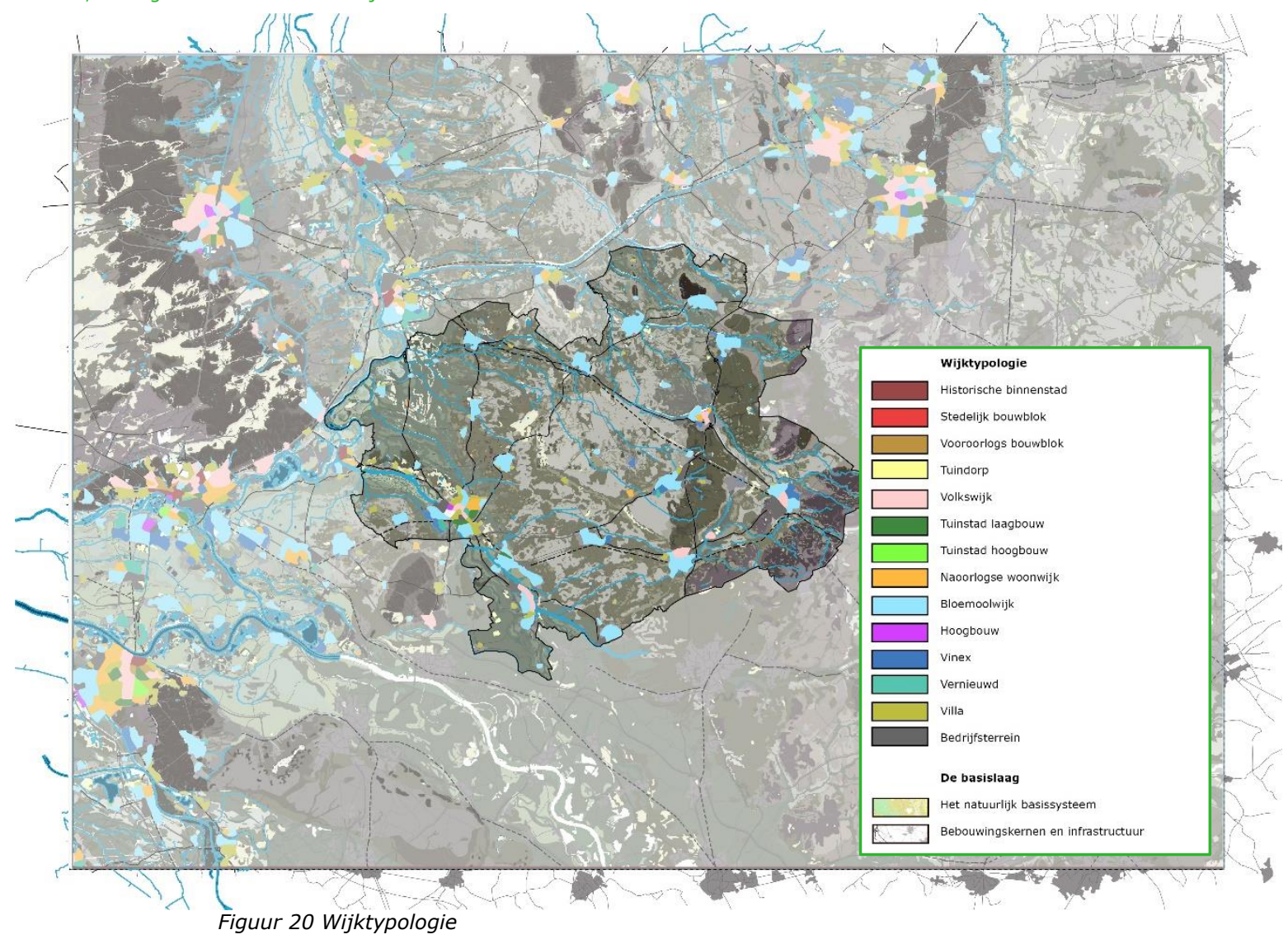


De voorgaande kaartenreeks is een eerste verkenning, waarop vooral ook op doorgegaan moet worden. Wat zien we nu eigenlijk en wat zou nog meer relevant zijn om het inzicht te verbeteren. Een voorbeeld daarvan is bijvoorbeeld de opbouw rond de droogteproblematiek. Door het verhaal te vertellen over het watersysteem, het watergebruik en dat te relateren aan enerzijds de feitelijke landbouwkundige droogte en anderzijds de daadwerkelijke droogteschade wordt het verhaal scherper en verbanden beter gelegd binnen de problematiek.

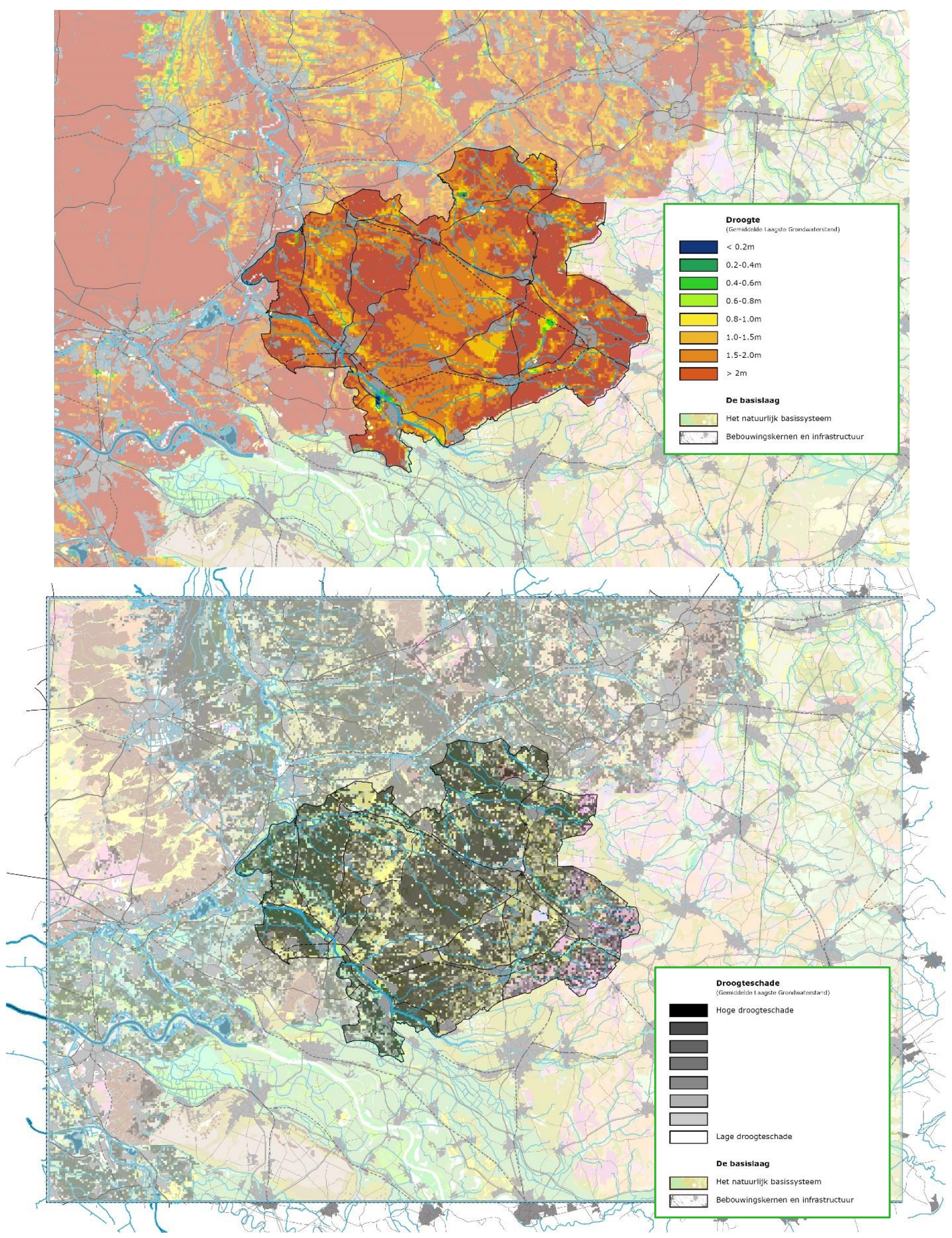

Figuur 22 Droogte (Gemiddelde Laagste Grondwaterstand) (boven) en droogteschade (onder)

Twee beelden leggen de urgenties wellicht anders. Door deze inzichten te combineren met het natuurlijk systeem van bodem en water, maar ook met de landbouwstructuur ontstaat pas een compleet beeld en verhaal 
Ook het beleid laat zich regelmatig vertalen op kaart. Deze kaartprojecties hebben we uiteindelijk op het natuurlijk systeem gelegd om te zien hoe deze wel of niet aan de basis staat van beleidskeuzen. Daarbij valt als snel de diversiteit in detail op, maar vooral ook het ontbreken van een duidelijke link met de natuurlijke basis of daaruit voortvloeiende deelgebieden. De vraag is of daarmee kansen worden gemist; de verwachting is van wel. Alleen in het water- en natuurbeleid is deze link vooralsnog het sterkst.

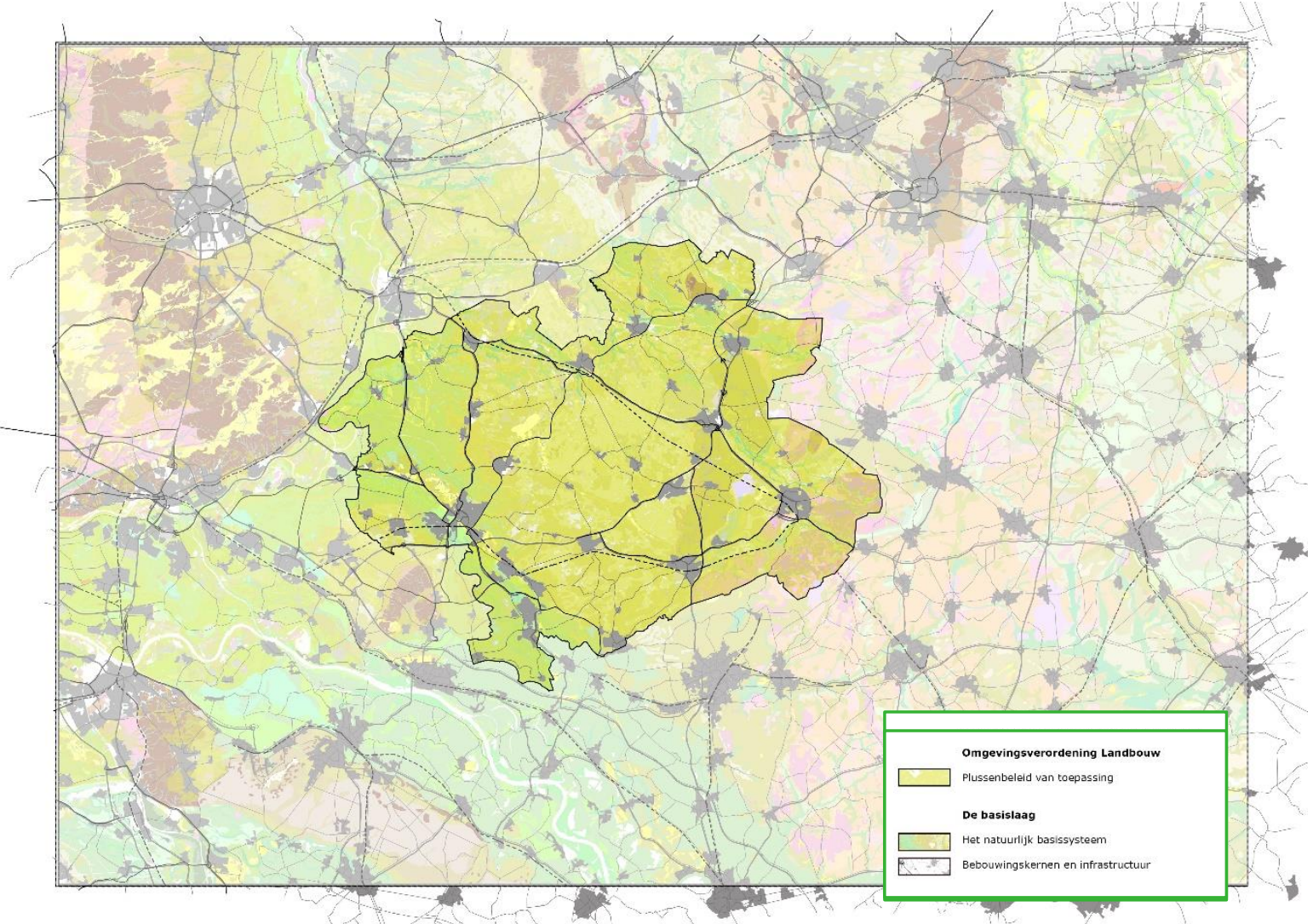

Figuur 23 Het plussenbeleid

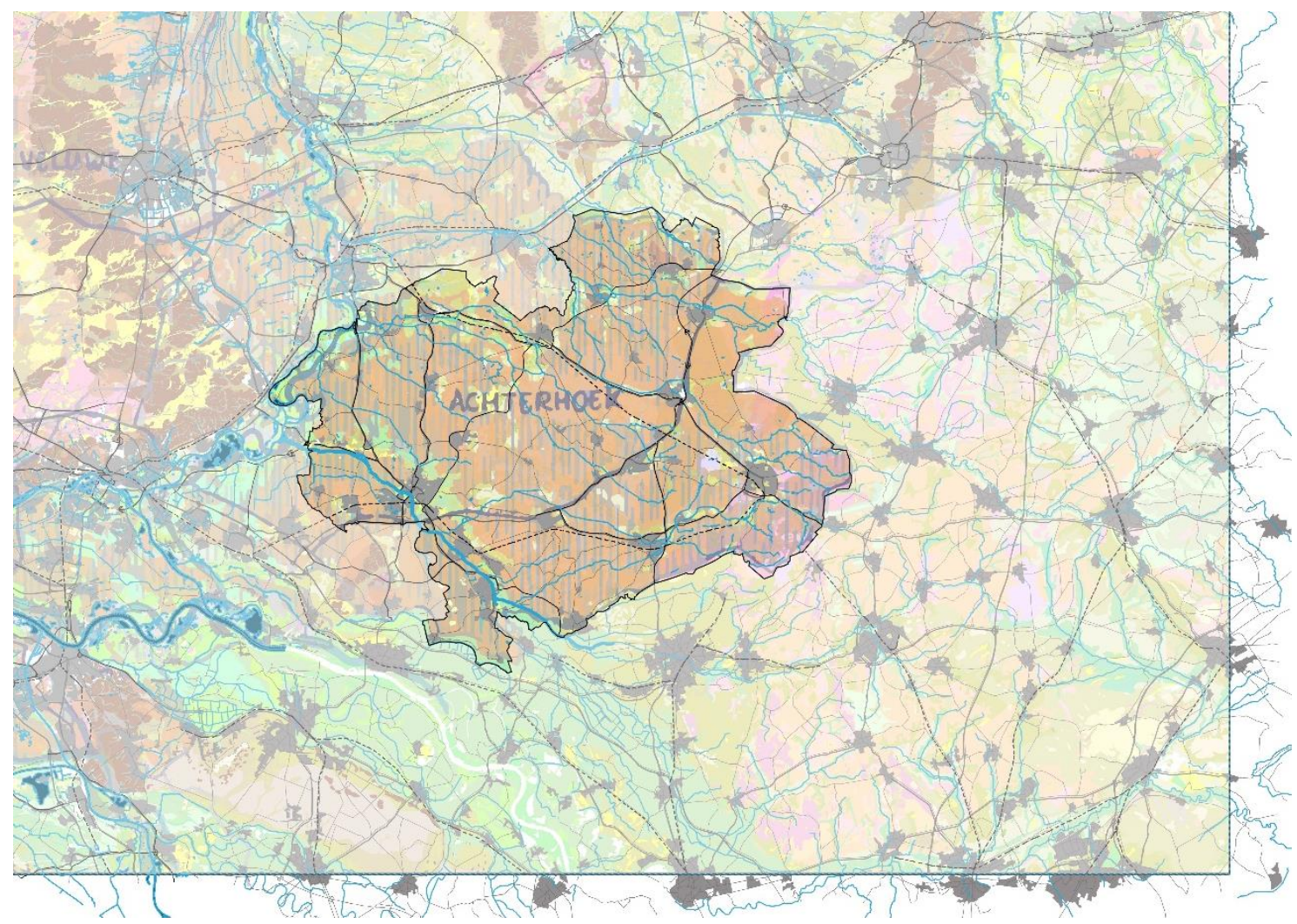

Figuur 24: Het energiebeleid 


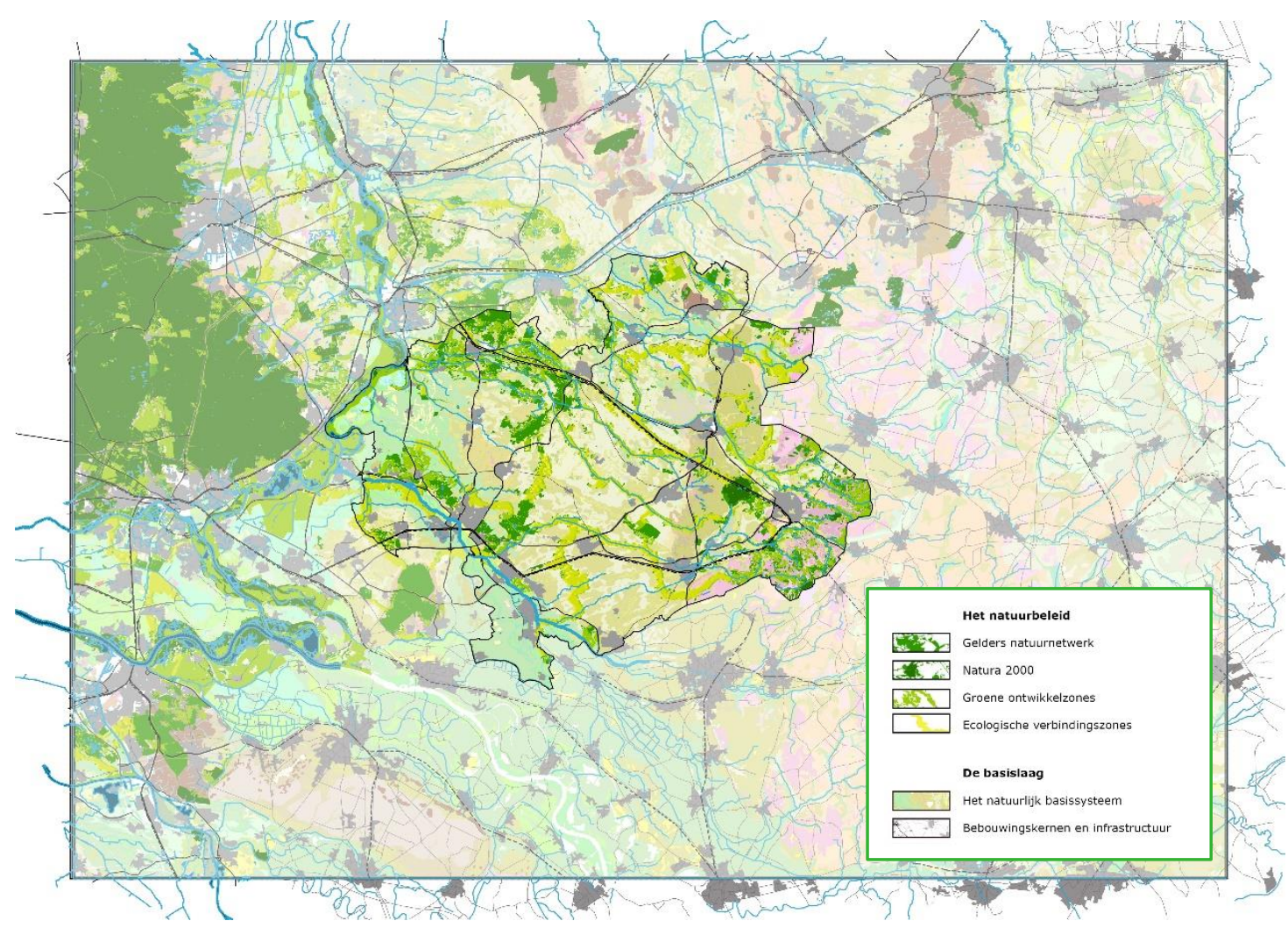

Figuur 25: Het natuurbeleid 


\subsection{O'orzaak-gevolg analyse}

Een waardevolle ondersteunende methode om de complexiteit te doorgronden en de verbanden en samenhang samen te ontdekken is de oorzaak-gevolg analyse ('causal chain analysis').

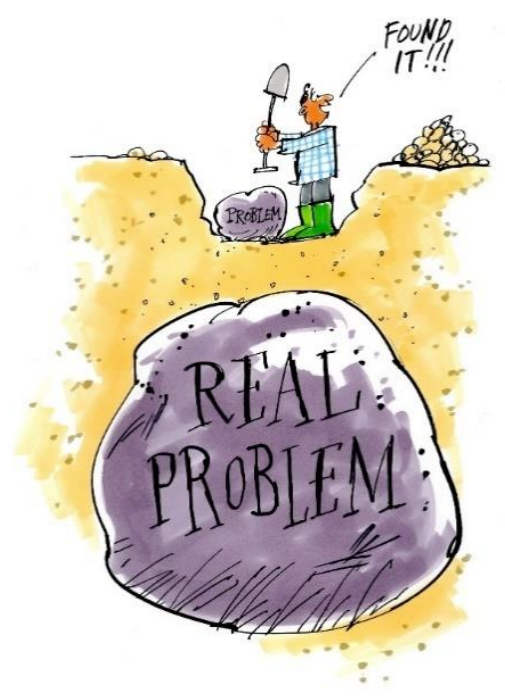

Figuur 26: Het probleem achter het probleem (cartoon Geert Gratama)

Door deze gezamenlijk uit te voeren ontstaat verdieping, maar vooral gezamenlijk inzicht in de relaties en dwarsverbanden, maar ook in de koppeling tussen het fysieke, het sociale en het beleid.

Een dergelijke analyse geeft ook beter inzicht op de effectiviteit en houdbaarheid van strategieën en maatregelen.

De 'oorzaak-gevolganalyse', wordt in het Engels ook vaak aangeduid als 'Root Cause Analysis' waarin tot uitdrukking komt dat het uiteindelijke doel is om de dwarsverbanden te ontdekken, maar vooral ook om de onderliggende problemen (hoofdproblemen) beter te doorgronden. Hoe 'dieper' je graaft, des te duidelijker het vaak wordt waar het echte probleem zit. En juist door die problemen aan te pakken bereik je meer. Meer dan dat je de directe effecten aanpakt. Deze 'oorzaak-gevolganalyse' biedt een geordende systematiek, waarbij de vragen 'Waarom?' en 'Wat meer?' telkens gebruikt worden om de causale keten verder te verdiepen en uit te bouwen.

Ter illustratie is een voorbeelduitwerking gemaakt rondom het fenomeen droogte (figuur 27). Door telkens de vragen te stellen 'waarom?' en 'wat meer?' ontstaat al snel een eerste causale keten. Daarbij moet uiteraard opgemerkt worden dat dit een voorbeeld betreft en dat in een interactief proces met kennisdragers een aanmerkelijke grotere keten zal ontstaan met nog meer dwarsverbanden.

Wij nemen u mee in de gedachtenlijn van deze voorbeelduitwerking. Beginnend met het fenomeen droogte, stellen wij ons de eerste twee vragen: 'Waarom is droogte een probleem en voor wie en wat?' en 'Waarom is er sprake van droogte?'.

Op de eerste vraag ontstaat al snel een breed palet aan mogelijke effecten van droogte voor zowel landbouw, water, natuur en maatschappij. Hoe specifieker je de effecten maakt, hoe beter je vervolgeffecten ook weer kunt ontrafelen. Zo kun je stellen dat droogte leidt tot verdroging van de natuur en bodem, wat weer kan leiden tot een groter risico op natuurbrand of juist wateroverlast bij extreem weer in deze drogere periode. 
Gaan we in op de tweede vraag, dan wordt al snel geroepen dat klimaatverandering de grote oorzaak is van droogte. De vraag kan dan ook meteen gesteld worden wat je daar nu meteen aan zou kunnen doen en hoe dat effect voorsorteert op de korte termijn. Het is dan van belang om ook te kijken welke tussenstappen er te vinden zijn tussen klimaatverandering en daadwerkelijke droogte. Zo lijkt de klimaatverandering die al gaande is te leiden naar grotere variabelen in neerslagpatronen en neerslagtekorten, met name in het voorjaar en de zomer. Maar jaarrond blijft het redelijk stabiel. Dus er zijn andere zaken relevant die maken dat er uiteindelijk van droogte sprake is. Denk daarbij aan waterverbruik, de inrichting (en het bufferend vermogen) van het watersysteem, de mate van verdamping door bepaalde gewastypen of natuur- en bostypen en de bodemkwaliteit. Die inrichting en gebruik komt weer voort uit hoe we tegen ons natuurbeleid of onze voedsel- en landbouwstrategie aan kijken en de keuzen die we daarin hebben gemaakt. Willen we daar in wijzigen dan zijn we afhankelijk van de achterliggende gedachten en verbanden daarin. En zo kom je van droogte al snel in tal van domeinen en achterliggende patronen van oorzaak en gevolg.

De plaats waar je in de keten je interventies doet, maakt ook hoeveel effect je daarmee voorsorteert. Stel je voor dat je een maatregel aan het eind van de keten neemt, neem meer brandweer of betere uitrusting om natuurbranden te bestrijden, dan los je uiteindelijk het probleem niet op en blijf je bezig. Echter als je verderop in de keten maatregelen neemt om de verdroging van de natuur tegen te gaan en de inrichting te verbeteren, zodat je de schaal beperkt houdt, behaal je al meer resultaat. Maar op die verdroging van de natuur echt tegen te gaan zul je uiteindelijk naar je watersysteem en het bufferend vermogen moeten kijken... en die maatregelen hebben ook positieve effecten op bijvoorbeeld de landbouw, de drinkwatervoorziening en dergelijke.

Kortom, een oorzaak-gevolganalyse helpt om de verbanden te zien en strategieën en maatregelen beter te kunnen plaatsen en beoordelen. Deze oorzaak-gevolganalyse kan gebruikt worden als basis om vervolgens met (gevalideerde) data dit verder in beeld te brengen en uit te werken.

\section{Deep dive toont effectiviteit maatregelen} en cross-sectorale connecties

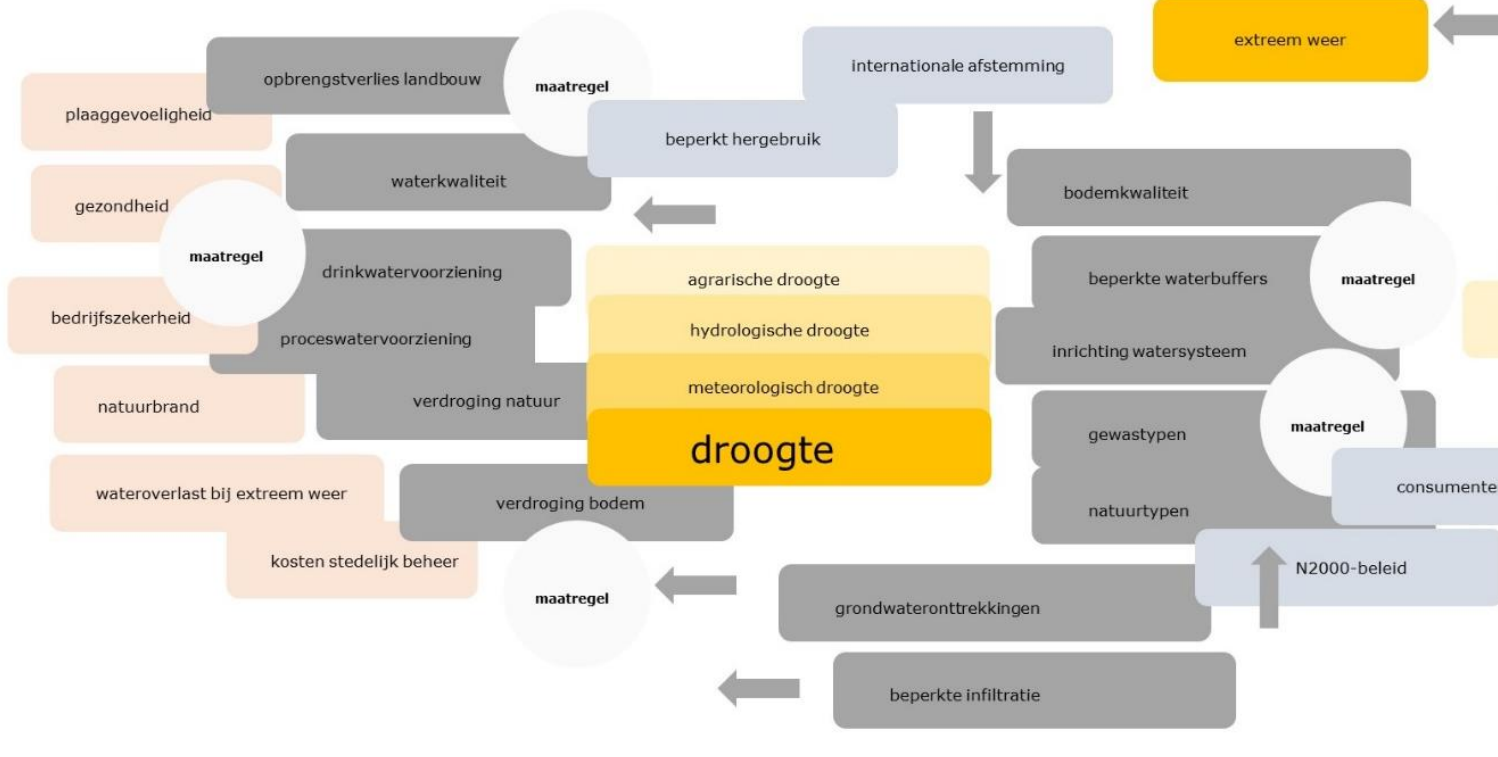

inspiratie DROOGTE

Figuur 27: Een voorbeelduitwerking oorzaak-gevolganalyse 


\subsection{Integraal (wat moet) en sectoraal (wat kan)}

Integrale planvorming vraagt ook om een flexibele aanpak. Alles met alles verbinden, betekent niet per definitie dat altijd alles met iedereen gedaan hoeft te worden, mits...

Het vergt echter wel nieuwe vormen van governance, ontwerp- en planningsaanpak en vaardigheden. De transities en majeure opgaven vragen enerzijds om flexibiliteit, maar anderzijds ook om richting en inspirerend beleid dat mogelijk maakt. Zoals eerder al gezegd rondom het construeren van de verhaallijn geldt ook hier dat slim moet worden ingespeeld op de verschillende motieven, belangen en perceptie. Wat beweegt een ieder tot daadwerkelijke handelen en veranderen? (Otto, 2020) Op de verschillende schaalniveaus zal geborgd moeten worden dat een en ander aansluit en op elkaar voortbouwt.

De analogie naar vlechtende rivieren kan getrokken worden, waarbij een overkoepelend landschap geschetst kan worden met diverse sectorale lijnen die samen een dynamisch geheel vormen.

Duidelijke principes liggen ten grondslag en worden gedeeld, maar de daadwerkelijke route is open en biedt ruimte aan specifieke invulling op basis van de lokale omstandigheden. Op basis van een gedeeld begrip en perspectief kunnen separate sectorale uitwerkingen worden gemaakt, die tussendoor weer terugvloeien en het gezamenlijk perspectief bijstellen, herijken of versterken (De Rooij, 2021). Zoals gezegd, vraagt dit om een regie, maar biedt ook volop ruimte voor maatwerk. 


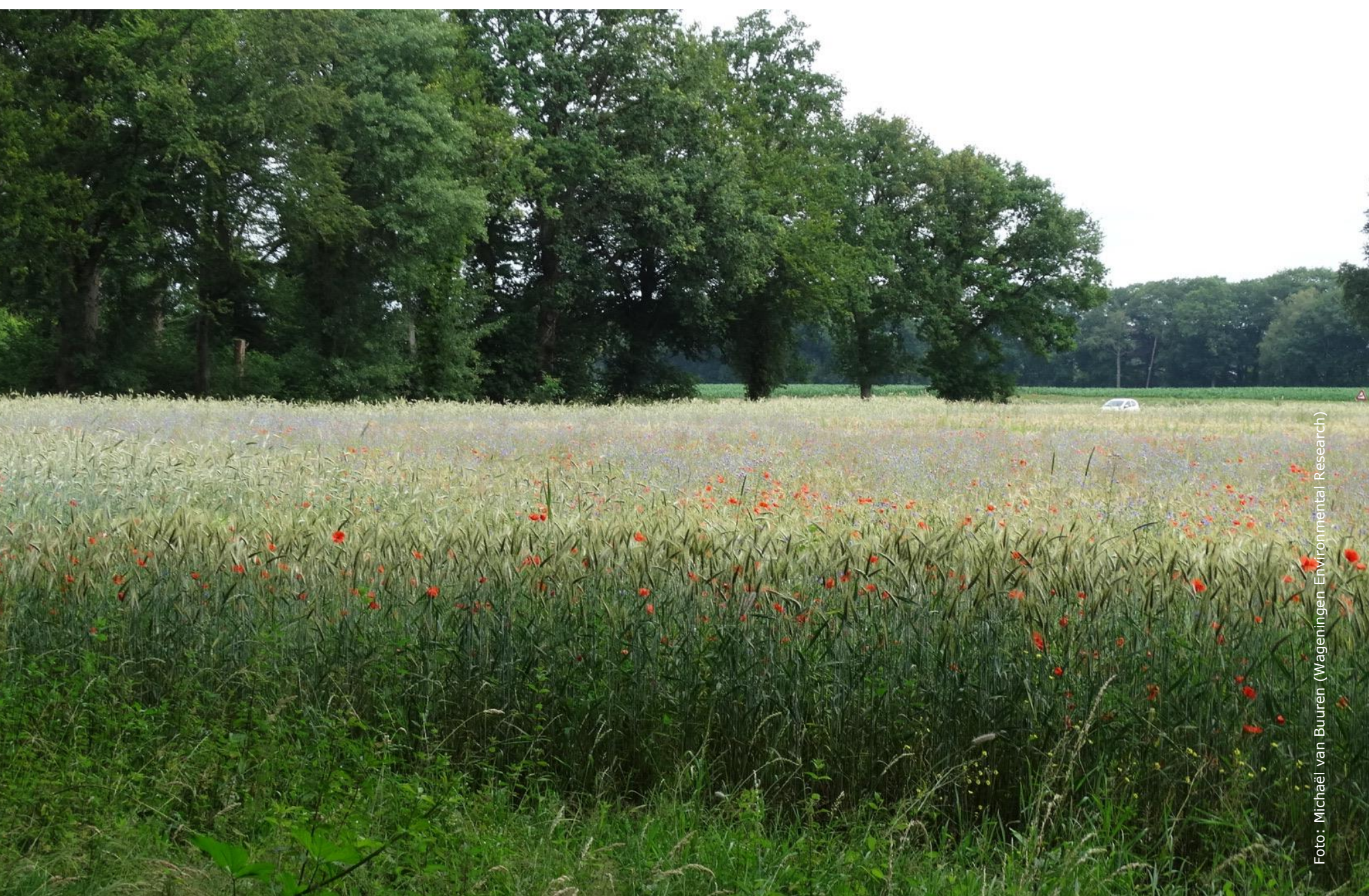




\section{$4 \quad$ Advies en vervolg}

Integrale gebiedsplanning met respect voor het natuurlijk systeem is complex. Er is een veelheid aan beleidsambities, die veelal sectoraal zijn ingestoken, met verschillende tijd horizonten en waarin meestal geen rekening is gehouden met het natuurlijk systeem. Het is voor publieke en private partijen in gebieden een schier onmogelijke opgave om dat te integreren en daar 'chocolade' van te maken.

Op basis van voorgaande analyse komen we tot een advies om een methodiek te ontwikkelen voor een integrale gebiedsplanning met respect voor het natuurlijk systeem en waarin de vraag 'hoe doe je dat' centraal staat. Die methodiekontwikkeling is geen bureaustudie, maar in een 'learning by doing' proces, samen met publieke en mogelijk ook private spelers in het gebied en kennispartijen om lessen vast te leggen, te veralgemeniseren en voor support van data.

Dit is mensenwerk. Mensen verschillen, niet alleen wat betreft de inhoudelijke werkvelden maar ook qua vermogens om dwarsverbanden te leggen, in tijdsdimensies te denken, in ruimtelijke verbeeldingskracht, geheugen enz. In het proces behoeft dat aandacht, en maatwerk hulpmiddelen zoals visualisaties daarin de dialoog bevorderen.

De overvloed aan data maken keuzemogelijkheden eerder ondoorzichtig dan transparant. Datalabs én -portals zijn er bij alle overheden, bedrijven en kennisinstellingen. Gebruikers moeten zelf nog bepalen welke data nuttige informatie oplevert en in welke combinaties. Een nog te ontwikkelen (gebiedsgericht) datalab zou de methodiekontwikkeling met gebiedsspecifieke én op maat gemaakte generieke informatie kunnen ondersteunen. Daarnaast zouden goede bewezen voorbeelden toegankelijk gemaakt kunnen worden vanuit een 'referentie bibliotheek'. Er wordt op veel fronten en in tal van gebieden gewerkt aan de queeste die 'integrale planvorming' heet. Juist het leren van elkaar op het integrale geheel en de diverse bouwstenen daarnaar toe brengt ons samen verder

Om daadwerkelijk tot samenhang en versnelling te komen, stellen wij op basis van onze analyse een opzet voor een methodiek voor:

Een methodiek voor het ontwikkelen van integrale gebiedsplanning met respect voor het natuurlijk systeem en waarin de vraag 'hoe doe je dat?' centraal staat.

Deze aanpak bestaat uit de volgende 4 elementen:

1. Ontwikkeling en verankering van een gedeelde en gedragen samenbindende visie, op basis van een gedeeld begrip van het natuurlijk systeem.

2. Oorzaak-gevolg analyse: hoe hangen de dingen met elkaar samen en op welk niveau?

3. Integraal (wat moet) en sectoraal (om tempo te maken).

4. Ter ondersteuning daarvan zijn (zichtbare) goede voorbeelden van belang. Het 'wiel zelf uitvinden' kost veel tijd, terwijl anderen het elders misschien al hebben uitgevonden. Hoe meer goede voorbeelden je kunt overnemen hoe meer tempo je kunt maken. En hoewel nog volop in ontwikkeling, zijn er her en der zeker inspirerende voorbeelden.

Wij dagen de partijen in het gebied dan ook uit om de lessen die getrokken zijn in deze preverkenning op te pakken en gezamenlijk verder te brengen. Hiermee zal de 8RHK ook zeker één van de potentiële goede voorbeelden worden van integrale planvormingen de ontwikkelingen in de regio versterkt en geborgd worden. 


\section{Handelingsperspectief en vervolg}

Een dergelijke methode-ontwikkeling zal lastig binnen bestaande werkwijzen passen. Om de urgentie te onderschrijven, ontwikkelruimte te creëren en de ontwikkelde methodiek ook daadwerkelijk toe te gaan passen is een gezamenlijke opdracht nodig van de bestuurders. Het is belangrijk dat het proces begint bij het bestuurlijk ondersteunen van de gezamenlijkheid en de keuze voor het leidend maken van de natuurlijke processen (je zou het gidsprincipes kunnen noemen).

Dit betekent niet dat bestaande processen en trajecten volledig herzien moeten worden, maar een herijking en ondersteunende stappen zijn gewenst -ten gunste van een gezamenlijke basis alsmede van een gezamenlijk perspectief en opmaat naar betere synergie en oplossen van potentiële frictiepunten.

Het verdient de aanbeveling een start te maken op basis van concrete casuïstiek met een gedeeld gevoel van urgentie. De droogteaanpak Achterhoek lijkt daarvoor zeer geschikt. Niet alleen vanwege de duidelijke verbinding tussen de korte acties en de lange termijn strategie, maar omdat de klimaateffecten ook direct samenhangen met het natuurlijk systeem, én met de voedsel- en landbouwtransitie en het belang van biodiversiteit. De regio, het waterschap en provincie Gelderland hebben al stappen gezet in die methodiek ontwikkeling. In de volgende fase zouden ze ook de overige elementen verder kunnen uitwerken: de oorzaak-gevolganalyse, de procesmatige uitwerking in integraal wat moet en sectoraal wat kan en het opbouwen van een goed referentiekader.

Tenslotte is het relevant voor alle partijen om te weten dat het gaat om een gezamenlijke zoektocht en waarin een scherp verwachtingenmanagement een belangrijke factor is om partijen in het proces aan boord te houden. Voorop staat in dat verwachtingenmanagement is dat de weg er naar toe niet eenvoudig zal zijn, maar de resultaten, de kwaliteit, effectiviteit en toekomstbestendigheid uiteindelijk zich dubbel en dwars terug zullen verdienen. Op naar een grenzeloze 8RHK. 


\section{Literatuur}

ABDTOPConsult (2021), Kiezen en Delen - Advies van de Studiegroep Ruimtelijke inrichting Landelijk Gebied, Algemene Bestuursdienst -Ministerie van Binnenlandse Zaken en Koninkrijkszaken

Baptist, M., van Hattum, T., Reinhard, S., van Buuren, M., de Rooij, B., Hu, X., van Rooij, S., Polman, N., van den Burg, S., Piet, G., Ysebaert, T., Walles, B., Veraart, J., Wamelink, W., Bregman, B., Bos, B., \& Selnes, T. (2019), Een natuurlijke toekomst voor Nederland in 2120. Wageningen University \& Research.

Bavel, B. van, Hardeman, S., Rijpma, A., (2019), Vervolgstappen voor integrale welvaartsmeting, ESB, 104(4772S)

CBS (2021), Meer verhuizingen naar regio's buiten de randstad https://www.cbs.nl/nl-nl/nieuws/2021/08/meerverhuizingen-naar-regio-s-buiten-de-randstad

CBS (2020), Monitor Brede Welvaart \& de Sustainable Development Goals 2020

Coninx, I., Bentz, J., Michalek, G. \& de Rooij, B. (2018), How to become a resilience chef and avoid disasters. PLACARD project, FC.ID, Lisbon

Coninx, I., Bentz, J., Michalek, G., \& de Rooij, L. L. (2020), Stories for Action. Web publication/site https://www.placard-network.eu/stories-for-action/

Erisman, J. W., Strootman, B. (2021), Naar een ontspannen Nederland -Hoe het oplossen van de stikstofproblematiek via een ruimtelijke benadering een hefboom kan zijn voor het aanpakken van andere grote opgaven en zo een nieuw perspectief kan opleveren voor het landelijk gebied

Global Commission on the Economy and Climate (GCEC), 2016. The New Climate Economy

$H+N+S$ (2021), Het Watersysteem van de Achterhoek-Typering, problemen en toekomstperspectief, beeldverslag workshops Aanpak Droogte Achterhoek

Mang P., Reed B. (2012), Regenerative Development and Design. In: Meyers R.A. (eds) Encyclopedia of Sustainability Science and Technology. Springer, New York, NY. https://doi.org/10.1007/978-1-4419-0851-3_303

Ministerie van Binnenlandse Zaken en Koninkrijksrelaties (2020), Nationale omgevingsvisie (NOVI)

Nesshöver, C., Assmuth, T., Irvine, K., Rusch, G., Waylen, K., Delbaere, B., Haase, D., Jones-Walters, L., Keune, H., Kovacs, E., Krauze, K., Külvik, M.,Rey, F., Dijk, J.van, Vistad, O., Wilkinson, M., Wittmer, H. (2017), The science, policy and practice of nature-based solutions: An interdisciplinary perspective, Science of The Total Environment, Volume 579, 2017, Pages 1215-1227,

Otto, I., Donges, J., Cremades, R., Bhowmik, A., Hewitt, R., Lucht, W., Rockström, J., Allerberger, F, McCaffrey, M., Doe, S., Lenferna, A., Vuuren, D. van, Schnellnhuver, H. (2020), Social tipping dynamics for stabilizing Earth's climate by 2050, in: Proceedings of the National Academy of Sciences Feb 2020, 117 (5) 23542365; DOI: 10.1073/pnas.1900577117

PBL (2021), Grote opgaven in een beperkte ruimte. Ruimtelijke keuzes voor een toekomstbestendige leefomgeving. Den Haag: Planbureau voor de Leefomgeving.

PBL (2021), Naar een uitweg uit de stikstofcrisis. Overwegingen bijeen integrale, effectieve en juridisch houdbare aanpak, Den Haag: Planbureau voor de Leefomgeving 
Roggema, R., Vermeend, T., Dobbelsteen, A. (2012), Incremental Change Transition or Transformation? Optimising Change Pathways for Climate Adaptation in Spatial Planning. Sustainability. 4. 10.3390/su4102525.

Rooij, L.L. de, Sterk, M., Meij, M. van, Hu, X., Voskamp, I.M., Timmermans, W. (2021), Klimaatrobuuste beek(dal)landschappen Noordoost Brabant: in perspectief 2050, Wageningen Environmental Research

Rooij, S. van, Timmermans, W., Roosenschoon, O., Keesstra, S., Sterk, M., Pedroli, B. (2021), Landscape-based visions as powerful boundary objects in spatial planning: Lessons from three Dutch projects. Land, 10(1), 1-14. [16]. https://doi.org/10.3390/land10010016

Skilbeck, M., Hes, D., Plessis, C. du (2016), Designing for hope: pathways to regenerative sustainability. Environ Dev Sustain 18, 311-312 (2016). https://doi.org/10.1007/s10668-015-9699-x

Straalen, F. van (2012), The concept of integration in spatial planning: an, AESOP $26^{\text {th }}$ Annual Congress

Tisma A. and Meijer J. (2018), Lessons learned from spatial planning in the Netherlands. In support of integrated landscape initiatives, globally. PBL Netherlands Environmental Assessment Agency, The Hague 


\section{Verantwoording gebruikte geodata}

\section{Natuurlijk basissysteem}

- Wageningen Environmental Research, Geomorfologische kaart Nederland (GMK2019)

- INSPIRE-WMS Informationssystem Geologische Karte von Nordrhein-Westfalen ISGK100 (2020)

- Top250 Nederland 2019

- Top50 Nederland 2019

- GeoBasis-DE / BKG -DLM250 (2020)

\section{Themakaarten}

Kwel en inzijging:

Natuurnetwerk:

Stikstofdepositie:

Recreatie:

Grondeigendom:

Cultuurhistorie:

Landgoederen:

Energie:

Wijktypolgie:

Bedrijventerreinen:

Droogte:

Droogteschade:
Klimaateffectatlas (www.klimaateffectatlas.nl) [Deltares 2016 NWM] Open data Gelderland (opendata.gelderland.nl) [Provincie Gelderland]

Atlas van de Regio (www.atlasvanderegio.nl) [PBL/RIVM]

BORIS50

Atlas van de Regio (www.atlasvanderegio.nl ) [PBL/Kadaster]

Open data Gelderland (opendata.gelderland.nl) [Provincie Gelderland] Open data Gelderland (opendata.gelderland.nl) [Provincie Gelderland]

RES Achterhoek [Liander/TenneT]

Klimaateffectatlas (www.klimaateffectatlas.nl) [HvA/Tauw]

Open data Gelderland (opendata.gelderland.nl) [Provincie Gelderland]

Klimaateffectatlas (www.klimaateffectatlas.nl) [Deltares NWM]

Wageningen Environmental Research [LHM/Agricom] 


\section{Bijlagen}

Bijlage 1 Geraadpleegde analyses, plannen en processen

\begin{tabular}{|c|c|c|c|c|}
\hline & Titel/Project naam/Document & Sectoren/Thema & Niveau & $\begin{array}{l}\text { Ruimtelijke } \\
\text { vertaling }\end{array}$ \\
\hline 1 & Nationale Omgevingsvisie & Multi & Nationaal & ja \\
\hline 2 & $\begin{array}{l}\text { Droogtetafel landelijk feb-april } \\
2019\end{array}$ & Klimaat & Nationaal & nee \\
\hline 3 & $\begin{array}{l}\text { Kennis- en innovatieagenda } \\
\text { landbouw, water, voedsel } 2020- \\
2023\end{array}$ & Landbouw & Nationaal & nee \\
\hline 4 & $\begin{array}{l}\text { Actieprogramma } \\
\text { klimaatadaptieve landbouw 2019- } \\
2030\end{array}$ & Landbouw, klimaat & Nationaal & nee \\
\hline 5 & Klimaatakkoord & Klimaat & Nationaal & nee \\
\hline 6 & Panorama Nederland & $\begin{array}{l}\text { Klimaat, landbouw, } \\
\text { energietransitie }\end{array}$ & Nationaal & ja \\
\hline 7 & $\begin{array}{l}\text { Brede Maatschappelijke } \\
\text { heroverwegingen, Klaar voor } \\
\text { klimaatverandering 2019-2020 }\end{array}$ & Klimaat & Nationaal & nee \\
\hline 8 & $\begin{array}{l}\text { Ambitiedocument Nederland } \\
\text { Natuur positief } 2019-2030\end{array}$ & Klimaat & Nationaal & nee \\
\hline 9 & $\begin{array}{l}\text { Maatregelen op de kaart NMI } \\
\text { agro (DAW) 2017-2019 }\end{array}$ & Klimaat, landbouw & Nationaal & ja \\
\hline 10 & $\begin{array}{l}\text { Colander, landschapsgestuurde } \\
\text { klimaatadaptatie (WUR in } \\
\text { opdracht van LNV) 2019-2021 }\end{array}$ & Klimaat & Nationaal & nee \\
\hline 11 & Nederland in 2120 & Multi & Nationaal & ja \\
\hline 12 & Care adaptatiemaatregelen 2014 & Klimaat & Nationaal & nee \\
\hline 13 & $\begin{array}{l}\text { Nationaal programma } \\
\text { landbouwbodems }\end{array}$ & Landbouw & Nationaal & nee \\
\hline 14 & $\begin{array}{l}\text { Kaderrichtlijn Water (KRW) 2019- } \\
2027\end{array}$ & $\begin{array}{l}\text { klimaat, water, } \\
\text { landbouw }\end{array}$ & Nationaal & nee \\
\hline 15 & $\begin{array}{l}\text { Deltaplan Ruimtelijke Adaptatie } \\
2017-2020\end{array}$ & klimaat & Nationaal & nee \\
\hline 16 & Deltaplan Agrarisch Waterbeheer & Landbouw, klimaat & Nationaal & ja \\
\hline 17 & $\begin{array}{l}\text { Grondwater afhankelijke natuur } \\
\text { in Hoog Nederland (effecten van } \\
\text { onttrekkingen op natuur tijdens } \\
\text { droogte 2018), Concept plan van } \\
\text { aanpak. 2019-2020 }\end{array}$ & Klimaat & Interprovinciaal & nee \\
\hline
\end{tabular}




\begin{tabular}{|c|c|c|c|c|}
\hline 18 & $\begin{array}{l}\text { Maatregelenprogramma } \\
\text { Zoetwatervoorziening Oost } \\
\text { Nederland 2016-2027 }\end{array}$ & Klimaat & Interprovinciaal & ja \\
\hline 19 & $\begin{array}{l}\text { Appèl waterpartners Oost- } \\
\text { Nederland, 'Andere koers en } \\
\text { gezamenlijke agenda nodig' nov } \\
\text { 2019- }\end{array}$ & Klimaat & Interprovinciaal & nee \\
\hline 20 & $\begin{array}{l}\text { Oost-Nederland: gebiedsagenda } \\
\text { Oost-Nederland 2019-2040 }\end{array}$ & Klimaat & Interprovinciaal & nee \\
\hline 21 & $\begin{array}{l}\text { Oost Nederland onderzoek naar } \\
\text { de opgaven en kansen maart } \\
2018\end{array}$ & Multi & Interprovinciaal & ja \\
\hline 22 & Omgevingsvisie Gaaf Gelderland & Multi & Provinciaal & ja \\
\hline 23 & $\begin{array}{l}\text { Actieplan Natuurinclusieve } \\
\text { Landbouw Gelderland }\end{array}$ & Landbouw & Provinciaal & nee \\
\hline 24 & Verrijkende landbouw & Landbouw & Provinciaal & nee \\
\hline 25 & $\begin{array}{l}\text { Vitaal en diverse bos - } \\
\text { uitvoeringsprogramma Bomen en } \\
\text { Bos }\end{array}$ & Natuur & Provinciaal & \\
\hline 26 & Gelders Klimaatplan 2021-2030 & Klimaat & Provinciaal & nee \\
\hline 27 & $\begin{array}{l}\text { Statenbrief: Contouren Gelderse } \\
\text { Maatregelen Stikstof 2019-2023 }\end{array}$ & $\begin{array}{l}\text { Landbouw, mobiliteit en } \\
\text { circulair bouwen }\end{array}$ & Provinciaal & nee \\
\hline 28 & $\begin{array}{l}\text { Provinciale verkenning } \\
\text { Gelderse maatregelen stikstof } \\
\text { 2020-2025: Concept } \\
\text { uitvoeringsagenda Veluwe, } \\
\text { Rijntakken en Achterhoek } \\
\text { juni } 2020\end{array}$ & $\begin{array}{l}\text { Natuur, mobiliteit, } \\
\text { landbouw, industrie, } \\
\text { bouw. }\end{array}$ & Provinciaal & ja \\
\hline 29 & $\begin{array}{l}\text { Droogte (juli2019-) } \\
\text { Verkenning aanpak droogte } \\
\text { Achterhoek }\end{array}$ & Klimaat & Provinciaal & nee \\
\hline 30 & Provinciale verkenning stikstof & Stikstof & Provinciaal & nee \\
\hline 31 & $\begin{array}{l}\text { Natuur en landschap (juli 2019- } \\
\text { 2022) }\end{array}$ & Natuur en landschap & Provinciaal & nee \\
\hline 32 & Gelders Energie Akkoord GEA & Energie & Povinciaal & \\
\hline 33 & $\begin{array}{l}\text { Omgevingsvisie Gaaf Gelderland } \\
\text { (2018) en Omgevingsverordening }\end{array}$ & Multi & Provinciaal & $\mathrm{Ja}$ \\
\hline 34 & $\begin{array}{l}\text { Ontwerp-actualisatieplan } \\
\text { Omgevingsverordening (22-09- } \\
2020 \text { ) }\end{array}$ & Multi & Provinciaal & ja \\
\hline 35 & $\begin{array}{l}\text { Omgevingsverordening } \\
\text { Gelderland (concept) samenhang } \\
\text { met omgevingsvisie }\end{array}$ & Multi & Provinciaal & ja \\
\hline 36 & $\begin{array}{l}\text { N2000-herstelmaatregelen } \\
(2020-2021)\end{array}$ & Natuur & Provinciaal & ja \\
\hline 37 & N2000-Beheerplannen & Natuur & Provinciaal & ja \\
\hline
\end{tabular}




\begin{tabular}{|c|c|c|c|c|}
\hline 38 & $\begin{array}{l}\text { Rapportage Circulaire Atlas } \\
\text { Gelderland (Juli 2019) }\end{array}$ & Circulaire economie & Provinciaal & ja \\
\hline 39 & $\begin{array}{l}\text { Uitvoeringsprogramma } \\
\text { gebiedsdossiers } \\
\text { grondwaterbeschermingsgebieden } \\
\text { Gelderland } 2019-2025\end{array}$ & Landbouw, water & Provinciaal & nee \\
\hline 40 & Waterwijs Boeren Gelderland & Landbouw, water & Provinciaal & nee \\
\hline 41 & $\begin{array}{l}\text { Koersnotitie Agrifood (voorheen } \\
\text { Koersnotitie Natuurinclusieve } \\
\text { Land- en Tuinbouw) } 2020\end{array}$ & Landbouw & Provinciaal & nee \\
\hline 42 & $\begin{array}{l}\text { Onderzoek monitoring } \\
\text { klimaatadaptatiemaatregelen } 5 \\
\text { casussen (stedelijk gebied) 2019- } \\
2029\end{array}$ & Klimaat & Provinciaal & nee \\
\hline 43 & $\begin{array}{l}\text { Gebiedsgenese uitwerken voor } \\
\text { een deel van de Achterhoek } 2019\end{array}$ & Water & Provinciaal & nee \\
\hline 44 & $\begin{array}{l}\text { Synthese Beleidsevaluaties } \\
\text { Droogte } 2018\end{array}$ & Klimaat & Provinciaal & nee \\
\hline 45 & $\begin{array}{l}\text { Bestuursovereenkomst } \\
\text { Nitraatrichtlijn 2017-2021 }\end{array}$ & Landbouw & Provinciaal & nee \\
\hline 46 & $\begin{array}{l}\text { GEA tafel landbouw en } \\
\text { landgebruik (trekker GMNF) }\end{array}$ & Klimaat, landbouw & Provinciaal & nee \\
\hline 47 & $\begin{array}{l}\text { Verrijkende landbouw in } \\
\text { Gelderland } 2019-2020\end{array}$ & Klimaat, landbouw & Provinciaal & nee \\
\hline 48 & $\begin{array}{l}\text { Klimaatadaptatie in de praktijk } \\
2020-2023\end{array}$ & $\begin{array}{l}\text { klimaat, landbouw, } \\
\text { natuur }\end{array}$ & Provinciaal & nee \\
\hline 49 & $\begin{array}{l}\text { Klimaatadaptatie droge rurale } \\
\text { zandgronden Gelderland } 2011\end{array}$ & Klimaat & Provinciaal & nee \\
\hline 50 & Klimaatatelier Gelderland & Klimaat & Provinciaal & ja \\
\hline 51 & $\begin{array}{l}\text { Gelderse Maatregelen Stikstof } \\
\text { update december } 2020\end{array}$ & Landbouw, natuur & Provinciaal & nee \\
\hline 52 & $\begin{array}{l}\text { Droogte onderzoek } \\
\text { zandprovincies feb 2019- juni } \\
2020\end{array}$ & Klimaat & Provinciaal & nee \\
\hline 53 & $\begin{array}{l}\text { Provincie: Realiseren GNN, } \\
\text { Gelders natuurnetwerk }\end{array}$ & Natuur & Provinciaal & ja \\
\hline 54 & $\begin{array}{l}\text { Visie strategische } \\
\text { drinkwatervoorraden (ASV) }\end{array}$ & Water & Provinciaal & nee \\
\hline 55 & $\begin{array}{l}\text { Klimaatstrategie Waterschap Rijn } \\
\text { Ijssel 2018-2021 }\end{array}$ & Klimaat & Bovenregionaal & nee \\
\hline 56 & $\begin{array}{l}\text { Waterbeheerplan 2016-2021 Rijn } \\
\text { en IJssel }\end{array}$ & Water & Bovenregionaal & \\
\hline 57 & $\begin{array}{l}\text { Visie op voorraadbeheer } \\
\text { grondwaterbeheer Waterschap } \\
\text { Rijn IJssel, nav Beleidstafel } \\
\text { Droogte (in voorbereiding) } 2019\end{array}$ & Klimaat & Bovenregionaal & nee \\
\hline 58 & $\begin{array}{l}\text { Bestuursakkoord Waterschap Rijn } \\
\text { IJssel 2019-2023, 'Samen een } \\
\text { duurzame toekomst creëren' }\end{array}$ & Klimaat & Bovenregionaal & nee \\
\hline
\end{tabular}




\begin{tabular}{|c|c|c|c|c|}
\hline 59 & $\begin{array}{l}\text { Blauwe Omgevingsvisie Vallei en } \\
\text { Veluwe (BOVI 2050) }\end{array}$ & Klimaat & Bovenregionaal & ja \\
\hline 60 & $\begin{array}{l}\text { Grondwateragenda Rijn-Oost } \\
\text { (2030) }\end{array}$ & Klimaat & Bovenregionaal & nee \\
\hline 61 & RES Achterhoek (juli 2019-2022) & Energie & Regionaal & $\mathrm{Ja}$ \\
\hline 62 & Aanpak droogte Achterhoek & $\begin{array}{l}\text { Klimaat (landbouw, } \\
\text { natuur, biodiversiteit) }\end{array}$ & Regionaal & Nee \\
\hline 63 & $\begin{array}{l}\text { Verdeel(de) } \\
\text { verantwoordelijkheid: Een } \\
\text { reflectie op samenwerking bij de } \\
\text { aanpak van droogte in de } \\
\text { Achterhoek }\end{array}$ & Klimaat & Regionaal & Nee \\
\hline 64 & $\begin{array}{l}\text { Visie Achterhoek } 2030 \text { en } \\
\text { uitvoeringsplannen: Achterhoek } \\
2030 \text { (april 2018-2030) }\end{array}$ & Multi & Regionaal & ja \\
\hline 65 & $\begin{array}{l}\text { Lopende projectenAchterhoek } \\
\text { Visie } 2030(09-2020) \\
\text { - SmartHub }\end{array}$ & Werken & Regionaal & nee \\
\hline 66 & $\begin{array}{l}\text { Lopende projectenAchterhoek } \\
\text { Visie } 2030(09-2020) \\
\text { - Achterhoek } 2020 \text { Jong }\end{array}$ & Werken & Regionaal & nee \\
\hline 67 & $\begin{array}{l}\text { Lopende projectenAchterhoek } \\
\text { Visie } 2030(09-2020) \\
\text { - Vouchers circulaire economie } \\
\text { (tot 2020) }\end{array}$ & Economie & Regionaal & nee \\
\hline 68 & $\begin{array}{l}\text { Lopende projectenAchterhoek } \\
\text { Visie } 2030(09-2020) \\
\text { - Digitale beleving - TOP's (tot } \\
\text { 2020) }\end{array}$ & Economie & Regionaal & nee \\
\hline 69 & $\begin{array}{l}\text { Lopende projectenAchterhoek } \\
\text { Visie } 2030(09-2020) \\
\text {-Incubator De Steck (tot 2021) }\end{array}$ & Werken & Regionaal & nee \\
\hline 70 & $\begin{array}{l}\text { Lopende projectenAchterhoek } \\
\text { Visie } 2030(09-2020) \\
\text { - MKB-deal (tot 2022) }\end{array}$ & Economie & Regionaal & nee \\
\hline 71 & $\begin{array}{l}\text { Lopende projectenAchterhoek } \\
\text { Visie } 2030(09-2020) \\
\text { - SMAAS Achterhoek (tot 2021) }\end{array}$ & $\begin{array}{l}\text { Mobiliteit en } \\
\text { bereikbaarheid }\end{array}$ & Regionaal & nee \\
\hline 72 & $\begin{array}{l}\text { Lopende projectenAchterhoek } \\
\text { Visie } 2030(09-2020) \\
\text { - Onderzoek tweede fase N18 (tot } \\
\text { 2020) }\end{array}$ & $\begin{array}{l}\text { Mobiliteit en } \\
\text { bereikbaarheid }\end{array}$ & Regionaal & nee \\
\hline 73 & $\begin{array}{l}\text { Lopende projectenAchterhoek } \\
\text { Visie } 2030 \text { (09-2020) } \\
\text { - Vruchtbare Kringloop (VKA) (tot } \\
\text { 2022) }\end{array}$ & Landbouw & Regionaal & nee \\
\hline 74 & $\begin{array}{l}\text { Lopende projectenAchterhoek } \\
\text { Visie } 2030 \text { (09-2020) } \\
\text { - Scholder an Scholder - } \\
\text { Achterhoek in Beweging (tot } \\
\text { 2020) }\end{array}$ & Zorg en leefbaarheid & Regionaal & nee \\
\hline 75 & $\begin{array}{l}\text { IBP Vitaal Platterland (2019- } \\
2021 \text { ) } \\
\text { De Achterhoek, Scho(onst)e regio } \\
\text { van Nederland } \\
\text { Voorstel voor programma IBP- } \\
\text { Vitaal platteland Achterhoek dd } \\
15 \text { mei } 2019\end{array}$ & Landbouw & Regionaal & nee \\
\hline 76 & $\begin{array}{l}\text { Achterhoek als } \\
\text { experimenteerregio agro } \\
\text { innovatieregio (2019-) }\end{array}$ & Landbouw & Regionaal & nee \\
\hline
\end{tabular}




\begin{tabular}{|c|c|c|c|c|}
\hline 77 & $\begin{array}{l}\text { Concept Regionale } \\
\text { Energiestrategie Achterhoek } 16 \\
\text { juni } 2020\end{array}$ & Energie & Regionaal & ja \\
\hline 78 & $\begin{array}{l}\text { Impact van concept RES } \\
\text { scenario's op de elektriciteits- en } \\
\text { gasinfrastructuur RES regio } \\
\text { Achterhoek }\end{array}$ & Energie & Regionaal & ja \\
\hline 79 & $\begin{array}{l}\text { Plan van aanpak RES } 1.0 \\
\text { Achterhoek }\end{array}$ & Energie & Regionaal & nee \\
\hline 80 & Klimaatrobuuste Achterhoek & $\begin{array}{l}\text { Klimaat (landbouw, } \\
\text { natuur, water, bodem) }\end{array}$ & Regionaal & nee \\
\hline 81 & $\begin{array}{l}\text { Gebiedsagenda Achterhoek: } \\
\text { Ruimte voor innovatie, Groeien in } \\
\text { kwaliteit ( } 31 \text { maart 2020) }\end{array}$ & Multi & Regionaal & nee \\
\hline 83 & $\begin{array}{l}\text { Interbestuurlijk Programma (IBP) } \\
\text { - Vitaal Platteland Achterhoek } \\
(2018-2022)\end{array}$ & Multi & Regionaal & ja \\
\hline 84 & Vruchtbare Kringloop Achterhoek & Landbouw & Regionaal & nee \\
\hline 85 & $\begin{array}{l}\text { Platform Landbouw, natuur en } \\
\text { water (LNW) 2020-2023 }\end{array}$ & water & Regionaal & nee \\
\hline 86 & $\begin{array}{l}\text { Innovatie coöperatie Achterhoek } \\
2018\end{array}$ & Landbouw & Regionaal & nee \\
\hline 87 & Visie waterberaad Achterhoek+ & Water, klimaat & Regionaal & ja \\
\hline 88 & $\begin{array}{l}\text { Het Kansrijke Platteland van de } \\
\text { Achterhoek }\end{array}$ & Multi & Regionaal & ja \\
\hline 89 & $\begin{array}{l}\text { Kracht van de Achterhoek -de } \\
\text { waarde van voedselketens voor } \\
\text { de regio }\end{array}$ & Landbouw & Regionaal & nee \\
\hline 90 & $\begin{array}{l}\text { Nadere analyse vrijkomende } \\
\text { agrarische bebouwing Gelderland }\end{array}$ & Landbouw & Regionaal & ja \\
\hline 91 & Atlas van de Achterhoek & Multi & Regionaal & ja \\
\hline 92 & Achterhoek Monitor & Multi & Regionaal & $\mathrm{ja} / \mathrm{nee}$ \\
\hline 93 & $\begin{array}{l}\text { Regionaal sturings- en } \\
\text { waarderingsmodel Achterhoek } \\
\text { voor duurzame melkveehouderij } \\
\text { (Pilot GLB)2019 }\end{array}$ & Klimaat & Regionaal & nee \\
\hline 94 & $\begin{array}{l}\text { Gezamenlijke klimaateffectatlas } \\
\text { Achterhoek en Liemers } \\
\text { (gemeenten in Achterhoek en } \\
\text { Liemers en Waterschap), } \\
\text { onderdeel van Deltaplan } \\
\text { Ruimtelijke Adaptatie }\end{array}$ & Klimaat & Regionaal & ja \\
\hline 95 & $\begin{array}{l}\text { Lopende projectenAchterhoek } \\
\text { Visie } 2030(09-2020) \\
\text { - Smart Business Centre/Smart } \\
\text { Business Centre + (tot 2022) }\end{array}$ & Economie & Regionaal & nee \\
\hline 96 & $\begin{array}{l}\text { Lopende projectenAchterhoek } \\
\text { Visie } 2030(09-2020) \\
\text { - Sleutel tot een energieneutrale } \\
\text { woning (tot } 2020)\end{array}$ & Wonen & Regionaal & nee \\
\hline 97 & $\begin{array}{l}\text { Lopende projectenAchterhoek } \\
\text { Visie } 2030(09-2020) \\
\text { - Leefsamen Achterhoekse } \\
\text { woningcorporaties (tot } 2021 \text { ) }\end{array}$ & Wonen & Regionaal & nee \\
\hline 98 & $\begin{array}{l}\text { Lopende projectenAchterhoek } \\
\text { Visie } 2030 \text { (09-2020) } \\
\text { - Kunstmestvrije Achterhoek (tot } \\
2022 \text { ) }\end{array}$ & Landbouw & Regionaal & nee \\
\hline
\end{tabular}




\begin{tabular}{|c|c|c|c|c|}
\hline 99 & $\begin{array}{l}\text { Lopende projectenAchterhoek } \\
\text { Visie } 2030(09-2020) \\
\text { - Innovatiecentrum de Marke (tot } \\
2022 \text { ) }\end{array}$ & Landbouw & Regionaal & nee \\
\hline 100 & $\begin{array}{l}\text { Lopende projectenAchterhoek } \\
\text { Visie } 2030(09-2020) \\
\text { - Cirkelregio Achterhoek (tot } \\
\text { 2022) }\end{array}$ & Circulair & Regionaal & nee \\
\hline 101 & $\begin{array}{l}\text { Lopende projectenAchterhoek } \\
\text { Visie } 2030(09-2020) \\
\text { - Zuiverende kas (tot 2022) }\end{array}$ & Circulair & Regionaal & nee \\
\hline 102 & $\begin{array}{l}\text { Lopende projectenAchterhoek } \\
\text { Visie } 2030(09-2020) \\
\text { - Biogas en waterstof in } \\
\text { Bronckhorst (tot 2021) }\end{array}$ & Energie & Regionaal & nee \\
\hline 103 & $\begin{array}{l}\text { Lopende projectenAchterhoek } \\
\text { Visie } 2030(09-2020) \\
\text {-Werken aan toekomstgerichte } \\
\text { erven in de Achterhoek (tot } 2021)\end{array}$ & Leefbaarheid & Regionaal & nee \\
\hline 104 & $\begin{array}{l}\text { Lopende projectenAchterhoek } \\
\text { Visie } 2030(09-2020) \\
\text { - Zonvarken (tot 2022) }\end{array}$ & Landbouw & Regionaal & nee \\
\hline 105 & $\begin{array}{l}\text { Regiodeal Achterhoek (juli 2019- } \\
\text { 2022) }\end{array}$ & Landbouw, Wonen & Regionaal & nee \\
\hline 106 & $\begin{array}{l}\text { Visie landgoederen Baakse Beek- } \\
\text { Bronckhorst 2019-2023 }\end{array}$ & Water & Regionaal & ja \\
\hline 107 & $\begin{array}{l}\text { Lopende projectenAchterhoek } \\
\text { Visie } 2030(09-2020) \\
\text { - Zorgeloos Samenwonen in de } \\
\text { Kattenberg (tot 2024) }\end{array}$ & Wonen & Regionaal & nee \\
\hline 108 & $\begin{array}{l}\text { Lopende projectenAchterhoek } \\
\text { Visie } 2030(09-2020) \\
\text { - Zon op erf- demonstratiefase } \\
\text { (tot 2021) }\end{array}$ & Energie & Regionaal & nee \\
\hline 109 & Concept omgevingsvisies & Multi & Lokaal & ja/nee \\
\hline 110 & $\begin{array}{l}\text { Natuurlijke klimaatbuffers, } \\
\text { projecten Natuurherstel } \\
\text { Korenburgeveen en Wooldse } \\
\text { Veen } 2019-2021\end{array}$ & Klimaat & Lokaal & ja \\
\hline 111 & $\begin{array}{l}\text { Klimaatadaptatie brongebied } \\
\text { Baakse Beek, project Klimaat } \\
\text { Klaor 2014- }\end{array}$ & Klimaat & Lokaal & nee \\
\hline 112 & $\begin{array}{l}\text { Brandbrief landbouw ivm } \\
\text { drinkwaterwinning 't Klooster } \\
2019\end{array}$ & Klimaat, Landbouw & Lokaal & nee \\
\hline 113 & Onderzoeksproject DRIVER & Energie & Lokaal & ja \\
\hline 114 & $\begin{array}{l}\text { Natuurpark Kronenkamp nabij } \\
\text { Neede }(2015-2020)\end{array}$ & $\begin{array}{l}\text { Energie, Klimaat, } \\
\text { Circlaire, Biodiversiteit, } \\
\text { Woon- en leefomgeving }\end{array}$ & Lokaal & ja \\
\hline 115 & $\begin{array}{l}\text { Agenda - waterwingebied - 't } \\
\text { Klooster } 2011\end{array}$ & $\begin{array}{l}\text { Klimaat, water, } \\
\text { landbouw }\end{array}$ & Lokaal & ja \\
\hline
\end{tabular}




\section{Bijlage 2 Geraadpleegde dataportals}

\begin{tabular}{|l|}
\hline Atlas van de Leefomgeving \\
\hline $\begin{array}{l}\text { Dataportal Gelderland } \\
\text { (opendata.gelderland.nl) }\end{array}$ \\
\hline $\begin{array}{l}\text { Gelderland Kaarten en Cijfers } \\
\text { https://www.gelderland.nl/Kaartenencijfers }\end{array}$ \\
\hline $\begin{array}{l}\text { Gelderland Planviewer } \\
\text { https://gldanders.planoview.nl/planoview/ }\end{array}$ \\
\hline Klimaateffectatlas \\
\hline Klimaatschadeschatter \\
\hline Atlas Natuurlijk Kapitaal \\
\hline Compendium voor de Leefomgeving \\
\hline Achterhoek Monitor \\
\hline Geodata RIVM \\
\hline Nationale Energieatlas \\
\hline Geoportal.NRW \\
\hline
\end{tabular}




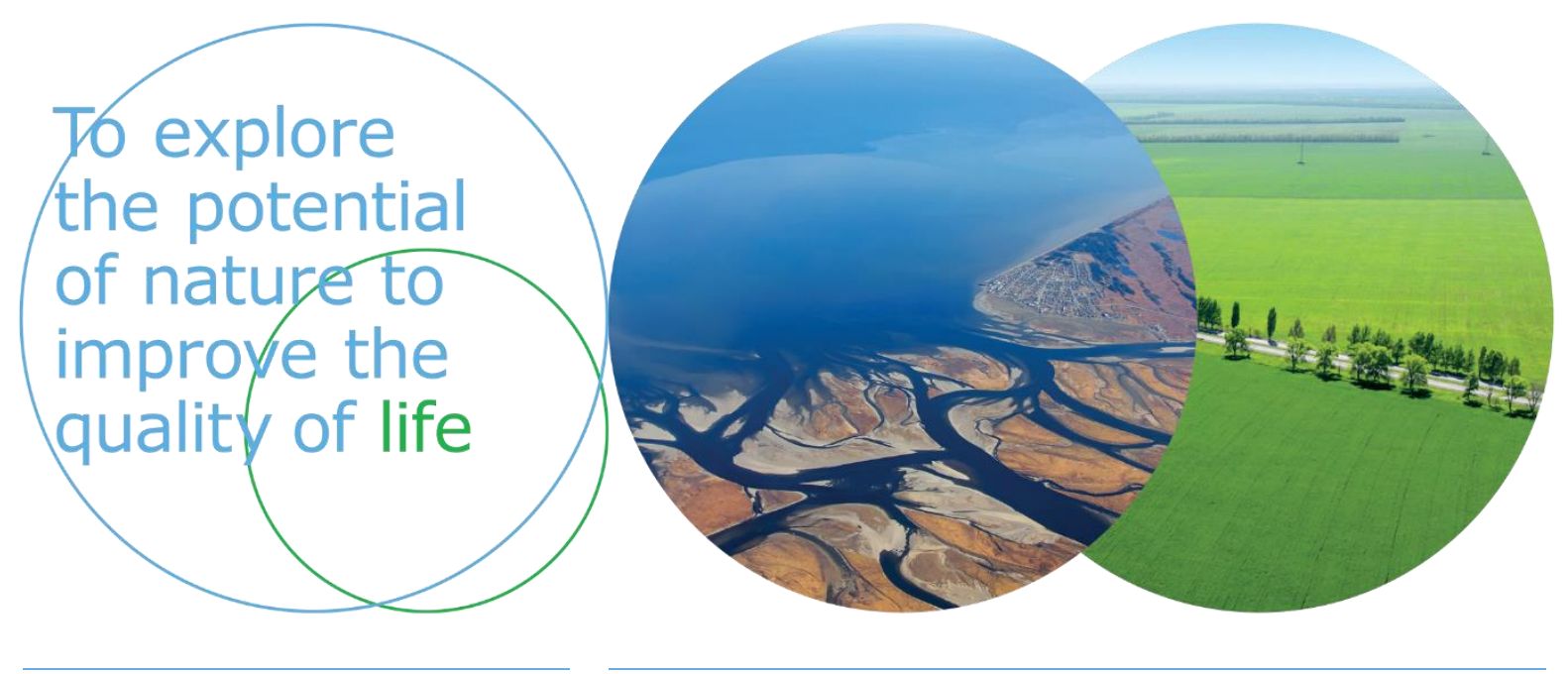

Wageningen Environmental Research Postbus 47

6700 AA Wageningen

T 0317480700

www.wur.nl/environmental-research

Wageningen Environmental Research
De missie van Wageningen University \& Research is 'To explore the potential of nature to improve the quality of life'. Binnen Wageningen University \& Research bundelen Wageningen University en gespecialiseerde onderzoeksinstituten van Stichting Wageningen Research hun krachten om bij te dragen aan de oplossing van belangrijke vragen in het domein van gezonde voeding en leefomgeving. Met ongeveer 30 vestigingen, 6.800 medewerkers ( $6.000 \mathrm{fte}$ ) en 12.900 studenten behoort Wageningen University \& Research wereldwijd tot de aansprekende kennisinstellingen binnen haar domein. De integrale benadering van de vraagstukken en de samenwerking tussen verschillende disciplines vormen het hart van de unieke Wageningen aanpak. 